\title{
The Islamic Connection : Critical Perspectives on the Religious Discourse in Russia's Foreign Policy Towards the Islamic World during Vladimir Putin's Presidency, 2000-2008
}

by

Denis Giroux, B.A.(Hon.)

\author{
A thesis submitted to \\ the Faculty of Graduate Studies and Research \\ in partial fulfilment of the \\ requirements for the degree of
}

Master of Arts

Institute of European, Russian and Eurasian Studies

\author{
Carleton University \\ Ottawa, Ontario
}

January 2011

(C2011, D. Giroux 
Library and Archives

Canada

Published Heritage Branch

395 Wellington Street Ottawa ON K1A 0N4 Canada
Bibliothèque et

Archives Canada

Direction du

Patrimoine de l'édition

395 , rue Wellington

Ottawa ON K1A ON4

Canada
Your file Votre référence

ISBN: 978-0-494-81653-0

Our file Notre rétérence

ISBN: 978-0-494-81653-0
NOTICE:

The author has granted a nonexclusive license allowing Library and Archives Canada to reproduce, publish, archive, preserve, conserve, communicate to the public by telecommunication or on the Internet, loan, distribute and sell theses worldwide, for commercial or noncommercial purposes, in microform, paper, electronic and/or any other formats.

The author retains copyright ownership and moral rights in this thesis. Neither the thesis nor substantial extracts from it may be printed or otherwise reproduced without the author's permission.
AVIS:

L'auteur a accordé une licence non exclusive permettant à la Bibliothèque et Archives Canada de reproduire, publier, archiver, sauvegarder, conserver, transmettre au public par télécommunication ou par l'Internet, prêter, distribuer et vendre des thèses partout dans le monde, à des fins commerciales ou autres, sur support microforme, papier, électronique et/ou autres formats.

L'auteur conserve la propriété du droit d'auteur et des droits moraux qui protège cette thèse. $\mathrm{Ni}$ la thèse ni des extraits substantiels de celle-ci ne doivent être imprimés ou autrement reproduits sans son autorisation.
In compliance with the Canadian Privacy Act some supporting forms may have been removed from this thesis.

While these forms may be included in the document page count, their removal does not represent any loss of content from the thesis.
Conformément à la loi canadienne sur la protection de la vie privée, quelques formulaires secondaires ont été enlevés de cette thèse.

Bien que ces formulaires aient inclus dans la pagination, il n'y aura aucun contenu manquant. 
Inspired by Samuel Huntington's The Clash of Civilizations, this essay shows the oft-overlooked relevance of considering the role of religious institutions in the formulation of contemporary Russian foreign policy. It is argued that this relevance stems from the Orthodox Church's long history, going back to the Byzantine Empire, of having a close relationship with the temporal state (concept of symphonia). In Russia's specific case, the interest of the Church for state affairs can be observed not only in the preimperial period, but all throughout the twentieth century. This essay enterprises to conceptualize the link between the influence of religious institutions in Russia, both the Moscow Patriarchate and the Muslim minority, and how they influence the state's foreign policy towards the Islamic world. To do so, the present essay proposes to use a poststructuralist approach centered on discourse analysis, thereby focusing the debate on the role of agency in foreign policy formulation.

Keywords: Russia, religion, poststructuralism, foreign policy, Clash of Civilizations, Islamic world 
I wish to thank Professor Andrea Chandler for having believed in me all throughout my project, and for having provided me with excellent supervision and constructive feedback.

Special thanks are due to Professors Cédric Jourde, David Grondin and Miguel de Larrinaga from the University of Ottawa who, during my first semester of doctoral studies, introduced me to theories and articles I had overlooked and proved to be important to the completion of my argument.

I also need to highlight the very useful feedback I received, in a timely fashion, from Professor Anessa Kimball of Laval University.

I am indebted to Professor David Mendeloff, who provided me with suggestions about how I should improve the numerous versions of the research proposal I submitted him in the early stages of my project.

The last version of my research proposal was much improved by the refinements recommended by Professor Piotr Dutkiewicz and my classmates from the Institute of European, Russian and Eurasian Studies, for which I am thankful.

My gratitude is extended to all the people who, at one point or another, have read my work and have provided moral and academic support towards its completion, and have otherwise supported my varied academic endeavors: Dr Jan Fedorowicz, Dr Peter Konecny, Dr Jeff Sahadeo, Yannick Veilleux-Lepage, Mark Griffiths, Etienne Boisjoli, Dan Vassiliou, Henri Proulx, Dr Matthew Mayer, and all the others who have provided me with feedback and encouragement over the last few years.

Last but not least, I would like to thank my mother, without whom all of this would not have been possible, and who gives me the assurance that my thesis will find a good reception, regardless of any of my peer reviews.

I want to take this opportunity to also thank the organizations from which I received crucial funding during my master's: the Faculty of Graduate Studies and Research at Carleton University; the Institute of European, Russian, and Eurasian Studies; the Central/Eastern European and Russian-Area Studies Bursary; the University of Ottawa; the Province of Ontario; and my nation, the Province of Quebec. 


\section{Table of Contents}

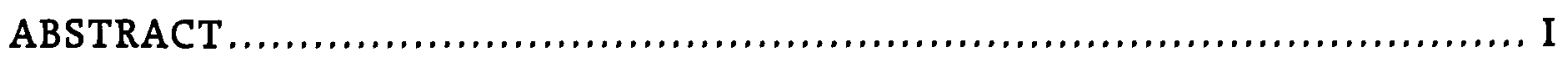

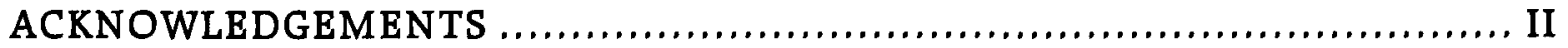

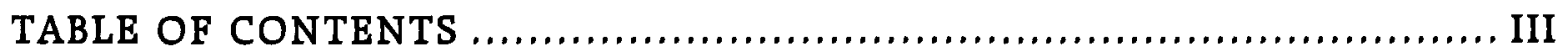

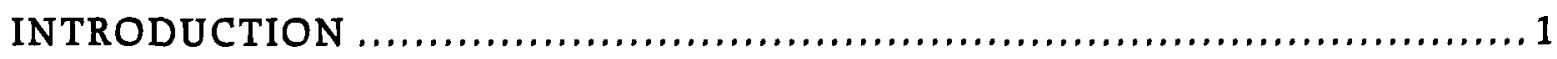

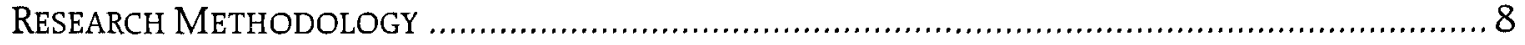

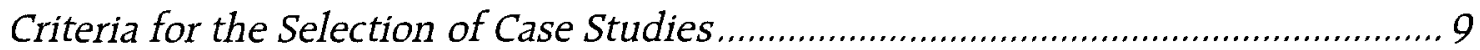

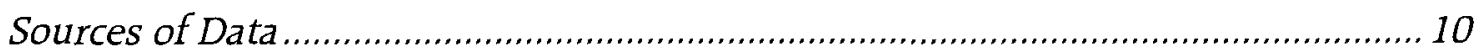

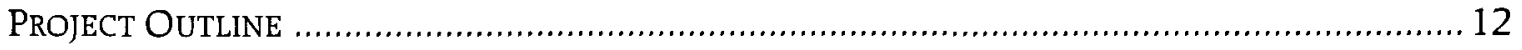

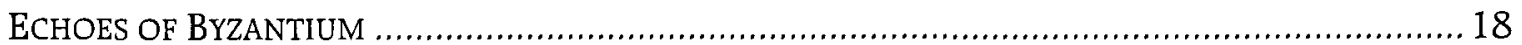

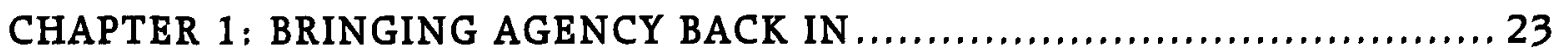

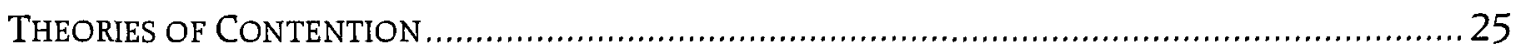

The flawed logic of "fault line conflicts" .................................................................., 26

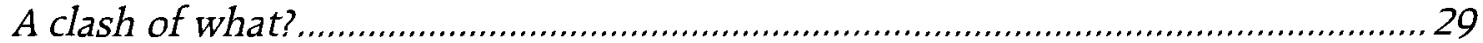

Taking It Down a Notch................................................................................. 30

Domesticating Foreign Policy ....................................................................... 34

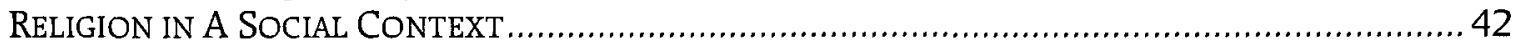

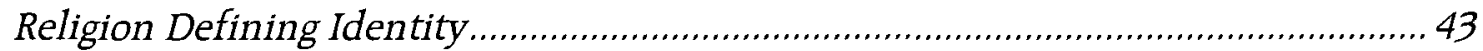

Pseudo-Religious Politics .............................................................................. 45

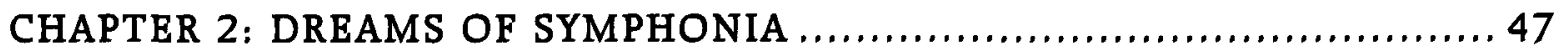

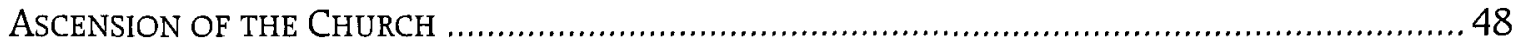

The Figures of Religious Identity ...................................................................., 48

Making the Front Pages .................................................................................. 50

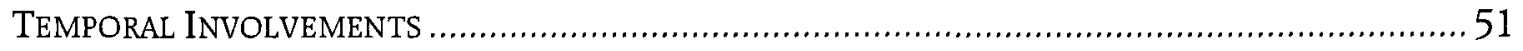

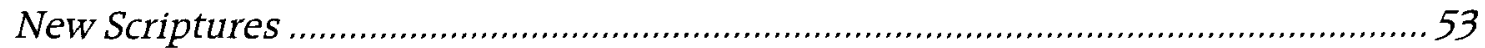

Liturgy for the People ........................................................................................... 56

The President, the Patriarch, and the Holy Ghost............................................... 58

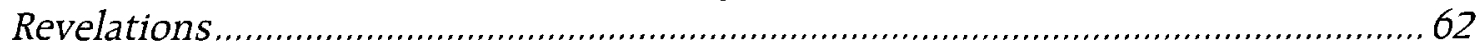

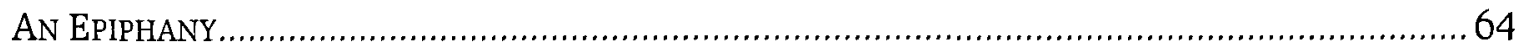




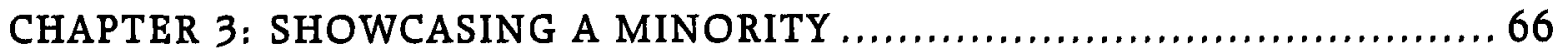

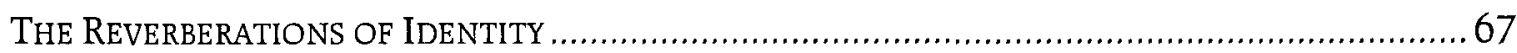

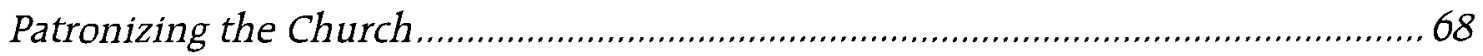

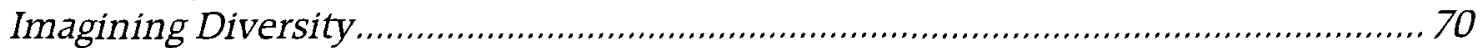

The Effects of International Socialization .............................................................. 72

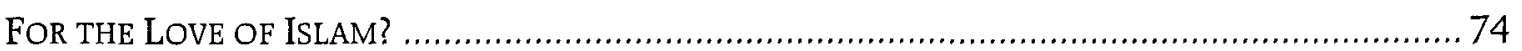

A Prophet Comes Bearing Gifts............................................................................ 74

Unread Small Print ....................................................................................... 76

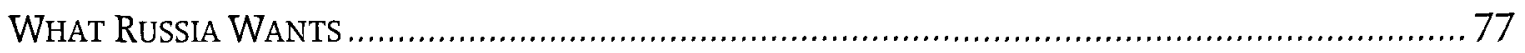

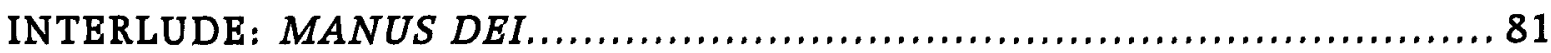

CHAPTER 4: FLIRTATIONS WITH THE HOLY KINGDOM $\ldots \ldots \ldots \ldots \ldots \ldots . \ldots 84$

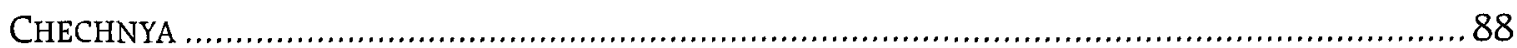

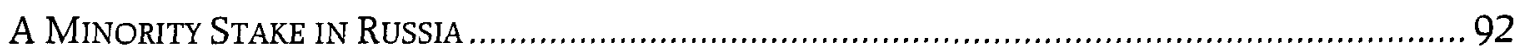

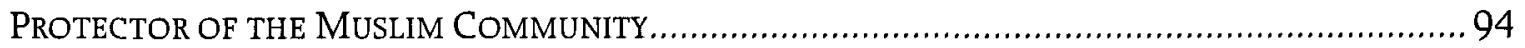

CHAPTER 5: THE CONUNDRUM OF THE ISLAMIC REPUBLIC $\ldots \ldots \ldots \ldots \ldots . \ldots 6$

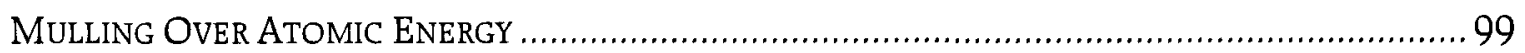

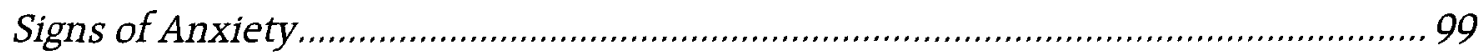

An Institutional Approach .............................................................................. 102

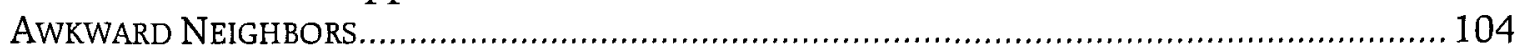

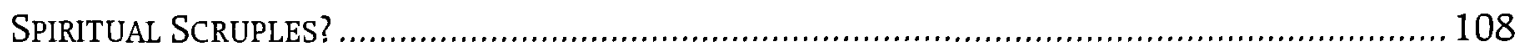

CONCLUSION: SPEAKING THE LANGUAGE OF ISLAM $\ldots \ldots \ldots \ldots \ldots \ldots \ldots, 112$

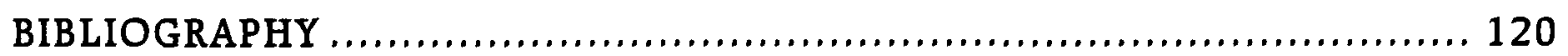

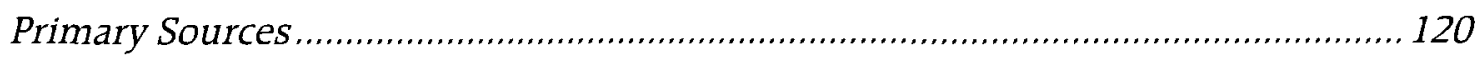

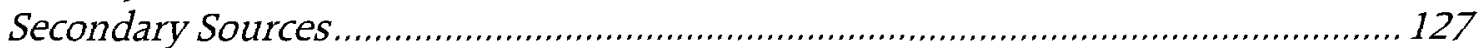

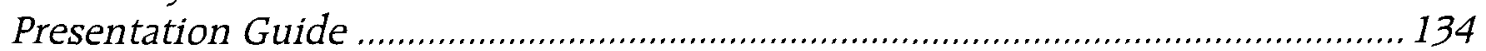




\section{Introduction}

The rapid disintegration of the Soviet Union at the turn of the 1990s left Russia, which emerged as its successor state, with far-ranging foreign policy dilemmas. Indeed, Russia's actions in the past 20 years in crisis zones as the Western Balkans and the North Caucasus have left Western scholars perplexed about the origins of the country's policy decisions. This discussion about Russian foreign policy became intertwined with the issue of the country's national and political identity, the result of which was a denunciation of perceived contradictions in policy stemming from both competitive interests and a general misunderstanding of historical lessons, and a tendency to underestimate Russia's understanding of its political surroundings and of its capacity to evoluate in it.

One such assessment comes from David Mendeloff who, in 2008, studied the case of Russia's response to the NATO bombing of Serbia in 1999. He stated that "the Russian response to the crisis reflected a profound misperception of Russia's own strategic interests, and the interests and intentions of NATO." He describes Russia's interests in purely material and economic terms. Mendeloff also notes that Russia had no formal obligation to support Yugoslavia and, despite cultural and religious closeness with Serbia, should not have intervened on their behalf because of past failures in supporting European Slavs (as in the Crimean War and the Great War). ${ }^{2}$ According to him, support was extended anyway because of a general lack of understanding of

\footnotetext{
1 David Mendeloff, “'Pernicious History' as a Cause of National Misconceptions: Russia and the 1999 Kosovo War," Cooperation and Conflict 43, no. 1 (2008): 32. Added emphasis.

2 Ibid., 32-33.
} 
historical experiences that is transmitted to the Russian public and elites by mass education and reinforced by popular culture; this, in turn, informed the Russian response in the Kosovo case. ${ }^{3}$

Ted Hopf and Andrei P. Tsygankov offer a counterpoint to Mendeloff's perspective, suggesting that multiple schools of thought exist within Russia on the matter of which course to take on foreign policy. Relating to the case of Kosovo. Tsygankov asserts that "Russia's reaction to the Western intervention was far from homogenous." ${ }^{4 "}$ This alleged irrationality of Russian foreign actions is also part of Tsygankov's argument; as evidence, he points to former Prime Minister Primakov's decision to cancel a working visit to the United States mid-flight, and he also calls contradictory two of Yeltsin's statements at the outbreak of the crisis (that Russia is both ready to defend Yugoslavia's interests and protect Russian security were they to be openly threatened, and to avoid being dragged into a war and sell arms to a third party). ${ }^{5}$ The idea of a lack of rationality in Russian foreign policy is repeated by Ted Hopf, who suggests that "[t]here is no one Russia. Instead, depending on which discursive construction of the Russian self is empowered by Russia's political system at a given time, a different Russia is acting in the world. ${ }^{6 "}$ Further disproving Mendeloff's theory of a single interpretation of history, Hopf identifies three "identities" guiding Russian

\footnotetext{
${ }^{3} \mathrm{Ibld}, 35-36$

${ }^{4}$ Andre1 P Tsygankov, "The final trumph of the Pax Americana? Western Intervention in Yugoslavia and Russia's debate on the post-Cold War order," Communist and Post-Communist Studies 34 (2001) 151

${ }^{5} \mathrm{Ibld}, 140$ These statements can easily be understood to mean that Russia will defend itself if attacked, but will not condone or engage in unprovoked foreign aggression, nor will it encourage one of its partners to do so

${ }^{6}$ Ted Hopf, "Identity, legitimacy, and the use of military force Russıa's Great Power identities and military intervention in Abkhazia," Review of International Studies 31 (2005) 225.
} 
foreign policy, including a Conservative identity which values "Soviet economic achievements, the Orthodox Church, and ethnonationalism as desirable parts of contemporary Russian identity." Moreover, according to Hopf,

Conservative identity implied a Russian alliance with anybody in the world who would balance against the United States and the West. While not ignoring the importance of economic recovery, far more emphasis was placed on Russian military power as a counterweight to the United States. Multilateral institutions were scorned, in good realist fashion. ${ }^{7}$

Hopf's description of Conservative priorities make them look if not random, at least improvised and single-minded. Mendeloff plays down the factor of improvisation for that of romanticism as a guide of Russia's foreign policy. For him, it is a

romantic image of the Serbs [that] shaped key Russian assumptions about Serbian behaviour during the crisis. From the beginning, Russians quickly and not always factually or logically - dismissed Western criticism of the Milosevic regime's conduct. [...] Claims of wrongdoing were dismissed out of hand, rationalized away, or ignored altogether. ${ }^{8}$

A clear trend comes out of these articles. Russia's foreign policy is not only disorganized (coming from as many as five different elite groupings), but even when such an elite grouping dominates, policy still cannot be expected to be uniform and well executed.

Another interesting facet of these authors' discourse is their use of the concepts of identity and civilization in their arguments. This is not the first time such concepts are used in the study of international relations. In The Clash of Civilizations, published as an article and then as a book in the mid-1990s, Samuel Huntington asserts that Russia is bound to find itself into conflict with the Islamic world, because of the

\footnotetext{
7 Ibid, 233-234. Hopf identıfies the 'Centrist' identity as domınant in 1992 Russia but, arguably, the inclinations of Putın's administration are similar to those of the 'Conservative' identity; it will therefore receive more attention in this project.

${ }^{8}$ David Mendeloff, $O p$ ctt, 44.
} 
considerable cultural gap between the two. Huntington describes Islamic states as buffer states that Russia will "in varying degrees dominate and from which it will attempt to exclude the influence of other states," and precludes the possibility of any strategic cooperation between the two because they are basically incompatible; he even predicts that the Orthodox and Islamic 'civilizations' are doomed to maintain the 'most conflictual' relations possible.' Similarly, more than a decade later, in 2007, John Anderson wrote an article about the relationship existing between the Russian Orthodox Church and the Russian state. On the matter of foreign policy, he concludes, from the study of a few Church and State documents, that in Russia, "religion is linked to nationalism: With Orthodoxy as the national religion, competitors (especially Catholics and "sects") can be depicted as threats to the religion of the nation, thus to the nation itself." Yet, despite singling out Catholics in the previous quote, Anderson spends more time explaining the security threat posed by Islam, resurrecting the old Huntingtonian paradigm of Orthodox-Islamic conflict. ${ }^{10}$ While not overtly suggesting that conflict will break out between the Orthodox civilization and others, some of their suggestions point in that direction.

This point is admittedly weaker in Tsygankov's article, since he clearly attributes a desire for a dialogue between nations and civilizations to all but the most radical of the different perspectives he identifies. For Tsygankov, this desire for a dialogue between civilizations is stronger for the Statists, roughly equivalent to Hopf's

\footnotetext{
${ }^{9}$ Samuel Huntington, The Clash of Civilizations and the Remaking of World Order (New York: Simon \& Schuster, 2003), 164, 241-245. Huntington's theory will be discussed in more detail in chapter 1.

10 John Anderson, "Putin and the Russian Orthodox Church: Asymmetric Symphonia?" Journal of International Affairs 61, no. 1 (Fall/Winter 2007): 195.
} 
Conservatives for their dedication to the principles of $19^{\text {th }}$-century realism ${ }^{11}$ For his part, Mendeloff does not make this point intentionally, but it nevertheless present in his argumentation According to his analysis Russian textbooks promote a view of history from which Russian self-interest is purged to promote the idea of the civilizational closeness of Orthodox Slavs It is for them that Russia engaged, throughout the late $19^{\text {th }}$ and early $20^{\text {th }}$ centuries, in wars against Muslim polities ${ }^{12}$ Mendeloff, by explaining Russian policy responses to NATO bombing of Kosovo in 1999 by 1dentity factors, indirectly suggests that Russian leadership is predisposed to adopt either a proOrthodox Slav or ant1-Muslım bias when dealıng with an international conflict Admittedly, Russia's policy choices and their execution probably has changed in the last ten years since the UNSC unsanctioned NATO bombing of former Yugoslavia in 1999 . the case studied in Mendeloff's and Tsygankov's articles Tsygankov suggested, in his conclusion, that "the West should develop a better understanding of non-Western cultures and their moral and political contexts ${ }^{13 "}$ This study, by building on existing literature on Russian foreign policy towards Islamic states and the international developments of that last decade, will attempt to do that

In this spirit, it is important to consider a few questions concerning Russia's foreign policy goals, orientations and first and foremost tools and instruments in Islamic polities This will follow a discussion about the role and purpose of the Russian Orthodox Church in high political circles and the bureaucracy The validity of such a trend, Russia's cooperative behavior towards Islamic states, will then be established

11 Andreı P Tsygankov, $O p \quad c t t, 138-139$

${ }^{12}$ David Mendeloff, $O p$ ctt, $41-43$

${ }^{13}$ Andrei $\mathrm{P}$ Tsygankov, $O p$ clt, 154 
through the study of relevant, contemporary issues in Russian foreign policy. In this fashion, it will be possible to find out how Russia deals with international situations where cultural and "civilizational" (to borrow Huntington's questionable terminology) differences exist. Finally, the thesis will discuss the implications of the research results, on both the political and academic levels, for Russia's relations with the West by suggesting possible avenues of further research. But, first, it will be important to determine how Russia, which has a political elite that openly and closely associates with the Russian Orthodox Church, can successfully articulate a cooperative foreign policy based on identification with Muslim states through an observer status in the Organisation of The Islamic Conference, an umbrella group of Islamic countries.

It will be argued that the case of Russia's foreign policy with Islamic states closely corresponds to multiple models of international relations theories. In this sense, it has a more systemic and planned character than some Western experts argue (this will be examined in deeper detail in chapter 1 by a brief review of relevant literature). Moreover, the proposition that Russia is responsible in its behavior towards the Islamic states, while it can certainly be understood to be part of the new "globalist" approach of the former on the international stage, ${ }^{14}$ cannot be fully explained by this hypothesis (that Russia closely identifies - on a cultural level - with its interlocutors); along a similar line of reasoning, this study will establish a new interpretation of Russian foreign policy by attempting to answer the following questions: Does Russia enjoy success in its dealings with Islamic states and, if yes, how is it achieved? Why does a seemingly influential Orthodox Church accept such engagement with Islamic states

\footnotetext{
${ }^{14}$ This view was aired by Dr. Bobo Lo during a visit to Carleton University in the fall of 2008.
} 
when, according to Huntington and other experts, religious identity should be a source of conflict? How does it inform knowledge about Russian foreign policy as a whole? These questions indicate why it is crucial to understand how, as an institution heavily influenced by the Russian Orthodox Church on many levels, the Russian state formulates a foreign policy that has a pronounced Islamic emphasis. The argument will be constructed around the following theoretical propositions:

$\mathrm{TP}_{1}$ : Cooperation between Church and state in foreign policy matters was abetted and even fostered by the Russian political elite, even President Putin himself, during his time in office.

$\mathrm{TP}_{2}$ : Socializing with Islamic states within the Organisation of The Islamic Conference has reinforced the Russian state's identification with Russian Orthodoxy.

$\mathrm{TP}_{3}$ : This perceived reinforcement of Orthodox identity within the Russian political elite has not precluded the constructive development of international relations with Islamic states.

It is understood that the previous hypotheses apply to the developments that have taken place in Russian international relations between 2000 and 2008.

This period, Putin's two presidential terms, is of significant importance to the study of Russia's international relations. It is in this period that Russia decisively recovered its position of geopolitical clout thanks to substantial oil revenues that allowed Russia to re-engage more proactively in world affairs. ${ }^{15}$ It is also during this period that Putin started making more overtures to, on the one hand, the Russian Orthodox Church, with which the Russian bureaucracy (and more specifically, the

15 Sergei Blagov, "Putin Aims for Higher Russian Profile", Power and Interest News Report (26 January 2004), www.pinr.com (accessed 22 January 2009). 
Ministry of Foreign Affairs) became increasingly close to during the course of first decade of the $21^{\text {st }}$ century. ${ }^{16}$ On the other hand a rapprochement with Muslim states as also been effected, underscored when Russia joined the Organisation of The Islamic Conference as an observer-nation in 2005. ${ }^{17}$ Moreover, during Putin's presidency Western criticism of the Russian Federation's foreign policy intensified, leading some to denounce the country for the perceived use of heavy-handed tactics in its international relations. ${ }^{18}$ All of these factors, national and international, affect the choice of research methodology to use to develop the argument.

\section{RESEARCH METHODOLOGY}

Drawing mostly upon qualitative sources, the analysis in this research project will take an empirical and deductive form. Even while theory of the field of international relations and foreign policy analysis will be used, there will be no attempt to test the validity of these theories in relation to the object of study (the theories will still be analyzed and criticized in order to determine their own internal cohesion). Instead, the emphasis will be to use this body of theory to formulate an explanation for Russia's behavior towards Islamic states. After all, reaching a better understanding of these

16 John and Carol Garrard, Russian Orthodoxy Resurgent: Faith and Power in the New Russia (Princeton: Princeton University Press, 2008), 249.

17 МИД России, Заявление Министерства иностранных дел Российской Федерации в связи с объявлением о предтавлении России статуса наблюдателя в ОИК (Москва: Министерство иностранных дел Российской Федерации, 2 February 2005), www.mid.ru (accessed 24 January 2009).

${ }^{18}$ Christopher Walker and Robert Orttung, "Putinism's Impact on Its Neighbours," Radio Free Europe / Radio Liberty (12 February 2008), www.rfe-1l.org (accessed on 15 March 2009). In this article, the authors argue that Russia's foreign policy has suffered from a lack of transparent governance (owing to the absence of democratic checks on the leadership's decisions). This authoritarian streak would have been extended to how Russia conducts its international relations. 
complex relations, and drawing policy recommendations based on this, is the main motivation behind the realization of this project.

\section{Criteria for the Selection of Case Studies}

In order to properly analyze Russian foreign policy towards Islamic states, it is necessary to draw upon data from more than one case. From these, it will be possible to establish a trend, explain phenomena present in Russian foreign policy, and draw useful lessons, rather than merely describing the policy towards the countries chosen for the case studies. The countries that are to be case studies will each be selected according to the following criteria:

- The country in question has to be a full member of the Organisation of The Islamic Conference: Otherwise, it would be impossible to reliably assess the perceptions of involved Muslim countries towards Russia's participation in the OIC, and to find out how this state of multilateral relations influences bilateral ones;

- Diplomatic representation between the chosen country and Russia has to be reciprocal and active: For the purpose of this research, active bilateral relations is taken to mean that each country's diplomatic missions pursue specific goals surpassing routine consular and trade interests, and/or high-level visits are take place with some regularity between the countries;

- The outstanding issue(s) alluded to in the previous criterion must be perceived by the involved countries to be potential sources of conflict: This is an issue where the stakes involved are of a zero-sum character 
(one's gain is the other's loss), such as control over a territory, a valuable resource, or prestige within their own constituency.

For the purpose of this study, an Islamic country is a country where the significant majority of the population adheres to (or identifies with) Islam as a religion, and where there are strong proponents and critics of Islam's role in the country's governance. The presence of prominent and respected religious leaders in the political elites would be one indication of such a debate about religion. The political elites, in Russia as in the selected countries, are understood to be the main decision-makers, that is to say the heads of state and government and cabinet ministers. The selected cases are discussed in deeper detail in the next section.

\section{Sources of Data}

Owing to the focus put on discourse analysis within poststructuralism, discourse will naturally be the main source of data in this project. The types of discourses 'observed' will vary mostly by the type of documents that are to be analyzed. Declarations by officials and politicians, the annual Address to the Federal Assembly by the President, significant press releases, radio and newspaper interviews of officials, records of meetings, and other documents pertaining to the establishment and communication of institutional policies are all amongst the types of discourses to be used as data in this project. These documents will be obtained through the electronic archives and releases of the Moscow Patriarchate, on the one hand, and select institutions of the Russian state, on the other. The Ministry of Foreign Affairs and the Kremlin (the Office of the 
President) are considered to be the most suitable proxies for the Russian state in this project. ${ }^{19}$ When appropriate, similar documents from the case study states will be used.

It is to be expected that most documents obtained from Russian state institutions, as well as from the Moscow Patriarchate, will be in Russian. In this project, these sources are referenced in the original Russian (and Cyrillic) in both the footnotes and in the bibliography. This is done so that reference to those documents by Russianspeakers, who are considered the most likely to consult the original texts, might not be impeded by translated or transliterated titles (which can make it complicated to find them with search engines). However, direct quotes from Russian sources will always appear in English in the main body of the text, with the original Russian in the footnote (again, for ease of reference to a greater number of readers). Finally, readers who understand neither Russian nor Cyrillic should be aware that the official documents reference very often have very descriptive titles, generally including the title and name of the official, the type of comment that was made and the issue to which it relates, along with the location of the official at the time, and the date. These are generally referred to in English within the text.

\footnotetext{
${ }^{19}$ Marie-Christine Kessler, «La politique étrangère comme politique publique,» dans Frédéric Charillon, Politique étrangère: Nouveaux regards (Paris: Presses de Sciences Po, 2002), 169.
} 
In this research project, the argument will be presented in five chapters. The theoretical aspects will be discussed in the interlude and in the conclusion. Here is an overview of which ideas will be discussed in each chapter.

\section{Chapter 1: Bringing Agency Back In}

Since the texts presented above stress the structural dimensions of religion in Russian foreign policy (particularly Samuel Huntington's Clash of Civilizations), agency-based factors need to be reintegrated into the research project. Even though this is partially done by the adoption of a poststructuralist ontological perspective, which stresses the importance of discursive construction - and therefore agency, one also needs to have a framework to understand the effects of the policy constructed in this way. The effects, or results, of foreign policy, are considered to be international relations. For this reason, a theoretical framework for the explanation of international (as well as domestic-social) phenomena stressing agency-based factors is established in Chapter One. This set of assumptions is composed of the constructivist theory with regards to international relations, and a few complementing theories of the sociology of religion for internal factors. Theoretical texts conceptualizing two-level games (in other words, the link between the Church-State domestic dichotomy on the one hand, and the state in its international iteration on the other) are also included in the analytical framework. 


\section{Chapter 2: Dreams of Symphonia}

Chapter Two establishes Russia as an 'Orthodox state' according to much the same criteria outlined for Muslim states in the previous part, a characterization on which the very basis of this project depends. This will be done by showing evidence of the Russian Orthodox Church's desire to exercise an influence on Russian society and politics, the responsiveness of the state to such overtures, and the people's acknowledgement that such an exchange between Church and State is taking place.

\section{Chapter 3: Showcasing a Minority}

Chapter Three will slowly shift the focus away from Church-State relations to seeing how the Russian state perceives and represents its relationship with its own Muslim minority, and the Organisation for The Islamic Conference (OIC). The OIC is seen as an institutional proxy for the 'Islamic world' (a diffuse concept, as will be discussed in Chapter One) that can serve as a specific interlocutor for the Russian state in its relations with Islamic states. This will lead into the discussion of more specifically international matters in the case studies of chapters Four and Five.

\section{Interlude: Manus Dei}

The interlude will contain the theoretical recap of the observations and analysis in Chapters Two and Three. In other words, it will review the key points of the argument with links to the theoretical framework of the first chapter. This is done to lighten the tone of both parts, and to render the text more accessible to readers less familiar or otherwise less interested in the intricacies of theory and who would rather concentrate on the substance. 


\section{Chapter 4: Flirtations with the Holy Kingdom}

Saudi Arabia is the foremost Islamic country in the world, maybe on the political level, but surely on the liturgical level: this is where Islam's holiest cities, Mecca and Medina, are located, where every Muslim, according to the fifth pillar of Islam, must complete a pilgrimage at least once in his life. To put it succinctly, Saudi Arabia is custodian of the territory where Islam was first revealed to Mohammed.

Now, Saudi-Russian relations have been of an irregular character since Saudi Arabia's formation in the early twentieth century. It seems that this trend will be reversed, as the past few years have seen a lot of high-level contacts and visits taking place between officials of the two countries. Both countries have an interest to improve bilateral relations, since they are competitors as fossil fuel producers and suppliers. ${ }^{20}$

During the last decade, many new agreements have been reached between the Saudi Kingdom and the Russian Federation, leading to significant increases in trade, to direct and regular consultations between both countries' deputy ministers of Foreign Affairs, and to the establishment of foundations for further cooperation in, amongst others, the sector of fossil fuel technology. ${ }^{21}$

\footnotetext{
${ }^{20}$ МИД России, Российско-саудовские отночения (справочная информачия) (Москва: Министерство иностранных дел Российской Федерации, 26 May 2008), www.mid.ru (accessed 10 March 2009).

${ }^{21}$ Ibid.
} 
Moreover. Saudi Arabia is the birthplace of Wahhabism, an extremist and politically active branch of Islam. This is of special importance for Russian-Saudi relations, since there have been persistent allegations of Wahhabite involvement in the war and continuing unrest in the Federated Autonomous Republic of Chechnya in Russia's south. ${ }^{22}$ While relations between the Saudi regime and the Wahhabi sect are too complex to fully examine within the confines of this project, they should nevertheless be introduced in this chapter, since they play an important role in shaping the international relations of the Saudi kingdom. This proved to be the case with Russia during the Putin presidencies, since Russia's National Security Concept of 2000, as John Anderson points out, mentions the goal of "counteracting the negative influences of foreign religious organizations and missionaries," a statement that does not lack significance when applied to the context of Russian-Saudi relations. ${ }^{23}$

Because of these factors, Saudi Arabia is understood to be a major country within not only the Islamic world, but also within the context of Russian foreign policy and international relations, justifying its choice as a case study. Also, on a more theoretical basis. Saudi Arabia is a country that has had, historically, relatively little contact with either Imperial Russia or the Soviet Union. In a way, this essay takes up Huntington's implicit challenge of cross-civilizational international relations analysis (from the point of view, always, of Russian foreign policy), even if the concept of civilizations, and of Islam as one, is itself challenged in Chapter One. With its disconnection from Russian

22 Dario Cristiana, "Russia's New Initiatives in the Persian Gulf", Power and Interest News Report (1 March 2007), www.pinr.com (accessed 15 March 2009).

${ }^{23}$ John Anderson, Op. cit., 194. 
history and, until recently from Russia's diplomatic contacts, Saudi Arabia provides a good case of 'cross-civilizational relations.'

\section{Chapter 5: The Conundrum of the Islamic Republic}

Russia has had many outstanding foreign policy issues with Iran, as well as a lot of programs and opportunities for cooperation with the Islamic Republic of Iran during Vladimir Putin's presidency. These include, but are not limited to:

- The construction of the nuclear reactor at Bushehr (which raises the question of Russia's response to the allegations as to the exact nature of Iran's nuclear program, a program that has faced vocal opposition from the Western world);

- Disagreement about how to divide the Caspian Sea; ${ }^{24}$

- Iran's interest to join the Shanghai Cooperation Organization, first as an observer-nation, then as a full member (hinting at Iran's geopolitical interests in Central Asia) $;{ }^{25}$

- The country is a significant market for Russian products. ${ }^{26}$

As such, it is obvious that Russia's geopolitical stakes are high when dealing with Iran, and therefore their relations have the potential to degenerate into conflict.

As the title of this chapter suggests. Iran presents Russia with a dilemma, because of the intersection of variables other than the significance of the country for

\footnotetext{
24 John W. Parker, Persian Dreams: Moscow and Tehran Since the Fall of the Shah (Washington, D.C.: Potomac Books, Inc., 2008), 147.

${ }^{25}$ Marcel de Haas, "S.C.O. Summit Demonstrates Its Growing Cohesion", Power and Interest News Report (14 August 2007), www pinr.com (accessed 22 January 2009).

26 МИД России, О торгово-экономическом сотрудничестве с Исламской Республикой Иран (справочная информачия) (Москва: Министерство иностранных дел Российской Федерации, 2 March 2009), www.mid.ru (accessed 10 March 2009).
} 
Russian national interest. A member of the OIC, Iran has a theocratic regime that faces pressure at home to modernize and abandon, or at least tone down, its Islamic rhetoric and social policies. ${ }^{27}$ As such. Russia has an incentive to strike a balance in the use of cultural elements in the language it adopts towards Iran in order to placate the current regime and plan for its possible replacement by a more secular variant. Fully analyzing the internal Iranian political arena is not possible due to the limit of the scope, but its implications for the study of foreign policy towards Iran will be pointed out.

In the same spirit as Saudi Arabia, Iran is seen as a country presenting Russia with both significant challenges and opportunities and is also widely recognized as a major country within the Organisation of The Islamic Conference. This is why it was chosen as the second case study for this project. It is arguable that Iran presents a case similar to Saudi Arabia, if not from the perspective of long-term history, in which Russia and Iran have had extensive contacts through Russia's imperial ambitions and instances of skirmishes throughout Peter the Great's reign and also in the early $20^{\text {th }}$ century. ${ }^{28}$ Political upheavals in Iranian politics in the last quarter of the $20^{\text {th }}$ century led to a significant, if not complete, break in historico-social continuity (this will be studied in further, though not exhaustive, detail in Chapter Five). At the same time, Iran presents challenges for Russia; there is a debate within Russia about whether or not, and to which extent, it should engage with Iran. This debate has bases in ideational and

${ }^{27}$ Nikki R. Keddie, Modern Iran: Roots and Results of Revolution (New Haven and London: Yale University Press, 2006), 263.

${ }^{28}$ С.Ф. Платонов, Лекиии по русской истории (Санкт-Петербург: Золотой век, 2004), 419-420; Nikki R. Keddie, Modern Iran: Roots and Results of Revolution (New Haven \& London: Yale University Press, 2006), 57, 62-63;John W. Parker, Op. cit., 1-3. 
materialist contexts, ${ }^{29}$ making it interesting to delve deeper into this conundrum of Russia's foreign policy with an approach combining these two factors into its theoretical perspectives (the theory is further developed in Chapter One).

\section{Conclusion: Speaking the Language of Islam}

The conclusion will, in the same fashion and spirit as the interlude, effect the last theoretical recap of this essay, covering the case studies. It will also draw general conclusions about the essay's findings.

\section{ECHOES OF BYZANTIUM}

Ties between the Church and the State have existed for a very long time in Russia. This close relationship between Churches of the Orthodox denomination can be traced all the way back to Byzantium, where this cooperation was "understood and written of" as "symphonia." "They worked together in harmony towards common goals," writes Thomas Bremer. ${ }^{30}$ The history of Russia's statehood is closely associated with that of the Orthodox Church, and became even more enmeshed during Peter the Great's reign when the Church became a department of state, becoming one of its "pillars." ${ }^{31}$

This movement of convergence continued throughout history to the point that, according to research done by White and McAllister, belonging to the Orthodox Church had become all but coterminous with belonging to the state by the turn of the previous

\footnotetext{
29 Anastasia Mitrofanova, The Politicization of Russian Orthodoxy: Actors and Ideas (Stuttgart : ibidemVerlag, 2005), 54; John W. Parker, Op. cit., 157.

30 Thomas Bremer, Kreuz und Kreml: Kleine Geschichte der orthodoxen Kirche in Russland (Freiburg im Bresgau: Verlag Herder, 2007), 111-112. Free translation.

${ }^{31}$ John Anderson, Op. cit., 185.
} 
century, leading to an original relationship between the faithful and the congregation. Towards the end of the Communist period, sense of belonging to the Church was centered around communal values rather than on adherence to (or even knowledge of) a liturgical code. ${ }^{32}$ Repression of Church institutions varied depending on who was Party secretary at any point in time, but was mostly left to its own devices so long as it did not challenge the orthodoxy of Communist dogma directly or openly; otherwise, it was dismissed by the Soviet regime as a 'superstition' that would eventually disappear. Also, it was discovered that the Orthodox Church shared a few values and principles with Marxism-Leninism (commitment to family life, a strong and unified Russia) that allowed it to continue acting as an element of continuity in Russian society, a fact that was recognized by the Soviet leadership..$^{33}$

Just as the Church had managed to reinvent itself and remain socially relevant when the workers' councils replaced the imperial court, so was it able to adapt to a new environment when the Hammer-and-Sickle left its place, which was to be occupied once more by Peter the Great's tricolor. Thomas Bremer contends that it is still uncertain how the Church-State relationship will play out in postcommunist times. He points out that while the Church has not yet been able to renew its niche, its historical resilience as an element of continuity should incite the state to leave to it some "room for manoeuvre" on social issues. ${ }^{34}$

\footnotetext{
${ }^{32}$ Stephen White and Ian McAllister, "Orthodoxy and Political Behavior in Postcommunist Russia," Review of Religious Research 41, no. 3 (2000): 361, 363 At the very least, White and McAllister's conclusions, reached by extensive research based on surveys and interviews, shows that the correlation between belonging to the Church and having knowledge of the Orthodox liturgy was weak at best.

33 Ibld, 361 .

34 Thomas Bremer, Op ctt, 139-141.
} 
Already, during the transitory period under President Yeltsin's terms, the Church has shown it had the ability and confidence to define itself not only in relation to social issues, but also political ones. One only has to look at the role the Church and the Patriach himself, Aleksy II, played during the coup attempt by the State Emergency Committee in August 1991, and again when it overtly supported President Yeltsin, once more, this time in his re-election bid of $1996 .{ }^{35}$ Moreover, John Anderson identifies four areas on which the Church has found some measure of common ground with the new government: the problematic of the liberalization and Westernization of the state; the notion of "managed pluralism"; security matters; and religious education. ${ }^{36}$ Interest in security matters implies an international dimension in how the Church articulates its social position.

This interest, according to both Anderson and especially Garrard, are intimately tied to the Moscow Patriarchate's concern with the proselytizing 'threat' it sees in the Roman Catholic (Latin) Church; these concerns overshadow the possible challenge posed by Islam. As John Garrard puts it, the Church "fears the infidel more than the heretic. ${ }^{37 . " ~ I n ~ o t h e r ~ w o r d s, ~ t h e ~ P a t r i a r c h a t e ' s ~ p r e o c c u p a t i o n ~ w i t h ~ C a t h o l i c i s m ~ i s ~ m o s t l y ~}$ liturgical. Roman Catholicism, however, does not have the same presence in Russia as Islam, another major proselytizing religion, nor does it even have the same presence within the states from which it originates, since the Western world is largely secular,

\footnotetext{
35 John and Carol Garrard, Op. cit., 20; John Anderson, Op. cit., 187.

${ }^{36} \mathrm{Ibid} ., 186$.

37 John and Carol Garrard, Op. cit., 141.
} 
with the separation of spiritual and temporal affairs usually being quite strict (naturally, there are some notable exceptions to this order of things).

In more recent years, the Church's role, or at least interest, in social and political affairs seems to have only expanded. Right after his presidential inauguration. Putin made a symbolic visit to the Patriarch Aleksy II, who celebrated a brief service to highlight the event (Anderson, recounting this, mentions Putin's seeming lack of knowledge of Orthodox liturgy, which would correspond to White and McAllister's findings about adherence to Orthodox principles in Russian society). ${ }^{38}$ At the same time, new developments in Russia were happening, and would have to be dealt with, such as the conflict in Chechnya, which had come back centerstage after the Moscow apartment bombings of 1999, while Putin was prime minister, and who had already initiated a response to the crisis. ${ }^{39}$ However, this conflict could not be resolved only through federal intervention in the autonomous republic, since rebellious elements there had outside patrons. Also, having re-acquired a certain amount of confidence and material means, Russia intended to shape the international system towards a more developed multipolar order (both of these previous ideas will be further explored in the case studies). Seeing that Russia then was not a fully developed democracy, Russian state institutions were the most apt to come up with solutions to these foreign policy dilemmas. ${ }^{40}$ These institutions still had to take into consideration the interests of a

\footnotetext{
${ }^{38}$ John Anderson, $O p$ clt, 185.

${ }^{39}$ Lilia Shevtsova, Putın's Russia (Washington, D.C.: Carnegie Endowment for International Peace, 2005), 134-136

40 Ibid., 192; Vladimır Gel'man, "Party Polıtıcs in Russia: From Competition to Hierarchy," Europe-Asia Studies 60, no 6 (Aug 2008), 913-930, Henry E. Hale, "Yabloko and the Challenge of Bulding a Liberal Party in Russia," Europe-Asia Studies 56, no.7 (Nov 2004): 993-1020; Mar1e-Elisabeth Baudoin, "Is the
} 
powerful Moscow Patriarchate, which had been an institutional alternative to the state in earlier phases of history and which would want to exercise its influence on social policies, ${ }^{41}$ on the one hand, and those of an increasingly assertive Muslim minority, on the other. Because the Kingdom of Saudi Arabia and the Islamic Republic of Iran would be unavoidable interlocutors in the coming years, the Russian state had to devise a way to harmonize and address these contrasting influences. Some have predicted that international conflict would ensue in such a scenario, but this does not seem to be the case here. So, it is pertinent to more fully explore those questions from the perspective of Russian foreign policy to better understand how the Russian state responded to those challenges. A theoretical framework for doing so is discussed in the next chapter.

Constitutional Court the Last Bastion in Russia Against the Threat of Authoritarianism?" Europe-Asia Studies 61, no. 5 (Jul 2009): 779. These scholars, amongst others, have argued this idea according to many problematics that have articulated the problem in much stricter language than 'not a fully functioning democracy' Exploring these arguments is not the object of this essay

${ }^{41}$ Stephen White and Ian McAllister, $O p$ clt , 361, Thomas Bremer, Op cit , 139. 


\section{Chapter 1: Bringing Agency Back In}

In order to produce an enlightened analysis of Russia's foreign policy, it is necessary to examine the dominant paradigms in the field of international relations theory and foreign policy analysis. Doing so will make it easier to situate Russia's foreign policy within the theoretical field of international relations, and will provide arguments for a follow-up analysis of the interplay between the influence of the Moscow Patriarchate on Russian foreign policy and the implementation of that same policy in the Muslim world.

Considering the sheer amount of theories in the fields of international relations theory and foreign policy analysis, it is impossible to fully analyze every one of their existing variations. The analyzed theories have been chosen on the basis of the explanations they can provide on Samuel P. Huntington's The Clash of Civilizations, the criticism of whose assumptions this research project is partially based on. Therefore, a critical discussion of Huntington's work provides the project's theoretical foundation.

The analysis of Robert D. Putnam's and Peter Gourevitch's competing theories of two-level games will constitute the first part of the literature review because, in this case, the Russian state itself faces a two-level dilemma: how to reconcile the Orthodox Church's influence on the domestic level with the perceived necessity or at least desirability of pursuing deeper relations with Muslim states abroad. Putnam's and Gourevitch's theories also complement the ideas of constructivist and liberal theories presented below. 
Second, a comparative analysis of the paradigms of neorealism and constructivism will be attempted. Like Samuel P. Huntington's theory, both are statecentric theories of international relations. Since it is the first theory of neorealism. Waltz's Theory of International Relations was chosen to represent the realist field (through various articles), while Alexander Wendt's Social Theory of International Politics will form the cornerstone of the study of constructivism (both from the core book and supporting articles). Owing to its relevance to the argument, a short discussion about the liberal theory of international relations closes this section.

A study of current theories in the field of the sociology of religion will complete the theoretical exploration of this chapter. Indeed, no serious study of the political influence of the Russian Orthodox Church can be complete without a thorough understanding of the dynamics governing the evolution of such organizations in society. When light will have been shed on the societal factors leading to the position of religious interests relative to the governing elites and society at large. these will be inserted into the findings from the theories of international relations in order to build a strong framework from which to analyze the data that will be scrutinized in this research project.

The current theoretical analysis will be engaged by taking a closer look at Samuel P. Huntington's main contribution to the field of political science, The Clash of Civilizations. 
Published shortly after the end of the Cold War, Samuel P. Huntington's cornerstone work of international relations created a controversy by predicting that conflicts in the new world order would be identity-based rather than ideology-based. ${ }^{42}$ While this basic idea might bear some truth, according to the trends Huntington identifies, his theory still lacks theoretical clearness and cohesion. For example. Huntington predicted that "[...] Russia is creating a bloc with an Orthodox heartland under its leadership and a surrounding buffer of relatively weak Islamic states which it will in varying degrees dominate and from which it will attempt to exclude the influence of other powers", ${ }^{43}$ while seemingly contradicting himself by later suggesting, on a graphic, that Russia and the Islamic world are headed towards "more conflictual" relations (while relations with the West are considered relatively less conflictual). ${ }^{44}$ As will be argued in the following chapters of this study, these predictions have simply not withstood the test of time.

Three aspects have been chosen for deeper criticism, since they are closely linked to the current research project. These aspects are the following: the reasons identified for the outbreak of inter-group conflict; the process and criteria by which those groups and civilizations are formed; and, the operationalization and execution of group preferences by group leaders. The case against Huntington's theory will be made with help from scholarship mainly by Georges Corm, Jacques Rancière, and Jeff Haynes,

\footnotetext{
${ }^{42}$ Samuel P. Huntington, Op. cit., 32.

${ }^{43}$ Ibid., 164.

${ }^{4}$ Ibid., 245.
} 
who have published work in the field of the interaction of religion with different facets of international politics.

The flawed logic of "fault line conflicts"

According to Huntington, conflicts between identity groups are precipitated by the end of Western hegemony over the world and that, in its wake, a multipolar, multicivilizational world resulted from the end of that hegemony. ${ }^{45}$ In itself, this supposition is insufficient to explain why the creation of a world order would be accompanied by conflict. Indeed, Huntington does not fully explain why he expects such conflicts to emerge, instead preferring to offer characteristics of such conflicts, derived from past examples of such ${ }^{46}$ He even suggests that conflicts do not have a strong identity dimension when they start, but rather develop a "hate dynamic" as they degenerate, further undermining his argument. ${ }^{47}$ When he offers actual justifications for inter-group conflict, such as the heritage of history, demographic pressures, and victim status (the latter unexplainably being solely attributed to the "contemporary Muslim propensity for violence"), he fails to make a convincing argument for why they cause conflict (and for why these factors should be specific to conflicts between groups of different religion or language or ethnicity). Instead, he concentrates on the enumeration of cases where these criteria did cause conflict. ${ }^{48}$ This logic of inter-group conflict is supported by other scholars in the field of political science and religion. As it will be possible to see, their points of view are complementary and, while having their

\footnotetext{
${ }^{45}$ Ibid., 53.

46 Ibid., 252.

${ }^{47} \mathrm{Ibid} ., 266$.

${ }^{48}$ Ibid., $259 \& 263$.
} 
own flaws, provide better explanations than Huntington for the prevalance of intergroup conflict. Also, Corm and Haynes introduce elements that will be studied more deeply in the second part of this chapter. Indeed. Corm states the following:

L'identité fonctionne en référence à un pôle négatif: la vision de l'autre, différent sinon ennemi. C'est pourquoi tout système de valeurs structurant l'identité est en même temps une composante essentielle du système de pouvoir qui organise l'ordre à l'intérieur d'une société et décide de la guerre ou de la paix avec la société voisine différente. ${ }^{49}$

By this statement, Corm adds the domestic dimension in the discourse about intergroup conflict on the international stage, a discourse that was missing from Huntington's analysis, even where the latter admits the possibility of an identity conflict on the intra-state level. Haynes supports Corm's idea of the domestic nature of identity politics by the following: "Group religiosity, like politics, is a matter of collective solidarities and, frequently, of inter-group tension and conflict, focusing either on shared or disagreed images of the sacred, or on cultural and class, in short. political, issues. ${ }^{50}$ In short, Corm and Haynes are arguing that, while identity plays a role in fomenting conflict within and between states, this conflict will emerge not because of the inherent differences, but by the multiple agencies' incapacity to compromise on a particular issue. This weakens Huntington's direct causality between identity and presence (or absence) of conflict.

Corm and Haynes, as well as Rancière, provide further explanations for the intrusion of identity (in its numerous forms, but mostly in that of religion) into politics. another aspect that is also missing from Huntington's analysis. Corm attributes the

\footnotetext{
${ }^{49}$ Georges Corm, La question religieuse au XXIe siècle: Géopolitique et crise de la postmodernité (Paris: La Découverte, 2006), 46. Added emphasis.

50 Jeff Haynes, Religion in Global Politics (London and New York: Longman, 1998), 5.
} 
rising power of religious organizations (themselves bearers of identity) on political organizations to their concomitant loss of legitimacy, for different reasons, towards the people. Their mutual involvement with each other, according to Corm, is motivated by their shared desire to stymie and reverse this trend ${ }^{51}$ Haynes also states that "leading Churches are articulating viewpoints on political and social issues more readily and openly than in the past." ${ }^{52}$ These statements by Corm and Haynes go a longer way than Huntington to justify the preeminence of identity politics within the state, even if they cannot account for conflicts between groups that do not share a common identity. Rancière offers such an explanation, partly supported by the same argument that politics and identity are intimately intermeshed with each other. ${ }^{53}$ But, he also states that this produces a "logique consensuelle [qui] s'attache à détruire les sujets supplémentaires, les altérités construites, polémiques, du dissensus politique." ${ }^{54}$ This suggests that the internal politics of a state will evolve in a way that will get rid of "minority opinions", after which the state will be ideologically, or ideally (in the sense of ideas), homogeneous. It is uncertain, however, how such a theory could be applied to the international stage, since it is difficult, if impossible to identify a "majority" or "minority" opinion, unless this concept is operationalized in relation to the balance of power between states or coalitions of states.

\footnotetext{
${ }^{51}$ Georges Corm, Op cit , 135-136.

52 Jeff Haynes, $O p$ cit, 12

53 Jacques Rancière, «Citoyenneté, culture et polıtıque,» in Mondialısatıon, citoyenneté et multıculturalisme ed Mikhael Elbaz and Denıse Helly (Québec Les Presses de l'Unıversité Laval): 66

${ }^{54}$ Ibld , 67
} 
But, from the current findings, it is possible to conclude that Huntington is unable to fully explain how conflicts between groups can break out on the basis of identity, to the apparent exclusion of political factors. Moreover. Huntington's definition of these groups, or civilizations, is likewise unsatisfying, for the reasons that will now be exposed.

\section{A clash of what?}

Another problematic dimension of Huntington's analysis is his concept of civilizations. The numerous and diverse criteria he uses to define civilizations not only contradicts itself on a few important counts (specifically on the question of a civilization's durability), but he even states that a civilization's boundaries are "seldom sharp," 55 diminishing the concept's use in a theoretical perspective.

The scope of this chapter is not sufficient to explore every flaw of Huntington's general methodology for delimiting civilizations in a larger sense, it is useful to look at the definitions he gives for the two civilizations that are central to the current analysis, the Orthodox and the Islamic. The definition of the former is problematic, since it specifically refers to Russia and, by doing so, lumps together countries that do not share the same historical experience ${ }^{56}$ (such as Greece, Serbia, Bulgarıa, and Romania ${ }^{57}$ ). Even

\footnotetext{
55 Samuel Huntington, $O p$ cit , 43-44

${ }^{56} \mathrm{Ibld}, 45-46$ This counterpoint might not seem convincing, since Huntıngton points to religious identity as the source of belonging to a civilization However, there exists multiple denominations of the Orthodox Church based on national belonging (for example, Greek Orthodox, Russian Orthodox - which was even internally split untıl recently, Latvian Orthodox, etc ). Owing to this, the Orthodox world cannot be said to be truly monolithic, even from a strictly religious perspective

57 Ibld, 27.
} 
more questionable is Huntington's case for an Islamic civilization that is justified on the basis that "all major scholars recognize the existence of a distinct Islamic civilization," 58 a statement that is beautifully contradicted by Corm:

Malheureusement, on ne peut plus dire qu'il est une civilisation (pas plus que ne l'est d'ailleurs le christianisme), compte tenu du déclin historique qui a affecté il y a plusieurs siècles déjà les grands centres de ce qui fut la civilisation islamique. Il n'est pas davantage une culture, car différentes langues sont pratiquées dans les pays où domine la religion musulmane. L'islam n'est donc qu'une religion $[\ldots]^{59}$

Thus, it is possible to assert that Huntington should have followed his own prescription and defined his "civilizations" in primordially (or even purely) religious terms, even if his idea for doing so was unabashedly Western. Moreover, Huntington himself denies the cohesion of civilizational blocs by affirming that they do not engage in the same acitivies as states, that "they do not wage war." Therefore, it is difficult to theorize their clash without making it an unavoidable eventuality. Indeed, civilizations that are formed by a single or dominant states (Sinic, Japanese, Orthodox), or amorphous civilizations that do not have clear leading states (Latin American. Islamic), ${ }^{60}$ are bound to get into conflict with each other, owing to the already observed mechanisms of the international system. ${ }^{61}$

\section{Taking It Down a Notch}

As has been mentioned earlier, Huntington's theory does not fully take into account the importance of domestic politics in the formation of identity itself, and the foreign policy

\footnotetext{
${ }^{58}$ Ibid., 45.

${ }^{59}$ Georges Corm, Op. cit., 186

${ }^{60}$ Samuel Huntington, Op. cit., 40-45.

${ }^{61}$ Ole R. Holsti, "Models of International Relations and Foreign Policy," Diplomatic History 13, no. 1 (1959): 15 .
} 
choices that stem from such an exercise. Both Robert D. Putnam and Peter Gourevitch enounce theories that seek to assess the influence of internal factors in the formulation of foreign policy. First and foremost, Robert Putnam denies the use of the bureaucratic theory (which stipulates that policy formulation results from a power-play between state organs that have a singular view of how to resolve an issue depending on their respective function). ${ }^{62}$ This repudiation is based on the fact that bureaucratic theory cannot fully account for exactly how bureaucratic politics affect foreign policy, focusing instead on proving that it does. This dimension is important to properly evaluate, since it might support Corm's and Haynes' theories about the state and the church giving each other mutual support in order to achieve their respective agendas. Putnam summed it up in the following way:

At the national level, domestic groups pursue their interests by pressuring the government to adopt favorable policies, and politicians seek power by constructing coalitions among those groups. At the international level, national governments seek to maximize their own ability to satisfy domestic pressures, while minimizing the adverse consequences of foreign developments. [...] Nevertheless, there are powerful incentives for consistency between the two games. Players (and kibitzers) will tolerate some differences in rhetoric between the two games, but in the end either energy prices rise or they don't. ${ }^{63}$

By stating this theory, and one of its main foundations, one of the main points of the current research project has been raised: why would an institution that obviously has the ear of the state and its decision-makers tolerate that the latter pursue a foreign policy that could be understood as being inimical to its interests? After all, according to Putnam's theory, such a scenario is unlikely, since an interest group or other corporate group within society that carries a lot of influence with the government will inevitably

\footnotetext{
${ }^{62}$ Robert D. Putnam, "Diplomacy and Domestic Politics: The Logic of Two-Level Games," International Organization 42, no 3 (1978) 431.

${ }^{63}$ Ibld, 434.
} 
seek to have its interests promoted by that government on the international stage. In other words, why would the Moscow Patriarchate support the expansion of relations with the Muslim world if it did not perceive interests in doing so? Again, this poses the question of what these interests are.

Another of Putnam's statements, "that the unitary-actor assumption is often radically misleading," ${ }^{64}$ drives the point home: Huntington's theory is flawed because it does not take into account for the possibility of divergence in internal interests in foreign policy formulation. Even in states that are reputed to be autocratic or undemocratic, elites often have to cater to the preferences of multiples states agencies (or actors), be they different branches of the army, security services, a strong Church, or even provincial or minority interests in the case of federal and/or multicultural states. Putnam also suggests a methodology for the analysis of two-level games, pertaining both to the types of variables that should be used and the process to be followed. On the question of process. Putnam advances that the study of the international level (Level I) should come first, and then be followed by an analysis of the internal compromise phase (Level II). This approach, as Putnam himself acknowledges, is not "descriptively accurate, ${ }^{165}$ and seems arbitrary, since the sequence is never fully explained. For this reason, in this research, Level II will be analyzed first, since it is the impetus for a state's foreign policy, it defines what is acceptable: "[...] the need for Level II ratification is certain to affect the Level I bargaining. In fact, expectations of rejection at Level II

\footnotetext{
${ }^{64}$ Ibid., 433.

${ }^{65}$ Ibid., 436.
} 
may abort negotiations at Level I without any formal action at Level II." ${ }^{66}$ This is an approach that is more appropriate as the object of this research is the study of a longterm phenomenon (facets of Russia's foreign policy over the years 2000-2008), and not the analysis of a specific instance of international bargaining.

Even when Putnam's understanding of the effects of internal factors on the formulation of foreign policy stresses a variety of interests at the national level, his case is not delivered with the same language as Gourevitch's assessment of the same phenomenon, although the two authors are directly in agreement with each other on a few points. Gourevitch uses vocabulary similar to that of constructivist literature (which will be analyzed in the next part of this section).

Indeed, Gourevitch makes a strong case for the importance of going beyond structure, and look at the internal agencies guiding the actions of a state on the international stage at multiple points in his analysis ${ }^{67}$ This, again, is a reminder of the importance of using an international relations theory that takes this kind of factors (the influence of - sometimes conflicting - internal agency in foreign policy formulation) into account when seeking to come up with answers, with a rational explanation for a state's behavior on the international stage, something that is cruelly missing from Huntington's analysis. Moreover, at the center of Gourevitch's argument is the insistence that international elements influence domestic ones: "First, in using domestic structure as a variable in explaining foreign policy, we must explore the extent ${ }^{66}$ Ibid.

67 Peter Gourevitch, "The Second Image Reversed: The International Sources of Domestic Politics," International Organization 32, no. 4 (1978): 883, 905. 
to which that structure itself derives from the exigencies of the international system.. ${ }^{68}$ Even though Gourevitch links his theory more closely with the liberal stream rather than the constructivist one, ${ }^{69}$ it is likely that it his theory predates the establishment of the constructivist paradigm.

So, in this sense, the work of both Putnam and Gourevitch make strong references to international relations theories that either existed at the time the articles were written, or were developed later. As such, it is important to look more closely at them, and see how Huntington, and the works of Putnam and Gourevitch, fit into them.

\section{Domesticating Foreign Policy}

Since both the neorealist and constructivist theories of international relations are generally well understood, their main points will only be summed up here. Neorealism. contends that the structure (or lack thereof - i.e. anarchy) informs state behavior in a perpetual search for security; it does not lend an identity to the state since it will not influence its acts on the international stage. In constructivism, however, societal actors in the state will shape the latter's identity which, in turn, will be shaped by its interactions with other states (that are subject to similar processes of identity formation): the international system's structure therefore evolves along with the identities of the states and the agencies within. Those two paradigms were chosen since they are the ones, as shall be exposed, that are the most directly linked with how Russian foreign policy both is and is not informed by matters of cultural and religious

\footnotetext{
${ }^{68}$ Ibid., 882.

${ }^{69}$ Ibid., 908.
} 
identity on a level suggested by Huntington. The neorealist theory will be first one considered, since it is the one most closely linked to Huntington's theory.

Neorealism has two shortcomings that prevents it from being useful in the current study: it explains a state's behavior through a structural analysis of the international system, meaning it ignores internal factors (other than material ones) and makes the assumption that, since the international system is in a permanent state of anarchy, the interests of a state (and its behavior in trying to secure them) are thus also unchanging. ${ }^{70}$ While the latter assumption is not directly rebutted by Huntington, it is worth noting that he considers it highly unlikely that a state might be able to change its behavior, owing to the difficulty of moving from one civilizational bloc to another. ${ }^{11}$ More specifically, and in support of the neorealist theory, Huntington sets two of the following four assumptions as fundaments of his theory: "Nation states are and will remain the most important actors in world affairs [...]; The world is indeed anarchical, rife with tribal and nationality conflicts [...]", even though he acknowledges the important of cultural factors in determining these conflicts. ${ }^{72}$ However, this is where Huntington breaks with constructivist theory. While he might take into account a state's identity (culture) as a factor of its foreign policy, he dismisses the likelihood of the evolution of such an identity by anchoring it in "durable" civilizations that are mostly defined by religions, themselves a long-term phenomenon. Resulting from this, Huntington fails to fully account for multicultural states except for stating that they are

\footnotetext{
${ }^{70}$ Dario Battistella, «L'intérêt national. Une notion, trois discours,» in Politique étrangère: Nouveaux regards ed. François Châtillon (Paris: Presses de Sciences Po, 2005), 141-147.

${ }^{71}$ Samuel Huntington, Op. cit., 139-140.

${ }^{72}$ Ibid., 36 .
} 
"torn countries," and cannot fully justify their inclusion in one or another civilization, except by his own personal bias. ${ }^{73}$ For his part, Wendt stresses the importance of structure, as found in Huntington, in determining state behavior, as much as he points out that this structure is heavily influenced by state actors: "The distribution of capabilities only has the effects on international politics that it does because of the desiring and believing state agents who give it meaning. ${ }^{74 "}$ In this case, of course, the "capabilities" that are referred to, applied to Huntington's theory, is culture; after all, Huntington never makes any mention of the material capabilities of a state in his analysis of inter-group relations. This points to Putnam's and Gourevitch's theories of two-level games, and also to the liberal theory of international relations, which stresses the importance of state actors in the formulation of a state's foreign policy: "[...] l'intérêt national des libéraux équivaut in fine à l'intérêt des acteurs sociétaux majoritaires. ${ }^{75}$

Much like Wendt in his constructivist theory, Huntington engages the structureagency debate in the analysis of international relations. He does so, actually, by mixing them up throughout his work, but especially so at key points of particular relevance to the current essay. While most of his arguments and concepts are of a structural nature (civilizations and their determining effect on international relations), he makes a number of claims that hint to the role of agency. The first one concerns the possibility that a given country might want to "switch" civilizations; ensues, according to the

\footnotetext{
73 Ibid., 139-140.

${ }^{74}$ Alexander Wendt, Social Theory of International Politics (Cambridge: Cambridge University Press, 1999), 185.

${ }^{75}$ Dario Battistella, Op. cit., 149.
} 
author, either acceptance or rebuffal from the "target civlization." The second 'claim' is tied to his prescriptive stance on foreign policy; the gist of his argument here is that decision-makers should be aware of the opportunities and pitfalls presented by a world of civilizations. ${ }^{76}$ This is where Huntington's theory becomes hybrid, crossing the theoretical boundary from structural realism to constructivism. Because, much like constructivism, Huntington cannot fully account for the role of agency in the international system (rather presenting it as a system being at the same time reflected and reflecting a country's foreign policy), nor can it fully account for the production of a state's identity.

These weaknesses are at the center of the constructivist project's shortcomings with regards to foreign policy analysis. ${ }^{77}$ There have been numerous attempts in the academic community to address those weaknesses in order to craft a more coherent framework of foreign policy analysis; some of these attempts are retraced here. First, Walter Carlsnaes who tried to resolve the structure-agency debate, and who came close to the model adopted in this essay. Carlsnaes, on the basis of constructivist theory, comes up with a 'model' in which the state (as defined in realism) is the agency of international relations, and therefore, of foreign policy; this agency would be limited by an otherwise malleable, yet undefined, international system. ${ }^{78}$ In this, there is no

\footnotetext{
${ }^{76}$ Samuel Huntıngton, $O p$ cit , 139, Chapter 12, my thanks to Cédric Jourde for having pointed out the second one

${ }^{77}$ Alex McLeod, «L'approche constructiviste de la politıque étrangère,» dans Frédéric Charıllon, Polıtıque étrangère Nouveaux regards (Par1s Presses de Sciences Po, 2002), 84-85

78 Walter Carlsnaes, "The Agency-Structure Problem in Foreign Policy Analysis," International Studies Quarterly 36, no 3 (Sept 1992), 257 This author is not certain, but it seems as if Carlsnaes equates the concepts of international relations and of foreign policy, or at the very did not find a specific delımitation between the two in Carlsnaes' article It should also be noted that this author perceives conceptual problems with how the term 'state', disconnected from institutional meanings, is used in the surveyed articles (not only
} 
significant movement away from constructivist theory, except for a greater role lent to discourse and institutions in foreign policy; what role this is, is left rather vague. A 'contextualized' type of foreign policy analysis is presented in Valerie M. Hudson's and Christopher S. Vore's critical review of recent approaches in the field; this approach was developed by Harold and Margaret Sprout. Two tenets of this approach are particularly interesting; they take of epistemological propositions: first, the analysis of foreign policy should take place on multiple levels and, second, it should be interdisciplinary. ${ }^{79}$ Marie-Christine Kessler delved into such an approach when she conceptualized foreign policy as but one of a country's public policies, which would in turn be affected by multiple internal actors (the passive form of the last part of this sentence is no coincidence or a strictly linguistic expedient). For Kessler, these actors would be as varied as social movements, interest groups, political parties, institutions, opening up the theoretical field to new horizons, mostly sociological ones.$^{80}$ This poses the question of poststructuralism's positioning within the foreign policy analysis debate.

On the flip side, poststructuralism has come under serious criticism by McLeod for the perceived fickleness or short-term nature of the socially-produced representations and identity as they are discussed in poststructuralism. ${ }^{81}$ Since foreign policy analysis, arguably, requires the possibility to conceptualize event in the longer

Carlsnaes), especially those in English. Due to the limited space avallable here, pursuing this argument in this essay is not possible, but might be done in a future article further detailing the epistemological/theoretical arguments raised in this chapter An illustration of the author's model would probably be useful in defining this dichotomy, but is, again, not possible to include due to time and technological constraints

${ }^{79}$ Valerie M Hudson and Christopher S Vore, "Foreıgn Policy Analysis Yesterday, Today, Tomorrow," Mershon Internatıonal Studies Review 39, no 2 (Oct 1995), 213-214, Willıam Carlsnaes, Op cit, 253

${ }^{80}$ Marre-Christine Kessler, $O p$ clt , 167-170

${ }^{81}$ Alex McLeod, $O p$ ctt , 86 
term, then poststructuralism would be unsuitable for such research. ${ }^{82}$ However, a few works situated within the poststructuralist paradigm (if it can be called that) demonstrate the incredible resilience that some of these representations can have, starting with Michel Foucault's Surveiller et punir. ${ }^{83}$ From a perspective that is more relevant for political science and international relations, David Campbell and Kennan Ferguson have written about the durability of cartographic, geographic, and geopolitical images. These, they have shown, have had either empowering or limitating effect on a specific state's foreign policy outlook (in the case of Imperial Britain and the post-Cold War United States, respectively). They also show how these images have served the state to justify its foreign policy to their own populations. ${ }^{84}$ This strongly suggests that poststructuralism provides a fuller explanation of the production of socio-political identities, which can be durable, and how even those domestic images can provide justification for foreign policies. ${ }^{85}$

On its own, poststructuralism cannot account for the full range of possibilities present in the international system because of its focus on the discursive creation of

${ }^{82}$ William Carlsnaes, Op cit, 263-264; Alex McLeod, Op ctt , 76-78

${ }^{83}$ Michel Foucault, Survelller et punir (Parıs: Éditions Gallımard, 1975), 24-32 What Foucault does in this work is to demonstrate how the definition of what is abnormal or otherwise punishable also defines what is to be considered normal in society $\mathrm{He}$ demonstrates that some of these representations come to us from as far back as the $17^{\text {th }}-18^{\text {th }}$ centuries

84 David Campbell, "Poststructuralısm", in Tim Dunne, Milja Kurk1, and Steve Smith, International Relations Theortes Discipline and Diversity (Oxford Oxford University Press, 2007), 203-206, Kennan Ferguson, "Unmapping and Remapping the World Foreign Policy as Aesthetic Practice", in Michael J Shapiro and Hayward R Alker (eds), Challenging Boundartes Global Flows, Territorial Identities (Minneapolis Unıversity of Minnesota Press, 1996), 165-168

${ }^{85}$ Lene Hansen, Security as Practice Discourse Analysis and the Bosnlan War (New York Routledge, 2006), 1, 9 Lene Hansen argues that poststructuralism, despite its lack of focus on causal analysis, qualifies as a theory according to the proposition put forward by Alexander Wendt that the theorization of the constructive relationship between structures and agents or identity and foreign policy is a valid aim of research (See Alexander Wendt, $O p$ cit, $\mathrm{p}$ 87) One could also argue that Huntington's Clash of Civilizations, even if it does not fully conceptualize this link between foreign policy and identity and broaches the topic almost by accident, could be called a theory according to this proposition 
reality. If one country or state discursively constructs its surroundings (foreign policy), then it only goes to say that other countries or states do the same (international system) ${ }^{86}$ The interaction of these discourses (international relations) will in turn shape the international system and give way to varied, open-ended outcomes. As Hansen points out, discursive activity is agency-based; poststructuralism, therefore, can account for the production of one discourse (focus of study). but cannot do so for all the interacting discourses in a single empirical research without endangering the principle of theoretical parsimony. ${ }^{87}$ However, it provides an answer to the all-important constructivist dilemma regarding the relative position of material and ideational factors vis-à-vis each other; constructivism does not indicate how to logically 'choose' an approach over another, since material factors are not really dissociable from ideational factors in trying to assess why a certain policy worked or not. ${ }^{88}$ Indeed, in poststructuralism, physical and material factors do not only have an independent existence, but are also shaped and given meaning, sometimes extraneous meaning, by discursive practices of pertinent agency; therein also lies the rejection of pure rationalism in favor of a recognition of a 'discourse of power. ${ }^{89}$

Owing to the discursive nature of foreign policy formulation, an activity therefore centered on agency, then the study of foreign policy needs to focus on that

\footnotetext{
${ }^{86} \mathrm{Ib} \iota d, \mathbf{p}$ 1, Marie-Christine Kessler, $O p$ cit, 169

${ }^{87}$ Lene Hansen, $O p \quad c t$, 1, James N Rosenau and Mary Durfee, "The Need for Theory", in James N Rosenau and Mary Durfee, Thinking Theory Thoroughly Coherent Approaches to an Incoherent World (Boulder Westview Press, 1995), 2 "It is impossible to perceive and describe all that has occurred (or is occurring), and there is just too much detail to depict every aspect of any situation, much less numerous overlapping situations."

${ }^{88}$ Darı Battıstella, Théories des relatıons internationales (Parıs. Presses de Sciences Po, 2006), 269

${ }^{89}$ Stephen K White, "Poststructuralism and Political Reflection," Political Theory 16, no. 2 (May 1998), 188
} 
agency. From one society or country to another, this agency can vary; how this agency comes to be 'selected' can also change depending on local cultural values. Despite a social context that can sometimes be loaded with different agency (social movements, interest groups, political parties, etc.), these would still need to be conceptualized as [partially] limiting structures on the foreign policy agency, even if it possible that this agency would have the power to also construct these structures through its discourse. Despite a research context where fully-fledged agencies might be conceptualized as structures, a theoretical framework wide enough to at least partially account for the interests and actions of these structures (for example, social movement theory). depending on the structures being studied (since neither poststructuralism nor constructivism make specific assumptions about the expected outcomes of agencystructure interactions). The basic model remains theoretically parsimonious: poststructuralism provides a way to study discourse; constructivism to observe international developments that are the result (or not) of that discourse; an extra body of theory to conceptualize internal structures. Graham Allison's bureaucratic theory could be of use to control for multiple agencies acting upon foreign policy formulation. Finally, it is argued that Putnam's theory of two-level games can be useful way to understand the need for a state to mediate the interests of domestic and foreign structures in its foreign policy.

For the purpose of this research, the agency studied, the agency responsible for the formulation and execution of Russian foreign policy is the Russian state, embodied in the institutions of the Ministry of Foreign Affairs, which is hierarchically subservient to the office of the head of state, the Kremlin. As this essay seeks to answer 
Huntington's implicit challenge with regards to Russia's foreign policy towards the Islamic world, it will be the controlling international structure. However, it will still be necessary to conceptualize the sources of religious identity in Russia. The authors presented in the aforementioned 'Echoes of Byzantium' argue that the Russian Orthodox Church has often been an influential institution in Russian society, and has sometimes been considered an alternative to the state at some points in history. Therefore, a brief survey of the assumptions present in theories of the sociology of religion is relevant, and is conducted in the next part of this chapter.

\section{RELIGION In A SOCIAL CONTEXT}

A piece of the puzzle is still missing in order to be able to fully account for the pressure put by Russian Orthodox Church on the determination of the Russian state's foreign policy agenda. The theoretical puzzle cannot be complete without accounting for findings in the field of the sociology of religion that will provide useful tools for the analysis of the case of the Russian Orthodox Church's relation to the state during Vladimir Putin's presidency, which will be discussed in the next chapter of this text. Two models will be considered in the current section: the possible application of worldsystem theory to the study of religious phenomena in society and how it ties into needs theory and Gramsci's theory of political sociology. ${ }^{90}$

\footnotetext{
90 Dwight B. Billings and Shaunna L. Scott, "Religion and Political Legitimation", Annual Review of Sociology 20 (1994): 192, 194; Jeffrey R. Seul, “'Ours is the Way of God": Religion, Identity, and Intergroup Conflict", Journal of Peace Research 36, no. 5 (1999): 554.
} 


\section{Religion Defining Identity}

World-system theory, as described by Billings and Scott, cannot properly explain the "global context of religious struggle," however, this shortcoming should not pose a problem in the current study since it aims to explain the lack of conflict or struggle (between Russian Orthodoxy and Islam), not its presence. The Marxist elements of the theory have been partially purged from the theory, focusing on "contexts" rather than on "classes", making it useful to study phenomena that are not economical in nature, as explained by Maduro: "[...] the religious area is always situated in a determinate social context that limits and orientates it, and hence renders the specific autonomy of religion relative to that context." ${ }^{91}$ Moreover, world-system theory allows for the superposition of the domestic/internal context with the international one, a dimension that is critical to the current study.

This will allow for a multi-level use of needs theory to explain the importance of official church institutions for the Russian state during the proposed time frame. Needs theory, in the context of this research, will focus on the parameters of individual and group identity. In other words, part of the questioning will center on the sense of security conferred by a solid individual identity when dealing with outside parties. ${ }^{92}$ Differing identities are the root causes of conflict according to both Samuel Huntington and John Anderson, so it will need to be shown exactly how identity conflicts break out and which factors need to be present. Moreover, it will be shown that, despite evidence that there is probable cause of conflict between Russia and Saudi Arabia or Iran, that the

\footnotetext{
91 Ibid., 192.

92 Jeffrey R. Seul, Op. cit., 554.
} 
strong identification with Russian Orthodoxy and the Moscow Patriarchate's interconnectedness with the state, no overt conflict has erupted in these two dyadic relationships.

Finally, Gramsci's model of political sociology will be looked at when conceptualizing the position of the church in Russian society. Indeed, while worldsystem theory makes it possible to study the position of the church in comparison to that of the state, and do so in a multi-level analysis, Gramsci introduces questioning about the motives of religious organizations, which for him is hegemony, into the theoretical mix, something that is absent from world-system theory. He also looks at the means used by religious organizations to propel themselves to power, at how their message is shaped and who it is addressed to. ${ }^{93}$ This aspect of the problematic is looked at in chapter 2.

Impossible to separate from the previous theories is Sherkat and Ellison's contention that "[r]eligious beliefs, commitments, and resources are an important part of building and maintaining ethnic identities, and they provide the ideological and actual resources brought to bear in ethnic conflicts ranging from the struggles over civil rights in the United States, to economic justice in Latin America, to Islamic and Zionist movements in the Middle East (Beyer 1994. Billings \& Scott 1994. Casanova 1994. Moaddel 1996. Smith 1996a)." ${ }^{\prime 94}$ This statement's significance for the current study cannot be underestimated, and will become obvious once a proper link will be

\footnotetext{
${ }_{93}$ Dwight Billings and Shaunna Scott, Op cit, 194

${ }^{94}$ Darren E. Sherkat and Christopher G. Ellison, "Recent Development and Current Controversies in the Sociology of Religion," Annual Review of Sociology 25 (1999): 369.
} 
established between the needs and multi-level game theories. It forms one of the main arguments of this research project, and will be further explored in the next two chapters.

\section{Pseudo-Religious Politics}

Some scholars readily associate religious activism with social movement theory. ${ }^{95}$ Since this is a recognized sphere of activity for religious organizations. this line of reasoning will be pursued in the current study, for a few reasons. First, social movements often make demands on the state concerning public policy, something that can influence a state's international bargaining. It is demonstrable that the Russian Orthodox Church could possibly function as a focus for social movements, or even as a social movement itself. Evidence exists to show it acted as an interest group treating its support base as the repository of its legitimacy (this will be demonstrated with Gramsci's political sociology theory), making it reasonable to apply certain elements of social movement theory to the current study.

The idea that religious social movements should form alliances once their goals are proven to be similar is of special interest, because it bears some resemblance to what happened in Russia during Putin's presidency, and would seem to tie into a part of a recent argument put forward by Anastasia Mitrofanova with concerns to Churches' political activities in Orthodox countries. While she acknowledges that Orthodox Churches are becoming increasingly active in politics, and that Russia has partly lost its

${ }^{95}$ Ibld , 370; Dwight B1llıngs and Shaunna Scott, Op cit , 173 
secular veneer as a result of this trend, she contends that religious organizations stand to lose some of their freedom to criticize the government by becoming too close to it. This last argument is not without merit, but ignores the fact that the Church, at least in Russia's case, already has pledged not to position itself politically in relation to the state, rather preferring cooperation with executive organs on matters of mutual interest. ${ }^{96}$ Lastly, Mitrofanova suggests the term "civil religion" to describe the process of the de-secularization of the state in Russia during Putin's presidency, stating that "[u]nlike political religions, civil religions aim not at reaching religious goals using political means but at the sacralization of the state and its institutions. ${ }^{97 " ~ A c c e p t i n g ~ t h i s ~}$ basic principle, this study shows, in more detail in the following chapters, how the Russian Orthodox Church and the state have become enmeshed, and what are the benefits of this alliance for the latter, especially with regards to its foreign policy with Islamic states, which, according to, amongst others, Huntington and Anderson, pose an implicit threat to Russia because of a "civilizational" or identity gap. This idea about the growing association of the Church and State in Russian society is examined in greater detail in the next chapter, Dreams of Symphonia.

\footnotetext{
96 РПЦ, «Церковь и политика,» Основы соииальной концепции Русской Православной Церкви (2000), www. mospat.ru (accessed 24 January 2009).

97 Anastasia V. Mitrofanova, Op. cit., 176.
} 


\section{Chapter 2: Dreams of Symphonia}

A quick look at statistical figures leaves no doubt as to the privileged position of the Orthodox Church in contemporary Russian society. Such a look constitutes the first part of the current chapter, in which the techniques used by the Orthodox Church to favorably position itself vis-à-vis the Russian state apparatus will be analyzed from the viewpoint of the theories exposed in the previous chapter. In other words, the study of the influence of religious authorities on temporal institutions in this chapter constitutes the first part of the multi-level analysis (on the domestic level) that is to be completed by a contrasting study of the outcomes of these maneuverings on the international stage (focusing on the OIC) in the next chapter.

The second part of this chapter offers an in-depth analysis of the documents published by the ROC to clarify its political agenda. The foremost of these documents is the Social Concept of the Russian Orthodox Church, published in 2000. It has been referenced in studies of the role of the Moscow Patriarchate in Russian political life, but has not truly been given all the attention it deserved when it comes to the execution of foreign policy. Indeed, it will be demonstrated that the Social Concept contains several articles pertaining to the Russian state's foreign policy, and how it should conduct this foreign policy in consultation with the Church. A value system that should guide the state in its exterior relations is also set in place, with instructions on how to behave within international organizations. These are outlined throughout multiple chapters, more specifically those relating to the Church's involvement with the nation, state, and with issues of international relations (and therefore foreign policy) themselves. These 
will be discussed in more detail in the following sections of this chapter, but first, evidence of the prominent role of the Moscow Patriarchate in contemporary Russian society will be presented.

\section{ASCENSION OF THE CHURCH}

Weathering the secularizing storm of Communist ideology, the Russian Orthodox Church saw the number of its adherents swell in the years after the Cold War. Whether the flight was provoked by believers going underground or having been persuaded to toe the official party line, most of them flocked to the Church in droves when freedom of religion was restored in the last years of the Soviet Union. Both statistical and qualitative data point to the resurgence of religious identity, and they are looked at in the first and second section of this part, respectively.

\section{The Figures of Religious Identity}

A poll conducted in 2001 puts Orthodox self-identification in Russia at $73 \%$, nearly three-quarters of the population. ${ }^{98}$ Whether or not this translates into high levels of participation in liturgical services does not truly matter since, by those numbers, the ROC can already profess to represent a large majority of Russia's population, granting it the weight and legitimacy needed to push forward their political agenda. This confirms the ROC's belief that Russia is its "canonical territory." 99

\footnotetext{
98 Paul Anderson, Op. cit., 191.

${ }^{99}$ Ibid., 192.
} 
Further evidence of the Church's prestige can be found in the annual survey in which Russian celebrities are ranked according to their popularity; it can be found in PolitKlass, a Russian political commentary monthly. In ten years' time, that is to say from 1998 to 2008, former Russian Orthodox Patriarch Aleksy II quickly made his way to the top of the charts. starting from a tie in the last position in 1998 to a very comfortable $7^{\text {th }}$ place (out of 20 ) in the 2008 survey; ${ }^{100}$ he was outranked only by the usual suspects, that is to say the new prime minister (Putin), the president, and his top advisers, ministers, and Moscow's mayor. As will be discussed in the following part, this increase in popularity was not preordained, but was rather earned by the patriarch through his uncanny ability to thrive on the political heights.

This, in itself, does not fully explain the ability of the Church to favorably position itself to influence the governmental agenda, directly or indirectly. After all, these figures are but indicators of a passive acceptance of the renewal of the Church's role in society, but not of its actual presence and/or participation in the political debate. It does happen that religious figures do not make for skillful politicians, but it is important to see why this could not be said of Aleksy II, the late patriarch of Russian Orthodoxy during Putin's presidency.

100 This survey is compiled by Vox Populi - $T$ for the Independent Editing Group (Независимая Издательская Группа, ww.w.nigru.ru) and reflects the assessment of leading Russian journalists and political experts of a personality's influence according to their political activity and the coverage these activities have generated within a time period. The survey is updated every month, and has been compiled in this way since 1993. The survey includes 100 personalities, but is only partially reproduced in the monthly PolitKlass, which presents only the top 20 ranks of the surveys. See: НИГ, «100 политиков России в июне 2010 года,» Независимая издательская группа (20 July 2010), http:/www.nigru.ru/docs $9 / 2561 \mathrm{hlml}$ (accessed 29 July 2010). 


\section{Making the Front Pages}

Beyond Aleksy II's profile as a former KGB agent ${ }^{101}$ (which makes him a natural interlocutor to Putin), he proved himself an apt mediator during high-profile crises related to the transition from communism. His prominent role in the resolution of the siege of the White House by the State Emergency Committee in August $1991^{102}$ most definitely increased his prestige within the Russian intelligentsia, and that not only within the confines of his usual role as head of the Church, even if this ascendancy in public opinion took place over a whole decade (as is showed in the previous section). What is crucial is that Aleksy II had the willingness to use this political prestige not only to boost the number of parishioners at Sunday mass (which, if it is the case, is a relative failure), but also to aggressively push for the Church's agenda to be taken in consideration by both state and society, something he accomplished to a greater extent.

Over the years, this influence was not necessarily direct, and its results were not always well received by the larger public, who did not always approve of the attitude and certainly not the policies - the state adopted towards the Church ${ }^{103}$ However, it provided a way for the Church to achieve a rapprochement with the state and securing the means by which it would become stronger than organizations and interest groups of other religious affiliations, all the while garnering publicity in the press for its tour de force. And that it is, since this allowed the Church to put itself where it became not

101 John and Carol Garrard, Op clt , 20.

$102 \mathrm{Ibld}, 18-27$. Patriarch Aleksy II, after a direct appeal of help from Yeltsin, appealed to multiple sectors of Russian society, including the army, to act according to the principles of morality and law. His appeals, delivered in liturgical language, were heeded by the besiegers of the White House who refused to obey the KGB's orders. This precipitated the coup's fallure.

103 Alexander Agadjanian, $O p \quad c t$, 358 Agadjanian cites one example where the press reported on the Church receiving unofficial tax privileges from the state. 
only a part of the political discourse, but one about which people found themselves divided across a spectrum that included supporters in addition to opponents, much like a regular political formation. ${ }^{104}$ Other consequences and impacts of the Church's greater involvement in politics are observed in the next section of this chapter.

Despite this newfound presence in social debates, the Church still had not given a clear indication of what it aimed to achieve beyond a strengthening of the religious values of society. In other words, it had not announced what it intended to truly use its political leverage for. Its most noticeable effort to do so to this date is the Social Concept of the Russian Orthodox Church, published in 2000. the same year Putin started his two-term presidency. An in-depth discussion of this text follows in the next section.

\section{TEMPORAL INVOLVEMENTS}

The Church, by publishing a clear manifesto of its beliefs and intentions relative to political actors in Russian society seeks to maximize its political leverage to influence the definition of the governmental agenda. The document, fittingly, is called the Social Concept of the Russian Orthodox Church, and was published in 2000, at the outset of Putin's two terms in the presidential office.

Through the document, the Church sets multiple objectives for itself, in various fields of endeavor. While they will not be reproduced here, it is worthwhile to note that most of the topmost objectives are relevant to foreign policy or international relations.

104 Ibid., 358-359. 
while only those at the bottom of the list are connected to usual fields of preoccupation for a religious organization (such as broad categories of social policy such as health and education). ${ }^{105}$ Meanwhile, most of those objectives are explained and given a detailed presentation in separate chapters - themselves separated in articles - that read like a constitution. Six of the sixteen chapters establish a role for the Church in matters closely related to identity, politics and international relations. Due to the wide array of principles enunciated in the document, only a handful of articles of particular relevance to the current argument have been selected for a deeper analysis.

The articles selected belong to three chapters of the Social Concept, and will be studied here according to two main distinctions: those that have to do with international affairs (taken from Chapter 16, titled International Affairs and Globalization), those that are related to matters of nation and identity, as well as Church-State relations. Their selection is obvious, as they refer to the two-level game that has been discussed in chapter one, and can both be linked to Huntington's theory of the clash of civilizations, that is the starting point of the current argument. For this reason, links between the articles and the theoretical framework elaborated in chapter one are established in the third part of this section. The analysis unfolds in three parts: first, by a critical review of the Social Concept, and then, by linking the not-so-religious document with recent developments in Russian society and politics. The third part of the analysis introduces the theoretical discussion of chapter one into the current debate

105 РПЦ, «Церковь и государство,» Основы сочиальной концепщии Русской Православной Церкви (2000), www.mospat,ru (accessed 24 January 2009). A translated version of the list can be found in John and Carol Garrard, Op. cit., 243-244. 
so that the argument about the influence of the Russian Orthodox Church in foreign affairs can be completed in the next and last section of this chapter.

\section{New Scriptures}

Issuing political manifestoes. Anastasia Mitrofanova notes, is more and more common for Orthodox Churches. ${ }^{106}$ Multiple organizations and special interest groups that are not ordinarily involved in politics have also taken up the practice of producing such documents. While this is rather common, they generally promote specific aims directly related to the organization's work, and they use mild, inoffensive language.

Even though the Social Concept of the Russian Orthodox Church, by and large, does not detract from this usage, pronouncing the equality of nations and denouncing wars of aggression, as one would expect. However, it is striking for the tone it uses, its broad scope, and its inclusions and sometimes even omissions. Indeed, the Social Concept establishes a large number of areas as being of concern to the Church. including issues of nationality, politics, relations with the state, and international relations that are often thought about in the West as being irrelevant for religious organizations. The Russian Orthodox Church, however, ignores the taboo and forcefully sets its positions in those fields. Moreover, it would be thought that such positions would be expressed from a supranational point of view. Yet, the Church's context, different from that of the

Roman Catholic Church or the more clerical movements in Islam, transforms the

106 Anastasia Mitrofanova, Op. cit., 173. 
exercise in a radical endorsement of state-centric principles (principles, of course, that are a cornerstone of Russian foreign policy). ${ }^{107}$

With regards to international relations, the Church's views are somewhat cryptic, preferring that the state keeps as little involvement in cultural organizations as possible, and that it compromises even less on most issues regarding its interests, identity, and that of the Church. To keep that from happening, the Church suggests that the government should consult with it on these matters, even proposing that they should. along with other international and national bodies, work in unison to prevent the effects of globalization, which, according to them, will lead to a general loss of identity. In other words, this could mean that the state should ensure the preservation of the status quo when it comes to the balance of powers (understood as the allocation of tangible and intangible resources) within the domestic political system (or, among identity groups).

This issue of Church-state relations, and consultations of one with the other, is the most astonishing part of the Social Concept. Three articles are particularly remarkable, and they deal with the intrinsic fact of the cooperation between Church and state.

107 РПЦ, «Международные отношения и глобализация,» Основы сочиальной конуепции Русской Православной Церкви (2000), жжж.muspal.ru (accessed 24 January 2009); Article XVI.1. It is explicity stated a number of times throughout the Social Concept that the Church supports the double principles of state sovereignty and territorial integrity, and these are even compared to the Christian principle of the absoluteness of God. 
Not only does the Church bluntly and without substantial justification assumes the right and necessity to 'enter in contact with executive bodies' of the government, it also states that it 'remains loyal to the state', but that 'this loyalty is subordinated to that for the holy commandment' and that 'the Church will pursue its missions under any conditions or circumstances'. ${ }^{108}$ This alone is not cause for concern about the encroachment of the Church on the state, but what precedes it by a few articles tops off the list:

According to the teachings of the Church, authority itself does not have the right to become absolute, extending its limits to full autonomy from God and His established order of things, which could lead to misuses of power and even to the deification of leaders. ${ }^{109}$

This passage suggests that, at the time of the Social Concept's publication, a formal confusion of Church and state powers existed, and that this link shall not and cannot be unilaterally broken by the state. This, coupled with the broad, undefined mandate undertaken by the Church through its Social Concept, is the basis for its involvement in temporal affairs.

Now, were it not for substantial evidence that the Church is deeply influencing, if not interfering with, the state, the Social Concept would not be cause for concern. It would certainly not be the first time a special-interest group or a social movement released an ambitious statement of purpose, but be unable to carry it through. Here, this

108 РПЦ, «Церковь и государство,» Основы социальной кониепџии Русской Православной Церкви (2000), мхw.mospatru (accessed 24 January 2009); Article III.5. «Церковь сохраняет лояльность государству, но выше требования лояльности стоит Божественная заповедь: совершать дело спасения людей в любых условиях и при любых обстоятельствах.»

${ }_{109} \mathrm{Ibid}$, Article III.2, «По учению Церкви, сама власть также не вправе асболютизировать себя, расширяя свои границы до полной автономии от Бога и установленного Им порядка вещей, что может привести к злоупотреблениям властью и даже к обожествлению властителей.» 
is not the case. Ample evidence suggests the concerns of the Church, at least during Vladimir Putin's terms as president from 2000 to 2008, were foremost in the state's legislative agenda and policies throughout the studied period. Some of this evidence is presented in the next part.

\section{Liturgy for the People}

The impacts of the Church's involvement in public affairs and discourse cannot be fully ascertained if one does not look to the Russian media for such confirmation, and to some of the general political developments that generated the media criticism in the first place. Two of these 'events' have already been covered, that is to say, the ascension of former Patriarch Aleksy II from a fringe political figure in 1998 to one of the most popular in 2008, and the publication of the Social Concept in 2000. Multiple others are worthy of attention, but three particularly are: the publication of the National Security Concept of the Russian Federation in 2000; the signing of an agreement between the Russian Orthodox Church and the Ministry for Foreign Affairs in 2003; and the publication of multiple articles assessing the role of the Church in contemporary society in the Russian monthly PolitKlass in 2008.

Indeed, in the course of 2008, several articles appeared in the monthly PolitKlass, denouncing or supporting the Church's role in society, with one author going so far as saying that the only way to avoid, or at least dampen. the occurrence of human mistakes was to move towards a society that is more structured by religious values, organized by 
the Church. ${ }^{110}$ This was, however, a dissenting voice, with other authors denouncing the "clericalization" of Russian society, called "evident" as "every project of law of any importance being the subject of Church involvement at every level," as being a movement supported by nationalists and conservatives (the stream to which Putin belongs), and ultimately only opposed by liberals. ${ }^{111}$ The most eloquent comment on the Church's current strength is by far the following:

In contemporary Russia [...] the Orthodox Church has transformed itself into a powerful structure, intimately linked with all branches of the state apparatus, with all fundamental parties; it controls enormous material resources, actively influences social opinion. ${ }^{112}$

So, without a doubt, the Church has an established role in Russian politics and social life since 2000. This role was further strengthened in 2003 by the signing of an agreement of understanding between the Church and the Ministry for Foreign Affairs. ${ }^{113}$ Regretfully, it proved impossible to obtain a copy of this document for further analysis. This was already partially true in 2000 , when the newly published National Security Concept of the Russian Federation was released. It contains references to the need for 'furthering the Orthodox development' of the Russian state. While it may seem like a statement devoid of any meaningful intent, it is interesting to note that this addition to

110 Руслан Аврамченко, «Обществу нужна массовая Церковь: Светская парадигма религиозной культуры», Политический Класс 44 (August 2008), wи и politklass.ru (accessed 3 October 2008).

111 Аркадий Малер, «Рождение православного проекта», Политический Класс 41 (Мау 2008), n w w politklass.ru (accessed 15 March 2009). «Однако по прошествии времени, особенно в 2000-е годы, социальная активность Церкви стала очевидной, когда ни одно более-менее значимое мероприятие государственного уровня не обходилось без заметного присуствия священнослужителей начиная с самого патриарха, а по тем или иным вопросам, иногда самым неожиданным, церковь вдруг заявляла свою особую позицию.»

112 Александр Бузгалин, «Церковь, общество и нравственность», Политический Класс 45 (2008), wwx.politk]ass.1u (accessed 15 March 2009). «В современной России (...) Православная Церковь превратилась в мощную структуру, тесно сращенную со всеми ветвями государственной машины, со всеми основными партиями, она контролирует огромные материальные ресурсы. Активно влияет на общественное мнение.»

113 John and Carol Garrard, Op. cit, 249. 
the National Security Concept was made in the same year the Social Concept of the Church was released, and also the same year in which, according to journalists and other observers of Russian politics, the involvement of the Church in temporal affairs became 'evident' (see the reference to Maler's text on the previous page).

The President, the Patriarch, and the Holy Ghost

This influence stems partly from high-level contacts between the Church and state, that is to say, between Putin and Aleksy II. During those meetings, the timing of which often correspond to Orthodox holidays such as Christmas, Easter, or Thanksgiving, Putin has repeatedly made statements pertaining to the Church's role not only in socio-cultural affairs, but also in foreign policy matters. An examination of both of those types of statements is important to the development of the present argument.

Some of those strongest statements on the former president's part were on the matter of the Church's legacy to the Russian nation. While, again, these statements might be construed as a form of polite recognition, the Russian context of the last 20 years lends them special resonance. This is particularly true, since they also contribute to the reinforcement of the legitimacy of Aleksy II's involvement in state affairs. On the occasion of several of those meetings, Putin has affirmed the Church's role in the establishment of Russian statehood and the preservation of Russian cultural and spiritual traditions. Despite sometimes using the terminology rossiiskiy (Russian in a civic rather than cultural sense) to refer to the second part of the Church's role, this leaves no doubt as to the true meaning of those words, which equate culture and 
statehood (a partial rejection of Russian multiculturalism). Moreover, Aleksy II's personal contribution to the development of the Church is underlined in no uncertain terms. ${ }^{114}$ Knowing full well the deciding role Aleksy II played in saving Yeltsin in 1991 (to whom he owes his own political stature), Putin probably realized he would be enhancing the patriarch's stature in the political system through personal and emotional praise for his public achievements.

This is likewise reflected in the leadership position accorded Aleksy II when meeting with religious leaders abroad, or even acting upon matters of the Moscow Patriarchate's self-interest, such as the reunification of the domestic (Russian) and foreign branches of the Russian Orthodox Church. On this particular matter, Putin involved the state apparatus to achieve goals of a religious nature (unification of the Church), possibly to preserve the principle of the Ministry of Foreign Affairs' primacy in coordinating the international activities of the Russian Federation. ${ }^{115}$ But, it can also be interpreted as a completion of the cycle started when Aleksy II intervened on Yeltsin's behalf during the August 1991 crisis. Moreover, it bears noticing that there have been a few occasions where one of Putin's visits abroad was followed by meetings with Aleksy II, only to extend an invitation from the same interlocutor to the Patriarch, a

\footnotetext{
114 Кремль, Начало встречи с Патриархом Московским и всея Руси Алексием II в связи 45-летием его архиерейской хиротонин аnd Выступление на торжественном приеме по случаю восстановления единства Русской православной черкви аnd Выступление на встрече с иерархами Русской православной черкви по случаю 90-летия восстановления патриариества (Москва: Президент России: Официальный Сайт, 3 September 2006, 19 Маy 2007, 19 November 2007), archive.kremlin.ru (accessed 29 July and 10 August 2010).

115 Кремль, Выступление на торжественном приеме по случало восстановления единства Русской православной черкви (Москва: Президент России: Официальный Сайт, 19 Мау 2007), archive.kremlin.ru (accessed 29 July 2010); Кремль, Выдержки из стенографического отчета о заседании Государственного совета по проблемам внеиней политики России (Москва: Президент России: Официальный Сайт, 22 January 2002), archive.kremlin.ru (accessed 10 August 2010).
} 
salutation, or even an allusion to the Russian state's and Church's common interest in the country discussed. ${ }^{116}$ Even detached from the particular goals and objectives pursued by these visits, one can only accept that Putin himself, as president, supported and buttressed a foreign policy role for the Church.

This is partly true in the case of the Church's reunification with its branches outside of Russia. In this case, the Church's purpose in foreign policy would be that of an extension of domestic policy. This is evidenced by Putin's statements both at the time the Church's reunification was formally celebrated (in 2007), with the president and the patriarch both present, and on the occasion of the president's Addresses to the Federal Assembly from 2005 to 2007, but especially in 2006. That year, he discussed the issue of immigration in relation with Russia's relative demographic decline. He suggested it was important for Russia to attract more migrants from abroad, and in doing this singled out those who had a previous knowledge of Russian culture and tradition. ${ }^{117}$ He had already linked the Orthodox Church to Russian culture and traditions on other occasions (this is discussed above), but on the day the Church's reunification was celebrated, Putin made allusions to the issue of demography and migration. More specifically, he mentioned the historical reasons for the Church's initial splintering, that is to say the events that had forced some Russians to leave the

\footnotetext{
${ }^{116}$ Кремль, Начало втречи с Патриархом Московским и всея Руси Алексием II (Москва: Президент России: Официальный Сайт, 13 August 2004 and 23 February 2006); Втреча с Патриархом Московским u всея Руси Алексием II (Москва: Президент России: Официальный Сайт, 15 October 2003) archive.kremlin.ru (accessed 31 July 2010).

117 Кремль, Послание Федеральному Собранию Российской Федерачии (Москва: Президент России: Официальный Сайт, 10 May 2006) archive.kremlin.ru (accessed 31 July 2010).
} 
Motherland "against their will" and were "scattered all over the world. ${ }^{118 "}$ In that way, Putin gave some indications of what the Russian state might be gaining by reestablishing formal contacts with the Russian Orthodox diaspora: a pool of culturallysensible immigrants wishing to effect a return to the Motherland. Of course, these are only allusions, and one would need to look more closely at the Russian state's immigration policy to determine whether this support given to the Church's reunification inscribed itself in a wider immigration policy. But, the question itself is interesting, and provides a dimension to consider in the case studies of Russia's relations with the Islamic world: is there a propensity for religion to be a foreign policy instrument when the goal of a particular policy is to support a domestic initiative?

Another sign that President Putin supports a foreign policy role can also be found in relation with Russia's decision, what is described as one of President Putin's initiatives in official communiqués, ${ }^{119}$ to join the Organisation of The Islamic Conference as an observer-nation. In a meeting preceding the actual recognition of Russia of this new role within the OIC by two years, Putin thanked Aleksy II for his

\footnotetext{
118 Кремль, Выступление на торжественном приеме по случаю восстановления единства Русской православной черкви (Москва: Президент России: Официальный Сайт, 19 May 2007), archive.kremlin.ru (accessed 29 July 2010).

119 МИД России, Вытупление Министра иностранных дел России С.В.Лаврова на 32-й Конферениии министров иностранных дел стран-членов ОИК, Сана, 29 июня 2005 года; Интервью Министра Иностранных дел России С.В.Лаврова, опубликованное в арабском журнале «Аль-Ватан Аль-Араби»; Заявление Министерства иностранных дел Российской Федерачии в связи с объявлением о представлении России статуса наблюдателя в ОИК; Заключительное коммюнике первой встречи Группы "Стратегическое видение: Россия - исламский мир» (Москва: Министерство Иностранных дел Российской Федерации, 29 June 2005, 29 June 2005, 2 July 2005, 31 March 2006) wщw.mid.ru (all accessed 31 July 2010).
} 
ascent in allowing this development. ${ }^{120}$ Again, on this matter, Putin knowingly lends a role to Aleksy II for the completion of this policy initiative, and abandons even the pretense to his or the state's independence in reaching this momentous decision. At least when it comes to appearances and perceptions, Aleksy II's stature was elevated. But what does this mean in larger, theoretical terms?

\section{Revelations}

This suggests the following development took place over the late nineties and was confirmed in the early 2000 s by a formal, if not official, merging of opinions between the Church and the state. This partial transformation of Orthodoxy into a "civil religion" came to signify a de facto alliance between state and Church along the lines described by Sherkat and Ellison, where "[r]eligious beliefs, commitments, and resources are an important part of building and maintaining ethnic identities, and they provide the ideological and actual resources brought to bear in ethnic conflicts [...]."121 While this definition can be interpreted negatively, lending to religions a fundamentally "conflictual" nature (as is the case in Huntington's theory), other interpretations exist, that which will be explored further now. The current situation in Russian politics is one where symphony, understood in the Byzantine sense, has not only been achieved, but surpassed in favor of a state of organísm, as described by Agadjanian ${ }^{122}$ :

This organic way certainly means a religious one, in one way or another. In this discourse organic is the positive euphemism for "traditionalist."It refers

\footnotetext{
${ }^{120}$ Кремль, Встречи с Патриархом Московским и всея Руси Алексием II (Москва: Президент России: Официальный Сайт, 15 October 2003), archıve kremlın ru (accessed 31 July 2010) At this point, Russıa was only to join the meeting of the OIC's heads of state and government as a 'guest'.

${ }^{121}$ Anastasia Mitrofanova, $O p$ clt, 176 ; Sherkat and Ellison, $O p$ ctt, 369

122 Alexander Agadjanian, $O p$ clt, 362.
} 
to the Romantic allegory of a nation (or culture) as an organism, which was widely used by the Slavophiles in the 19th century. If a nation is an organism it must keep its integrity and its identity, consolidated by the "national idea." Orthodoxy naturally provides it with cognitive and symbolic material, eventually making the life of the nation organic and thus legitimate.

While Agadjanian links the benefits of 'the organic way' to those of legitimacy, and therefore domestic governance, it is possible to link it with how the state conducts its international relations as well.

As has been discussed in chapter 1, the constructivist and liberal theories of international relations, to different degrees, link the foreign policies of states to the interests of the most powerful actors of society (intrinsically for the liberals and through the promotion of their ideas for the constructivists), which always have to been considered by the state in order to conserve support for their domestic rule. However, in cases where the domestic organization (such as the Russian Orthodox Church) does not have a strong international reach, it might be satisfied with concessions from the state on the domestic front. It does not necessarily mean that the state, in turn, does not benefit from this dynamic when entering into negotiation with other countries. In Russia's case, this means that the Russian Orthodox Church, having achieved the status of a hegemonic organization in Russian society (up to seeing the country as its 'canonical territory'), defines Russia's character as being intrinsically Orthodox, and identity it buttresses and defends with the knowing support of the state. This is also reflected by the statements and policies of the state, which reinforces this idea of a confusion between Orthodox religion, Russian culture, and the state (while not 
necessarily meaning a violation of the constitutional principle of the separation of Church and state).

This was shown to be the case even in foreign policy, corresponding to the liberal theory's predictions that a state's international activities will be a reflection of the interests of the principal domestic agencies (or political actors, if not parties). The evidence presented in this chapter shows that the Moscow Patriarchate is one such agency. And, like Putnam predicted, this interplay affected both levels of negotiation for the state. The Russian state, through Putin's statements, enhanced the Church's stature and legitimacy when dealing with matters of public policy, and this in a very explicit way. ${ }^{123}$ In turn, this influence is used by the Church to seek support from the state on religious matters, and sometimes is given a consultative role, or even an active one, with concerns to unrelated issues.

\section{AN EPIPHANY}

Only this does not fully explain Russia's current behavior towards Islamic states, and how these relations are influenced by the Orthodox Church's predominant role in Russian society. After all, Russia still recognizes Islam as one of its four legal religions, ${ }^{124}$ has a handful of ethnic republics that are defined by their attachment to Islam, one of which it is trying to hang on to in the context of two previous civil wars and multiple

\footnotetext{
123 Кремль, Выступление на торжественном приеме по случаю восстановления единства Русской православной черкви (Москва: Президент России: Официальный Сайт, 19 Маy 2007), archive.kremlin.ru (accessed 31 July 2010).

124 Michael Bourdeaux, "The religious maelstrom of modern Russia", The Times (8 July 2006) www. timesonline, cu.uk (accessed 24 August 2010).
} 
terrorist acts associated with this struggle. Most tellingly for international relations, Russia joined the Organisation for The Islamic Conference as an observer-nation in 2005. which would appear to cement the Muslim identity of a part of its population. It also puts Russia in a position where it shares a forum with many countries of differing identities (even among those sharing Islam as a majority or even state religion), some of which are considered radical in most parts of the world. If Huntington would be right, the Russian state's strong identification with Russian Orthodoxy would and almost should provoke crises or even conflicts with Islamic states. Seeing this gloomy prediction never was fulfilled, it is interesting to examine how the strength of a system of belief could be said to have prevented conflicts between what some have termed natural enemies. This is the object of the next chapter, which will be followed with specific case studies to demonstrate the validity of the argument. 


\section{Chapter 3: Showcasing a Minority}

In 2005, Russia officially joined the Organisation of The Islamic Conference as an observer-nation. According to the description published on the website of the Russian Ministry for Foreign Affairs, the OIC aims at the "reinforcement of Islamic solidarity, the consolidation of the efforts of Islamic states working towards solutions to contemporary problems for the interest and benefit of Islamic peoples." ${ }^{125}$ At first glance, those goals do not seem to be in the Russian state's interest, since they would inevitably lead to the strengthening of Muslim interests within the federation (e.g. more autonomy for some of the autonomous republics, such as Tatarstan and Chechnya) and this, despite a strong identification of the state with Russian Orthodoxy. This is more than theoretical: as was pointed out in the previous chapter, the National Security Concept of the Russian Federation of 2000 sets out the strengthening of Orthodoxy as one of the goals that should be pursued for its ongoing security, whereas one would think this aspect would have to be played down if Russia wanted to expand relations with the Muslim world.

The discussion about Russia's positioning within the OIC will be made in three parts, each drawing on the excellent scholarly study of the question published in 2004 by Shireen Hunter, as well as on new political developments that have unfolded since this study. This is meant to bring a contrasting, sometimes refined, interpretation the new research material allows for. The first section of this analysis will begin by a

\footnotetext{
125 МИД России, Организачия Исламская Конференчия (Справочная информачия) (Москва: Министерство иностранных дел Российской Федерации, 17 August 2006), www.mid.ru (accessed 24 January 2009).
} 
reassessment of official discourse about Orthodoxy with regards specifically to Russia's new status in the OIC. It will be followed by an evaluation of Russia's Muslim minority's role in bringing about a rapprochement with Muslim polities. Finally, the chapter will be closed by setting out the general (both theoretical and practical) elements to be considered in the foreign policy cases that will be studied in chapters four and five.

\section{THE REVERBERATIONS OF IDENTITY}

Former President Putin, in his first Addresses to the Federal Assembly (Послание Федеральному Собранию), made little to no mention of Russia as a multicultural country, much less a multi-confessional one. Even when discussing the Chechen conflict, he never once mentioned the Islamic beliefs of the autonomous republic's population. In fact, on the $30^{\text {th }}$ of August 2002, during the Third International Congress of Tatars, he referred to the link existing between Tatarstan and the rest of the country as one between Slavic and Turkic peoples. ${ }^{126}$ This emphasized the ethno-linguistic rather than religious character of Russia's diversity. In her study, Shireen Hunter finds that Putin has an "ethnocentric tendency with elements of traditional nationalism" that accorded some prominence to its religious aspects. ${ }^{127}$ While she backs her statement with convincing evidence, the years of Putin's second term as president offers the possibility to make an even stronger case supporting this.

\footnotetext{
${ }^{126}$ Кремль, Выдержки из беседы с председателями делегачий III съезда Всемирного конгресса татар (Казань: Президент России: Официальный сайт, 30 August 2002) archive.kremlin.ru (accessed 10 August 2010).

127 Shireen Hunter, Op. cit., 194-195.
} 


\section{Patronizing the Church}

Besides the fact that Putin attended church services on multiple occasions, his official speeches are informative as to his attitude towards the Orthodox Church. These can also be taken as a safer barometer of Putin's self-identification as an Orthodox in his presidential capacities, rather than only as a private citizen. Moreover, the Addresses to the Federal Assembly, and other similar documents, can be understood more clearly as being instructions for the public service and other state organs, such as the federal legislature, to act upon the President's political program. What is important to find out while examining the Federal Addresses and other official documents and transcripts is whether there is evidence of a change of attitude by the President about Russian Orthodoxy's role in society. A quick survey reveals a change of tone in those words, relating both to his presidential addresses and to how the public proceedings of his meetings with Aleksy II were released, so it bears analyzing the possible implications of this change of tone.

Since Putin's Addresses to the Federal Assembly (from now on: addresses) certainly have a higher profile than his declarations for meetings with Aleksy II, and have a more specific object of analysis, they will be examined first. Indeed, in the addresses from 2001 to 2004, inclusively, Putin does not mention anything that has an overt cultural connotation. The year 2005, when Russia officially became an observernation in the OIC, marks a radical departure from this practice that endured in 2006 and 2007. For example, in 2005, he made a strong stand against the encroachment of religion on governing structures, saying that the state will oppose any illegal pursuit of 
national and religious interests, amongst others. While this could be understood to target the Orthodox Patriarchate, statements he makes in 2007 disprove this. Then, he calls "pernicious [...] foreign financing [that has] the intent of internal interference," saying this only "stokes interconfessional conflict." ${ }^{128}$ This cannot target the Moscow Patriarchate, since its international efforts are abetted by the state. ${ }^{129}$ It is hard to say with certainty which organizations Putin targeted with those words, but it is certainly possible that he was referring to the funding of radical Islamist organizations in Chechnya, a point that will be further discussed in Chapter Four.

On multiple other occasions during these two speeches, Putin closely links the ideas of Russian culture (and its religious facets) to Russian statehood. In and of itself, this is perfectly understandable coming from a country's head of state, and the more so in 2007, which was the year celebrating the Russian language. When he does so while seemingly forgetting to recognize the country's multicultural heritage, it becomes more problematic. Putin indeed used the singular form each time he spoke of tradition and nation (наш народ). Very little room was left for self-identification for Russian Muslims when Putin stated, in 2005: "Russia was, is, and will be a great European nation." One could understand that Putin believes that the Russian state is intrinsically linked with

128 Кремль, Послание Федеральному Собранию Российской Федерачии (Москва: Президент России: Официальный Сайт, 26 April 2007) archive.kremlin.ru (accessed 31 July 2010).

${ }^{129}$ Кремль, Выступление на торжественном приеме по случаю босстановления единства Русской православной церкви (Москва: Президент России: Официальный Сайт, 19 Мау 2007), archive.kremlin.ru (accessed 31 July 2010). 
Orthodoxy on the basis of identity. In other words, that the two are fundamentally inseparable or, if so, only institutionally, constitutionally. ${ }^{130}$

And that would be his European nation and Aleksy's, with whom Putin seemed to have a warmer relationship since 2004-2005. While earlier transcripts of their meetings (or the beginnings thereof) sometimes do not even show Aleksy's words. In the later years, the meeting looked more informal, more relaxed, with Putin and Aleksy sharing words like old friends, with one transmitting invitations from foreign dignitaries to the other (where each is on this line of transmission was discussed in chapter 2). And these meetings have been relatively plentiful. In each the years between 2004 and 2007, inclusively, they have had roughly four official meetings at Putin's behest (while they have had only two in 2003).

So, not only was the Moscow Patriarchate's stature impressive in the early years of Putin's presidency, it has only grown in the years since Russia joined the OIC as an observer-nation. But where is the Russian Muslim community in all this?

\section{Imagining Diversity}

As was stated in the introduction to this section, there is some evidence that the Russian state does not fully reflect Russia's Muslim character, even to the point to which there is little to no mention of it with concerns to the conflict in Chechnya or to

${ }^{130}$ Кремль, Послание Федеральюму Собранию Российской Федерации (Москва: Президент России. Официальный Сайт, 25 April 2005, 26 April 2007) archive.kremlın.ru (accessed 31 July 2010). This reinforces Hunter's idea of Putın's ethnocentrism that was mentioned before. 
communications with Tatarstan. Moreover, while President Putin met with Aleksy II a total of 19 times from 2003 and 2007, he had only five similar encounters with leaders of Russia's Muslim community. ${ }^{131}$

Russian officials only started to admit they represented a minority of Muslims when they began expressing their interest in joining the OIC. Or at least, it is only then that they started doing so more openly. They spoke of their 20-million strong Muslim population when making overtures to the OIC. They held meetings in Kazan, highlighting the Tatar republic's attachment to Islam, while only years ago it had been Turkic. Last, but not least, Chechnya stopped being Muslim as soon as it started being such. In his presidential addresses to the Federal Assembly, Putin never once made a direct mention of the conflict's Islamic character, just mere allusions to its interconfessional nature.

This sense of otherness with which most of the Russian political elite seems to perceive the Muslim minority is given more resonance by the general debate surrounding Russia's decision to deepen its involvement in the OIC. Specifically, Russian officials describe this move as overcoming the stigma about the clash of civilizations, where people would want there to be conflict between Orthodox and Islamic polities. This point is made quite forcefully in Ambassador at large V.V. Popov's

\footnotetext{
131 These numbers were obtained by counting the mentions of such meetıngs, or the press releases associated with them, on the web sites of the President of the Russian Federation (kremlin ru) and of the Russian Minıstry for Foreign Affairs (mid ru) Therefore, they may not be entirely accurate, since less publicized or simply unofficial meetmgs might have taken place, but they still show a stark contrast of both ieligious formations' positioning vis-à-vis Russian officialdom.
} 
article published in Rossiyskaya Gazeta in $2007 .{ }^{132}$ The issue of whether or not this obstacle of civilizations has been overcome in Russian foreign policy is to be discussed further at the end of this chapter but, at this point, it is useful to suppose that the ambassador's words are accurate in their description of the gist of contemporary international relations. These words are momentous, because they suggest that Russia is inherently separate from the Muslim world. No allowance is made for partial belonging to the Islamic community on the basis of its religious minority. Russia, unambiguously. is not part of the Muslim world. This idea that Russia wants to keep its distance from Islamic countries is also felt when one looks at the main structure that was established for political cooperation with OIC countries. The initiative is called, in short form, "Russia - Islamic World. ${ }^{133 "}$ Again, a clear, unambiguous dichotomy is established between Russia as a state and Islamic polities.

\section{The Effects of International Socialization}

In the article presented in the introduction, Hopf contends that a state's identity (which also informs its interests and its normative behavior) is a "social product" "subject to both domestic and international influence." More to the point, he says that "[...] significant international others can effect changes in a state's identity, working within the constraints of that state's domestic identity terrain." So, for him, since the Russian

\footnotetext{
${ }^{132}$ МИД России, Статья посла по особым поручениям МИД России В.В. Попова «Между Западом и исламским миром», опубликованная в «Российской газете» 18 апреля 2007 года (Москва: Министерство иностранных дел Российской Федерации, 18 April 2007) www.mid.ru (accessed 24 January 2009).

133 МИД России, Заключительное коммюнике первой встречи Группы «Стратегическое видение: Россия - исламский мир», 27-28 марта 2006; Материалы второго заседания группы стратегического видения "Россия - исламский мир», Казань, 29-3I августа 2006 года (Москва: Министерство иностранных дел Российской Федерации, 31 March 2006 and 6 September 2006) wnw.mid.ru (accessed 24 January 2009).
} 
public does not identify as strongly with the United States as with Europe, relations with the former will not have as considerable an effect on the construction of the domestic identity as relations with the latter would. ${ }^{134}$ This corresponds to Gourevitch's assertion (presented in the first chapter) that international factors have an impact on domestic self-identification. These theories, however, point to the necessity of a certain similarity between the local and foreign identities for one to influence the other. As Brian Greenhill suggests, this does not have to be the case:

But it seems that this understanding of recognition [that it unites rather than separates] is only half the story. Just as recognition of the 'other' can be thought to affirm a sense of common identity, so too can we think of it as highlighting the key differences between 'self' and 'other' - and thereby accentuating their separateness without necessarily invoking any meaningful sense of shared identity. ${ }^{135}$

This dimension of identity, that functions according to a "negative pole," to borrow Corm's terminology, was already discussed in Chapter One. It supports the idea that Russia can, and has, indeed become more strongly identified with Orthodoxy as a result of increased socialization with a strange 'other': Islam. Even if one were to accept a stronger identification with Orthodoxy as an intrinsically desirable goal for the Russian leadership, one must also consider what the leadership's motivations would be for a deeper engagement both with its own Muslim minority and partners of the same convictions abroad. This is the object of the next two sections.

\footnotetext{
134 Ted Hopf, Op clt, 227

135 Brian Greenh11l, "Recognition and Collective Identity Formation in International Politics," European Journal of International Relations 14, no 2 (2008): 352
} 
Despite the strengthening of the Russian state's identification with Orthodoxy as a result of its deeper ties with the Islamic world, it should follow that the Muslim minority benefits in some way from this new development. Hunter contends that Putin "co-opts" Muslim minorities, thereby keeping them in control. ${ }^{136}$ While this assertion is indeed credible, a second look at the motivations of that same minority and of the state for pursuing a more active policy in the Islamic world is warranted to ascertain its accuracy. An examination of the benefits reaped by the Muslim minority since joining the OIC opens the discussion.

\section{A Prophet Comes Bearing Gifts}

By joining the OIC, Russia had to demonstrate its seriousness as a protector of its own minority's interests and provide them with new opportunities within the country. One such opportunity was the Fund for the Support of Islamic Culture, Science and Education (from now on, the Fund), first endowed in 2007 by the Russian Government. ${ }^{137}$ Former President Putin presented this fund to a group of Muslim leaders as intended to enable the development of Islamic sciences in Russia. From a strictly domestic perspective, the initiative does not look entirely promising for its intended beneficiaries, without being fallacious. ${ }^{138}$ There are still indications of a lack of

\footnotetext{
${ }^{136}$ Shireen Hunter, Op. cit., 197.

${ }^{137}$ МИД России, Статья посла по особым поручениям МИД России В.В. Попова «Между Западом и исламским миром», опубликованная в «Российской газете» 18 апреля 2007 года. «Фонд поддержки исламской культуры, науки и образования.»

${ }^{138}$ Therein lies the problem of assessing Russian domestic policy on a moral basis, as much for experts as for Russia's international partners. This particular issue will be revisited in chapter four.
} 
a serious interest from the part of the state to make this a credible program through which the multiple facets of Muslim culture can be realistically developed by Muslims, for Muslims, and that, with state support. The Fund is headed by Primakov, who is not Muslim, and one can ask whether a non-Muslim can produce the right momentum for the development of initiatives that are dependent on a sense of belonging to a specific culture for their relevance and success. Unfortunately, it proved impossible to find information about the programs funded through this channel on the website of either the Russian Federation's Ministry of Culture or the Ministry of Education and Sciences.

Another indication of the state's apparent disinterest in the Fund is the attention that was brought to it in the President's Address to the Federal Assembly in 2007, when Putin made science and technology a significant part of his speech. He outlined the budgetary priorities for science and technology (S\&T) projects in 2008, making announcements for over 200 billion rubles of financing for S\&T. In this context, he may not have wanted to announce the Fund's original endowment by the state to the amount of only 60 million rubles in a high-profile speech! Indeed, despite the fact the Fund was established in 2007, not a single mention of it can be found in the President's address about S\&T in the very same year. ${ }^{139}$ This speaks volumes about the Russian political elite's belief in the project's real chances to make a difference for the country's Islamic community. But, to achieve a full perspective on the assumed intent of the project, one must look at its international aspect as well. This will be done in the next chapter, about Russia's foreign policy towards Saudi Arabia.

\footnotetext{
139 Кремль, Послание Федеральному Собранию Российской Федерации (Москва: Президент России: Официальный Сайт, 26 April 2007) archive.kremlin.ru (accessed 31 July 2010).
} 


\section{Unread Small Print}

Joining the OIC itself turns out to be one such gift. After all, it had been a demand of Russia's Muslim leadership for some time before it happened. ${ }^{140}$ However, the Muslim leadership failed to take into consideration the concessions that would be requested from their part when Russia's new status in the OIC would materialize. These concessions are mostly political, and the most credible piece of evidence of such concessions are the transcripts of the meetings that took place between the leader of the Council of Russian Muftis Ravil Gainutdin and Putin in 2004 and 2007, both before and after Russia became an observer-nation in the OIC.

A careful study of these transcripts reveals that, in those meetings, Gainutdin took a conciliatory, almost apologetic, tone towards Putin while explaining Islam's relative position in Russia. In short, he reassures the President that Islam is a nonviolent religion full of goodwill, a posture Aleksy II never adopted when discussing Russian Orthodoxy with Putin. Moreover, Gainutdin never received the kind of warm endorsement his Orthodox counterpart was bestowed, was never thanked for his contributions to Russian political life. Instead, it was Gainutdin who thanked Putin for the latter's role in championing Russia's quest for recognition as an observer-nation of the OIC. And, at the 2007 meeting with other Muslim leaders present, Gainutdin, along with the others. could not possibly have criticized any aspect of the Fund for the Support of Islamic Culture, Sciences and Education that was presented to them by the

\footnotetext{
${ }^{140}$ Dmitry Shlapentokh, "Islam and Orthodox Russia: From Eurasianism to Islamism", Communist and PostCommunist Studies 41 (2008): 33.
} 
President, both its leadership and its limited endowment, if only for reasons of protocol. ${ }^{141}$

However, this remains problematic for the Muslim leadership, since they expressed their support of a state initiative and are mostly deprived, because of the Russian Orthodox Church's solid grip on the domestic religious debate, of a means of communication of their displeasure with any aspect of the Fund's management. In other words, they have done what Anastasia Mitrofanova thought could happen to Orthodox Churches by harmonizing their policies with the state: become too close to it to be able to criticize credibly. ${ }^{142}$ However, contrary to the Moscow Patriarchate, the Russian Muslim leadership pronounced a closeness to the state from a position of subservience and dependency, without the power necessary to exist on its own. The Russian Muslim leadership did not manage to avoid being portrayed as being satisfied by the state's defense of their interests, and in a position from which it is difficult, if not impossible, to recover.

\section{WHAT RUSSIA WANTS}

Hunter mentioned, in addition what was related earlier in this chapter, that joining the OIC should make Russia more understanding of the interests of its Muslim minority. Or, if Russia does understand those interests, it chooses to ignore them in favor of

\footnotetext{
${ }^{141}$ Кремль, Начало втречи с Председателем Совета муфтиев России Равилем Гайнутдином, Начало втречи с лидерами мусульманских организачий России (Москва: Президент России: Официальный Сайт, 26 May 2004 and 10 January 2006) archive.kremlin.ru (accessed 31 July 2010).

${ }^{142}$ Anastasia Mitrofanova, Op. cit., 173.
} 
pursuing higher priorities, such as territorial integrity. ${ }^{143}$ But, inasmuch as those interests do not directly contradict the state's territorial integrity (i.e. separatism), the Russian state has demonstrated willingness for accommodation. In turn, it used this new concessions to extract public declarations of support from the country's Muslim leaders, thereby silencing any future criticism that may arise from their part. By approving of the Russian state's concessions towards them. Muslim leaders are also implicitly acknowledging the role the Russian Orthodox Church (be it direct or not) played in obtaining those concessions in the first place.

This balance of power is satisfying for both of its main benefactors, the state and the Church. For the former, it is the restoration of its authority in the federal territories where it has been threatened with separatism, especially in Tatarstan and Chechnya. By taking formal steps to deepen its relations with Islamic states of many stripes, Russia was able to positively respond to the discontent of its restive Muslim minority through initiatives with foreign partners. For the Moscow Patriarchate, it allowed for the expansion of its social and political activism on what it sees as its canonical territory, over which it has inherently hegemonic ambitions, stemming from the organization's social and historical context, by which it finds itself inextricably bound with the state. This hegemonic desire is in line with Rancière's predictions about the rationale for inter-group conflict, as discussed in the first chapter: the suppression of minority discourses (not of their proponents).

${ }^{143}$ Shireen Hunter, Op. cit., 282. 
Joining an international organization of an overtly Islamic character could have jeopardized the Russian Orthodox Church's position of spiritual leadership in Russian society that could only have been prevented with the participation of the state. Fortunately, they have found sufficient common ground on policy to cooperate on key issues. Through this condominium, the Church was able to secure state support for its project of reunification with its foreign branches. More importantly, it also won recognition as a legitimate actor in public policy, including foreign policy. And, despite the largely symbolic nature of the concessions the Russian state made to the Muslim minority, the latter finds itself indebted to the Moscow Patriarchate. After all, the President himself made a point of personally thanking Aleksy II for his role in bringing about Russia's new status in the OIC. The former Patriarch's participation in this initiative was also highlighted by then Minister for Foreign Affairs Lavrov on the occasion of Russia's first participation at the OIC as an observer-nation. ${ }^{144}$

More than a proxy for its domestic policy, the OIC proved to be a useful outlet for the more classical forms of Russian foreign policy because these relations have provided many incentives for an avoidance of conflict, even on thorny issues. These incentives and issues will be the object of a more detailed discussion in chapters four and five. Two specific cases of bilateral relations will be studied: the Islamic Republic of Iran, but first the kingdom of Saudi Arabia.

\footnotetext{
${ }^{144}$ МИД России, Выступление Мипистра иностраппых дел России С.В.Лаврова на 32-й Конференции министров иностранных дел стран-членов ОИК, Сана, 29 июня 2005 года (Москва: Министерство иностранных дел Российской Федерации, 29 June 2005) www.mid.ru (accessed 24 January 2009).
} 
The study of those cases will shed light on a few specific matters. First, they help to determine whether Huntington was accurate in predicting conflict between Russia and the Islamic world on the sole basis of their difference in identity. As was clearly demonstrated in the past chapters, Russia can be described as an Orthodox state (following the same definition that has been set for Islamic states in the introduction). In turn, this will make it possible to draw larger conclusions about the general thrust of Russian foreign policy, more specifically, to what extent Putin has a "Soviet tendency to see the world in terms of friends and foes. ${ }^{145}$ " However, a quick survey of the research material for these case studies does not reveal such a pattern. Specific case studies of Russia's foreign policy towards Saudi Arabia and the Islamic Republic of Iran follow a short theoretical recap of what has been discussed in Chapters Two and Three.

145 Paul Anderson, Op. cit., 194. 


\section{Interlude: Manus Dei}

The observations that have been made on the Russian Orthodox Church reveal that the institution has articulated, in its own discourse, goals similar to those that have been theorized by Gramsci with regards to the objectives of religious institutions, and by Thomas Bremer in his predictions regarding contemporary Church-State relations in Russia. In practice, the Moscow Patriarchate has openly and actively, through its Social Concept, tried to define its social position in relation to the Russian state by delivering prescriptive practices for governance. Relations at the top of the Church and State hierarchies have also been cultivated over the years. The greater social interests of the Church has been recognized by both the population - which, according to media sources, is rather ambiguous about this expanded role - and by the state, which has reacted much more positively.

This has not prevented the state from discursively constructing its Muslim population as a political minority with genuine interests and claims, a phenomenon that is acknowledged by poststructuralist research as a simultaneous construction of subjects and policies: "Policy discourses construct - as do discourses in general problems, objects, and subjects, but they are also simultaneously policies to address them. ${ }^{146}$ So, in constructing a Muslim minority as such (that is to say, a minority based on religious affiliation), the Russian state also devised policies that would coincide with both its own interests, and those of the newly minted minority. Now, Derrida has argued "the conventional conditions for the success of speech acts are inexhaustibly

\footnotetext{
${ }^{146}$ Lene Hansen, Op. cit., 21.
} 
open textured, a fact that implies that the sphere of normal speech can never be clearly delineated," suggesting that it is not truly possible, with reference to the Russian state's discursive construction of a Muslim minority, to ascertain the state's intentions in doing so; was it genuinely believing in its own discourse, or was it using, so to speak, the idea of a Muslim minority for its own ends $?^{147}$ From a theoretical standpoint, this is not fully relevant to do so, since discourse analysis, by associating the discourse with the policy, "expos[es] a power phenomenon where it was claimed only reason existed. ${ }^{148 . "}$ In other words, the policy contained in the discourse is simultaneously produced and justified by that very same discourse, which had no previous basis in reality. ${ }^{149}$

Then, if Russia joined the OIC as an observer-nation, poststructuralist discourse analysis suggests, it is not because it had a Muslim minority, but rather it created a Muslim minority, where there were only adherents to Islam, in order to join the OIC. This has created a situation where the state had to respond more actively to the interests of its Muslim minority. Evidence suggests that, despite official efforts, the Muslim community has remained marginal in Russian political life; whether this is because the policies are ineffective or because the Muslim community itself is too weak relative to the Orthodox community to position itself favorably within society. It is also possible that the Russian state is not truly committed to the Muslim minority it created; finding that out, however, would require access to what James $C$. Scott calls the state's

\footnotetext{
147 Stephen K. White, Op cit, 194.

148 Ibid., 188.

149 Ibıd , 196.
} 
'hidden transcript': classified documents. ${ }^{150}$ Even were an inquiry into this possible, it is not the object of this essay to research the ethical dimensions of discourse, something poststructuralism is not fit to do..$^{151}$

Rather, the level of analysis will now be moved to the international system with two case studies, Saudi Arabia and Iran, to see how Russia discursively constructs its foreign policy towards them, if the strong Orthodox identity of Russian society proved to be incompatible with those two Islamic countries.

150 James C. Scott, Domination and the Arts of Resistance: Hidden Transcripts (New Haven: Yale University Press, 1990), 10.

${ }^{151}$ Stephen White, Op. cit., 190. "In effect, Foucault's position seems to allow no normative criteria of better or worse $[\ldots] "$ 


\section{Chapter 4: Flirtations with the Holy Kingdom}

Islam is the faith of the majority in Saudi Arabia. But, more than just a religion, Islam is an omnipresent aspect of socio-political life and this is in no small part due to the regime's own free association with it: "The brand of Islam with which the House of Su'ud has always identified itself, and has promoted internationally, carries with it a missionary militancy framed around its puritanical 'return to the foundations' ideology." ${ }^{152}$ This means the Saudi regime has an obligation to actively promote the spread of Islam abroad and defend it at home, so much so that this obligation justified Saudi support for the United States' fight against the Soviet Union in Afghanistan in the 1980s. ${ }^{153}$ The defense of Islam interest worldwide is therefore part of what Nonneman qualified as being part of the Saudi 'role conception'. ${ }^{154}$

Evidently, the Saudi government accepts the role of the promotion of Islamic interests worldwide. Based on the principles of good-neighborliness and the nonintervention in the internal affairs of other states, Saudi Arabia is organized around 'circles' of activity, of which the wider Islamic world comprises the third (the first two being the Gulf region and the Arab world). The empowerment of the Organisation of The Islamic Conference and the defense of Muslim minorities worldwide are targeted as two objectives pursued by Saudi Arabia as part of its agenda in the wider Islamic

\footnotetext{
${ }^{152}$ Tim Niblock, Saudl Arabıa Power, Legitımacy and Survlval (New York and London· Routledge, 2006), 4

${ }^{153} \mathrm{Ibld}, 69$

${ }^{154}$ Gerd Nonneman, "Determinants and Patterns of Saudı Foreign Policy: 'Omnibalancing' and 'Relative Autonomy' in Multıple Environments" in Paul Aarts and Gerd Nonneman (ed ) Saud Arabia in the Balance Polltical Economy, Socıety, Forelgn Affairs (New York· New York Unıversity Press, 2007), 339
} 
world. ${ }^{155}$ This, coupled with Saudi Arabia's engagement not to interfere in the internal affairs of other states, the obligation it has to promote - sometimes radical forms of Islam, and the risks it runs in being perceived as not doing so domestically, makes for a complicated foreign policy to formulate and execute. In this context, even satisfying its basic security needs becomes problematic, as partnerships with certain states can open up the regime to accusations of falling short of upholding Islamic values. ${ }^{156}$

Where the issue becomes much more complex is when this support for those Islamic values is done by funding organizations abroad. Apart from the obvious difficulty stemming from certain states' opposition to the foreign financing of nongovernmental organizations, including Russia, ${ }^{157}$ comes from the lack of real control the Saudi state has on the end-use of those funds. Indeed, Gerd Nonneman notes that, while there is little evidence suggesting the Saudi state supports the use of terrorist tactics to advance its Islamic agenda, it cannot reliably track the funds and ensure that its money is not used in violent endeavors. ${ }^{158}$ Since it cannot account for the use of the funds it disburses, it would be counter-intuitive for the state to cut these off completely, since it could mean severing support for peaceful Islamic organizations. And, even if the organizations in question are not peaceful, they could still be seen as appropriate

155 Saud MFA, The Foreign Policy of the Kingdom of Saudl Arabia (Riyadh: The Minıstry of Foreign Affarrs of the Kingdom of Saud1 Arabia, 2005) unw mofa gov sa (accessed on 12 August 2010).

${ }^{156}$ Tim Niblock, $O p$ cit, 69

157 Кремль, Послание Федеральному Собранию Российской Федерачии (Москва: Президент России: Официальный Сайт, 26 Aprıl 2007) archıve kremlın ru (accessed 31 July 2010). In his presidential address of 2007, former President Putın directly denounced certain religious organizations (without namıng them) for accepting money from foreign interest groups.

${ }^{158}$ Gerd Nonneman, $O p$ cit , 341-342. 
proxies by the representatives of the more radical strains of Islam on whose support the Saudi state depends for its own domestic legitimacy. ${ }^{159}$

In this regard, one could hardly see how Saudi and Russian interests converge. In fact, one could foresee the potential for conflict, since religious interests of a radical inclination that the Saudi state cannot fully control support the use of using unorthodox tactics to promote themselves in the Caucasus (and in Central Asia). Moreover, relations between the two states could be understood as relatively fragile, as they have not had diplomatic relations for most of the twentieth century. Soviet diplomatic representation to Saudi Arabia was discontinued in 1938 by the People's Commissariat for Foreign Affairs (NKID) "under the pretext of cutting down on its international operations." They were restored only in 1991, two years after the Soviet withdrawal from Afghanistan the Saudis supported, but shortly after the collapse of the USSR itself. Saudi Arabia almost immediately recognized the new Russian Federation (on 30 December 1991), and relations have not been cut off again since then. Instead, they have been punctuated by several bilateral visits by high-ranking officials, ${ }^{160}$ suggesting a constructive, if not always easy, relationship.

However, the rhythm of recent Russian-Saudi relations is not, in itself, an explanation for the failure of Huntington's and Anderson's predictions for conflict to

${ }^{159}$ F. Gregory Gause III, "The Foreign Policy of Saudi Arabia", in Raymond Hinnebush and Anoushiravan Ehteshami (eds.). The Foreign Policies of Middle East States. Boulder: Lynne Rienner Publishers Inc., 2002, 194.

${ }^{160}$ МИД России, Российско-саудовские отночения (справочная информачия) (Москва: Министерство иностранных дел Российской Федерации, 26 Мау 2008), www.mid.ru (accessed 10 March 2009). It is interesting to note that the official Russian position on the severance of relations with Saudi Arabia remains a matter of 'pretext', the real reason of which is not given to this day. 
materialize between the two parties. After all, it is not obvious to determine what brings these two countries together: the expert Western opinion is that Russia, at best, 'coopts, controls or manipulates' its Muslim minority and the interests of this minority have recently become more difficult to assert following the rapprochement between the Russian state and the Moscow Patriarchate. ${ }^{161}$

Moreover, they are at odds over the conflict in Chechnya. Russia as the federal state wanting to reassert its sovereign authority over the territory and restore order. In fact, according to Matthew Evangelista, "the reassertion of central control over the rebellious territory of Chechnya" was "the main - perhaps only - goal" of Putin's "political project" and that, for this reason, "it must rank above any considerations of international prestige." ${ }^{162}$ Saudi Arabia, on the other hand, hosts radical Islamic organizations that have declared an interest in exerting influence in the region. The Saudi state's position is precarious, since it cannot denounce these groups' actions without putting its survival, or at least its stability, on shaky grounds, therefore weakenıng its negotiating position vis-à-vis Russia. A favorable resolution of these issues is thus vital to both sides, which is why they have been chosen to make sense of Russian foreign policy towards Saudi Arabia. The conflict in Chechnya is examined in the first section, while other elements of Russian-Saudi cooperation are considered in the second. ${ }^{163}$

\footnotetext{
161 Shireen Hunter, Op cit, 383-384

162 Matthew Evangelista, The Chechen Wars Will Russia Go the Way of the Soviet Union? (Washington, D C. Brookings Institution Press, 2002), 140

${ }^{163}$ The examination of the Chechen conflict will be strictly limited to the context of Russian foreign policy towards Saudi Arabia (and to some extent, the rest of the Islamic world) without taking stock of the ethical or moral dimensions of the issue.
} 


\section{CheChNYA}

The conflict in Chechnya is probably considered to be the most significant factor influencing Russian-Saudi relations, and not for the better, at least not according to Hunter's assessment of the issue. Pointing to older developments linked with the conflict, she presents a range of actions posed by the Saudi leadership to support the idea that Russian-Saudi relations soured as a result of the conflict in Chechnya. Specifically, she affirms that Saudi Arabia "took the lead in bringing the Chechens' plight to the attention of the Muslim world," noting that the country referred the matter, along with the Bosnian war, to the attention of the United Nations Security Council for an immediate resolution. This was in December 1994-January 1995. She also points to the Saudi leadership's later denunciations (in 2000) of the Russians' conduct in the region ("inhumane acts") and their other statements in support of the Chechens' "right to self-determination," the true meaning of which she admits is open to interpretation. ${ }^{164}$

All of these statements can be understood in the wider context of Saudi Arabia's duty to uphold the interests of Muslims everywhere in the world, and even of a respect by the Saudi leadership of the norms of international law, behavior and institutions. It is indeed a logical way to interpret the referral of the Chechen conflict to the UNSC. It provided a way for Saudi Arabia to credibly fulfill its duty to Muslims, and that in the spirit of international law and non-interference in the internal affairs of other states,

\footnotetext{
${ }^{164}$ Shireen Hunter, Op. cit., 383-384.
} 
while not unduly antagonizing Russia over a proposal the latter could easily defeat as a veto-wielding permanent member of the Security Council. This also came after statements by King Fahd to Kozyrev in 1992 about Saudi support for Russian territorial integrity, which, ultimately, is the death knell of the ambitions of Chechen separatists, and an encouragement of the Russian state's goals. ${ }^{165}$ Whether or not these statements by Saudi Arabia's leadership correspond or not to the reality on the ground in Chechnya does not impinge on the possible diplomatic backlash that could have resulted by these accusations. After all, Russian officialdom could not possibly have tolerated a point of view that condemned its actions on its sovereign territory. Little evidence supports the thesis that Russian-Saudi relations soured after these multiple condemnations by the Saudi leadership, especially not in the context of the restoration of diplomatic ties that was relatively recent at the time of those interventions from the Saudi side.

Actually, there exists evidence to the contrary. Since 2000, Russian-Saudi relations have expanded both within and without the context of the OIC. Indeed, Saudi Arabia supported Russia's entry into the Islamic Conference, even while it would likely have been possible for it to exert what experts call its considerable influence over the OIC's activities to prevent such a development. ${ }^{160}$ Its prior denunciations of Russian actions in Chechnya would have provided an excellent justification for such a refusal, and might even have further enhanced its stature in the Islamic world. Instead, Saudi Arabia not only acquiesced to Russia's new status as an observer-nation in the OIC, but did not oppose the organization's role as an election monitor in Chechnya's elections of

\footnotetext{
${ }^{165}$ Id.

${ }^{166}$ F. Gregory Gause III, Op. cit., 198. The creation of the OIC is a Saudi initiative dating to 1969.
} 
2005 at Russia's request ${ }^{167}$ Even if OIC states have a spotty democratic record at best, the election's legitımacy would nevertheless be buttressed by the approval of states of the international Islamic community rendering hard if not impossible, for Chechens or other Russian Muslıms to describe the event as being tinged with imperialism This not only strengthens Russia's hand in reasserting its authority in the breakaway republic, but also serves as an endorsement of the elections as, at least, a gesture of political goodwill from Russia's leadership The Russian politıcal elite therefore makes itself more difficult to criticize by those same Islamic states, in turn, those Islamic states can credibly present their role in the elections as furthering the interests of a Muslim minority since a successful election would mean a scalıng back of federal military activity in the republic The security of Chechnya's Muslim population is therefore enhanced, and everyone who participated in the solution can tell their constituencies about the role they played in reaching it

Of course, there remains the thorny issue of financing for radical Islamists operatıng in Chechnya, some of which are Wahhabis originatıng from the Arabian peninsula that is also sure to be the source of part of those funds This particular issue was raised, albeit without pointing fingers by President Putın in his Address to the Federal Assembly of 2007 He noted the "pernicious role of foreign financing" intended for "internal interference" in "stoking inter-confessional conflict "168 It is possible that Putın was alluding to financing coming from Saudı Arabia After all he had visited the

\footnotetext{
${ }^{167}$ МИД России, Выступление Министра иностранных дел России С В Лаврова на 32-й Конференұии министров иностранных дел стран-членов ОНК Сана 29 июня 2005 года (Москва Министерство иностранных дел Российской Федерации, 29 June 2005) w w mid wu (accessed 24 January 2009)

${ }^{168}$ Кремль, Послание Федеральному Собранию Российской Федерации (Москва Президент России Официальный Сайт, 26 April 2007) archıve kremlın ru (accessed 31 July 2010)
} 
country only three months earlier, on which occasion he met with Saudi politicians as well as members of the country's business elite. ${ }^{169}$ This visit was but the latest in a long series of visits by high-ranking Russian and Saudi high-ranking officials and ministers, including visits by both countries' Foreign Affairs ministers, and visits by Tatarstan's president Shaimiev and Chechen president Kadyrov who, during his holy pilgrimage in 2006-2007, met with the Saudi king. ${ }^{170}$ Moreover, in his address to the $39^{\text {th }}$ Munich Conference on Security Policy in 2003, Defense Minister Sergey Ivanov lengthily discussed the issue of Chechnya. In his speech, he mentioned a number of countries from which Russia believed the fighters in Chechnya were originating. He doing so, he singled out Turkey, Azerbaijan, and even the United States and Japan, but made no more than a passing mention of "a certain number of Arab countries" as the source of the fighters. And that is despite the fact that he had previously mentioned "Saudi Wahhabism" as one of the problematic ideologies inciting violence in the autonomous republic (he did mention Saudi Arabia's role in releasing entry visas to some of the rebels). ${ }^{171}$ However, there is little evidence, from Russia's actions and continuing contacts with Saudi Arabia, of a serious chill in the relationship because of the latter's perceived role in the Chechen insurgency.

\footnotetext{
169 Кремль, Вытупление на втрече с председателями деловых кругов Саудовской Аравии (Эр-Рияд: Президент России: Официальный сайт, 12 February 2007) archive.kremlin.ru (accessed 31 July 2010).

${ }_{170}$ МИД России, Российско-саудовские отноиения (справочная информачия) (Москва: Министерство иностранных дел Российской Федерации, 26 Мау 2008), www.mid.ru (accessed 10 March 2009).

${ }^{171}$ Sergey Ivanov, "Speech at the 39th Munich Conference on Security Policy", $39^{\text {th }}$ Munich Conference on Security Policy (2008) www. sccurityconference. de (accessed on 23 January 2009).
} 
A number of agreements on science and technology were reached during Putin's visit of 2007, and some were focused on cultural issues. This problematic is discussed in the section.

\section{A MiNORITY STAKE IN RUSSIA}

Common endeavors in science and technology and other commercial fields of interest were nothing new in Russian-Saudi relations. In October 2002, two years after Saudi Arabia's scathing attacks on the nature of Russian military activity in Chechnya, the first session of the Combined Russian-Saudi Commission on Commercial Trade, Scientific, Technological and Cultural Cooperation, took place in Moscow with the participation of the Russian Minister of Energy and the Saudi Minister of Finance and Economy. At the time of this first session, it was agreed to establish firmer bases for further cooperation, including in the field of cultural contacts. ${ }^{172}$

This was at least partly realized in 2007 on the sidelines of Putin's official visit to Riyadh. A Memorandum and Program of Cooperation for 2007-2009 was signed by the Ministry of Culture and Information of the Kingdom of Saudi Arabia and the Russian Federal Agency for Culture and Cinematography. ${ }^{173}$ Unfortunately, the document itself was not possible to obtain. ${ }^{174}$ Still, it coincides closely in time with the endowment of the Russian government's Fund for the Support of Islamic Culture. Science, and

\footnotetext{
172 МИД России, Российско-саудовские отношения (справочная информачия) (Москва: Министерство иностранных дел Российской Федерации, 26 May 2008), www.mid.nu (accessed 10 March 2009).

${ }_{173}^{17}$ Id.

${ }^{174}$ At the time of this writing, it was not available on the websites of the Russian Government, and the English-language version of the Saudi Ministry of Culture and Information's website was still under construction; Arabic was the only other language available.
} 
Education, and could possibly inscribe itself as a complementary dimension to the Fund. It is otherwise evident that the Fund was a common initiative between Russia and other Islamic states (likely Saudi Arabia) in the context of the strategic partnership Russia - Islamic World. ${ }^{175}$

Primakov's nomination to head the Fund further supports the idea that it might be a tool for Russia to enhance its legitimacy and prestige with its domestic and international Islamic interlocutors. This was first pointed out because the Fund, not being led by a Muslim, cannot fully take into perspective the full spectrum of Islamic arts and sciences. But, more than this, Primakov's own background supports the thesis of the Fund as a bargaining chip. At different points since the formation of the postSoviet Russian Federation he served in multiple political posts, including that of prime minister and foreign affairs minister. He himself has an extensive diplomatic pedigree. He is also known as a proponent of the Eurasianist school of thought, which purports that Russia, as a multi-confessional country, constitutes a hybrid nation of Eastern Christian and Muslim followers that follows its own geopolitical way, straddling Europe and Central Asia. As such, his background as a proponent of this ideology makes him an ideal candidate for a post where he might be asked to represent the interests of the Muslim minority on behalf of the Orthodox Russian state.

175 Ibid. 
Meanwhile, commerce between Moscow and Riyadh soared. From 2000, when Saudi Arabia denounced Russia's "inhumane acts" in Chechnya, to 2007, bilateral economic exchanges had grown by six times. ${ }^{176}$ This does not hint at a bad relationship.

\section{Protector of THe Muslim Community}

The evidence presented in this chapter points in one direction. It strongly suggests that the Russian political elite has demonstrated a certain measure of knowledge of Saudi Arabia's vested interest in presenting itself as a defender of Islamic welfare worldwide. Based on this knowledge, it has shown a willingness to keep engaging with Saudi Arabia despite vocal denunciations of Russian actions on its sovereign territory. This engagement was made with an overt cultural and religious bias in order to meet both the needs of Saudi Arabia and accomplish domestic Russian goals as well: calming the unrest in Chechnya and establishing a better basis for the integration of Muslims in Russian society (notwithstanding the perceived weakness of that basis). A successful and sustained implementation of this policy of constructive engagement with influential Islamic polities such as Saudi Arabia could mean the establishment of an order where the Russian Federation's territorial integrity is no longer threatened from the inside, and in which Russian citizens can live free of the fear of terrorist attacks committed by radical separatists.

Other scholars writing on the particular issue of Chechnya asserted there was a dichotomy between its "concern for territorial integrity" and its "international prestige,"

\footnotetext{
${ }^{176}$ Ibid.
} 
whereas such a dichotomy cannot be ascertained. ${ }^{177}$ Russia ably used bargaining on the international stage to gain access to a forum where it could find common ground with member-states, one in particular, to craft initiatives furthering mutual interests devised to positively affect its domestic policy outcomes. It did so despite expectations in expert and scholarly circles that the differences in religious identity would be an intrinsic obstacle to the development of cooperative relations and pose additional security dilemmas. Instead, it conducted a responsible foreign policy with a state that identifies with a radical strain of activist Islam, and is even a traditional partner of the United States, Russia's erstwhile arch-enemy.

A second case study should provide additional information regarding the general thrust of Russian foreign policy in the Islamic world.

${ }^{177}$ Shireen Hunter, $O p \quad c t t$, 383-384. Matthew Evangelısta, $O p \quad c t t, 140$. 


\section{Chapter 5: The Conundrum of the Islamic Republic}

Iran's Islamic pedigree is hard not to recognize, starting with the country's official name. And it is more than just a name. It was established after the 1979 revolution, in which Ayatollah Khomeini overthrew the American-friendly regime of the Shah and, in its stead, installed a theocratic republic. This republic does not fashion itself a representative of Islam, like the Saudi monarchy does; rather, the clergy simply governs the state, even if indirectly. The clergy, from the onset of the new republic, has the power to vet candidates and reject those that they deem as not having a sufficient Islamic background. All branches of government are shadowed by clerical equivalents, including the office of president, whose powers are offset by the Supreme Leader. "This position," according to Robin Wright's study, "was created to check secular influences in all branches of government and to keep the revolution on an Islamic course." The Council of Guardians acts a chamber of decidedly sober Islamic second thought; it has an effective veto over any law passed by Parliament. ${ }^{178}$ A number of politicians. intellectuals, and a significant portion of civil society have vocally criticized this system, but it has so far survived in this form since the revolution. The debate, regardless of whether it is conducted by critics or proponents of the system, has fundamentally been centered on which aspects, to which extent, and according to which interpretation, Islam should or should not have in society. The first high profile politician to have done so is former Speaker of Parliament, and then President, Akbar Hashemi Rafsanjani, who empowered the presidential office through constitutional amendments before being

\footnotetext{
${ }^{178}$ Robin Wright, The Last Great Revolution - Turmoll and Transformation in Iran (New York : Alfred A. Knopf, 2000), 14-16.
} 
elected to it in 1989 . While his program of reforms was tentative and was implemented progressively, his successor in the presidential office in 1997. Mohammed Khatami, wanted to accelerate the breadth and depth of reforms, and their pace. ${ }^{179}$ However, this reformist attempt came to a halt, or at least a pause, when Mahmoud Ahmadinejad, conservative, took over at the end of Khatami's second term.

These revolutionary forces influenced foreign policy. Experts on the matter of Iranian external activities seem to agree on a few basic principles, categorizing them according to geopolitical areas of interest. In the areas geographically closest to the Islamic Republic, they note that this policy expresses itself in decidedly religious undertones. However, this tendency tends to fade the farther the region of interest becomes. Russia falls in the latter category. Some experts attribute this to Iran's pragmatic recognition that its national interests are not served by Islamic militancy in Russia's periphery. ${ }^{180}$ Indeed, religious discourse is conspicuous in Russian-Iranian relations for its low profile, apart from one exception when Russia asked Iran to intervene on its behalf at the OIC with regards to the moderation of the organization's reaction to Russian policy in Chechnya. ${ }^{181}$ Also, Russia reciprocated Iran's support for its admission to the OIC as an observer by allowing it to take part in the meetings of the Shanghai Cooperation Organization (SCO) in a similar fashion. ${ }^{182}$ Apart with regards to

\footnotetext{
179 Ibid., 21-31.

${ }^{180}$ Ray Takeyh, Hidden Iran: Power and Paradox in the Islamic Republic (New York: Times Books/Henry Holt and Company, 2007), 60; Anoushiravan Ehteshami, "The Foreign Policy of Iran", in Raymond Hinnebush and Anoushiravan Ehteshami (eds.), The Foreign Policies of Middle East States (Boulder: Lynne Rienner Publishers Inc., 2002), 288, 303; Shireen Hunter, Op. cit., 371.

181 Shireen Hunter, Op. cit., 371.

182 Кремль, Начало встречи с Президентом Ирана Махмудом Ахмадинежсадом (Шанхай: Президент России: Официальный сайт, 15 June 2006) archive.kremlin.ru (accessed 31 July 2010).
} 
these very specific issues, religious questions do not seem to have been raised by either side in their bilateral relationship. And the issues are many, ranging from cooperation in reaching a solution to the Tajik civil war in the 1990s, the control of the traffic in narcotics in Afghanistan, the delimitation of the Caspian Sea, and conventional weapons sales, amongst others. What does this situation say about Russia's foreign policy towards Iran in particular, and towards the Islamic world in general, especially with regards to identity and religious discourse? And what is the issue, or issues, whose analysis can best determine what this trend is?

Obviously, the answer to the second question would be the flagship issue in Russian-Iranian relations, that is to say, Atomstroyexport's contract to build a civilian nuclear facility in the area close to the Iranian city of Bushehr. This issue has been the object of three United Nations Security Council (UNSC) resolutions in 2006 and $2007 . .^{183}$ Its very nature means the automatic involvement of the International Atomic Energy Agency (IAEA), as well as extensive questioning on the international non-proliferation regime, since the Western world has been preoccupied that Iran intends to use this nuclear facility as a stepping stone in research aimed at producing a nuclear warhead. The implications of this issue's resolution are global. The current study, because of its

\footnotetext{
183 МИД России, Комментарий Департамента информации и печати МИД России в связи с вопросами агентств "ИТАР-ТАСС" и "Интерфакс" относительно заявления иранской стороны о том, чтоо "резолюиия СБ ООН по Ирану не имеет под собой правовых оснований."; Заявление министров иностранных дел Китая, Франұии, Германии, Соединенного Королевства Великобритании и Северной Ирландии и Соединенных Штатов Америки при поддержке Высокого Представителя Европейского Союза в связи с принятием резолючии Совета Безопасности ООН; Интервью директора Второго департамента Азии МИД России А.Г. Марьясова службе внешнеполитической uнформачии ИТАР-ТАСС 5 апреля 2007 года (Москва: Министерство иностранных дел Российской федерации, 8 March 2006; 25 March 2007; 6 April 2007) www.mid.ru (accessed 18 August 2010).
} 
limited scope, cannot review the normative or ethical dimensions of the issue, and will instead concentrate on its geopolitical perspectives.

\section{MULLING OVER ATOMIC ENERGY}

It is useful to divide the issue's analysis in three distinct themes in order to more clearly determine what Russia's motive could be for going forward with this contentious project. Only after considering the problematic's variables under these three headings will it be possible to draw reliable conclusions as to why Russia did not let religious discourse intrude on the search for a compromise, even if to support their point of view. The first part of the argumentation concerns the constant delays that have plagued the project in the course of the previous decade, from 2001 to 2008.

\section{Signs of Anxiety}

Indeed, delays have been the hallmark of the Bushehr's plant construction, and that since the very beginning of the project in the 1970s. At that time, Germany held the contract, but dropped it at the onset of the revolution. The Iran-Iraq war delayed the search for a new partner, which Iran found in the Soviet Union in the mid-1980s. In 2001, the project was still stalled due to concerns about Iranian intentions with regards to the use of the technology provided by the Russians through the project. Specifically, the international community, at the forefront of which stood the United States and the EU-3 (the United Kingdom, France and Germany), were preoccupied about the possible developments of nuclear weapons by a country they saw as inherently hostile to Israel. China and the Russian Federation itself, as other veto-wielding members of the United 
Nations Security Council, joined forces with the Western countries to ensure Iran was complying with regulations of the Non-Proliferation Treaty (NPT) on the use of nuclear technology. This was linked to Iran's program of uranium enrichment; indeed, it possessed facilities that were producing weapons-grade plutonium that has no proven use in a civilian project. Contradictions as to the Russian reaction to these speculations by the international community can be observed in Russian officialdom's recent positioning on the matter.

This story begins in 2001, when American President Bush met President Putin at an international conference in Ljubljana. The issue of Iran's possible acquisition of nuclear weaponry was discussed between the two leaders. In a subsequent statement, President Bush reiterated his concerns about proliferation, and opined that Putin felt the same way about this; Putin later confirmed this with a statement of his own. ${ }^{184}$

Five years later, discussion about the Iranian program heated up, and was the object of debates at the UNSC, and of multiple declarations by the Group of Six (the five permanent members of the Security Council plus Germany); a resolution on the matter was even adopted. This institutional aspect of the problematic will be further analyzed in the second part of this section. It is, however, important to consider the traction the issue had gained in international circles. That year, in 2006, the President of the Russian Federation made his first state visit to the Islamic Republic of Iran. During this visit, he was interviewed by the Islamic Republic News Agency (IRNA). Many aspects of RussianIranian relations were discussed, and Putin answered a query of the journalist on the

\footnotetext{
184 John Parker, Op. cit., 109
} 
matter of the electric facility's construction at Bushehr. Lamenting the delays suffered by the project, the journalist wanted assurances from Putin that he, the Russian president, would make every effort in the remainder of his time in office towards the power plant's completion. Putin refused to give such assurances. but rather went on to explain why the project has progressed slowly. Amongst others, he cited the absence of a contractor in the years after Germany abandoned the project. He made a mention of multiple technical difficulties related to the necessity to clear away and upgrade the obsolete material that was left at the projected plant's construction site; this obsolete material being there as a result of the very long time frame in which the project has existed. He reminded the Iranian journalist that Russia is not alone in the project, and has to wait for other foreign suppliers to fulfill their part of the contract. Moreover, he cited legal difficulties in upgrading the contract to better reflect current international standards with regards to contractual agreements. ${ }^{185}$

Similar and sometimes contradictory statements have been made at the ministerial and bureaucratic levels. It shows a certain evolution in the Russian policy with regards to the plant at Bushehr. On 29 June 2005, in an interview with an Arablanguage newspaper, Minister of Foreign Affairs Sergey Lavrov stressed the contractual nature of the Iranian program. He said that the power plant's construction would continue despite the steps taken by the IAEA to ensure Iran had stopped its uranium

\footnotetext{
185 Кремль, Интервью Иранскому гостелерадио и информационному агенству ИРНА (Тегеран:
} Президент России: Официальный Сайт, 16 October 2007) archive.kremlin.ru (accessed 31 July 2010). 
enrichment program. ${ }^{186}$ In October 2007, official Ministry of Foreign Affairs spokesman M.L. Kamynina made a statement, in response to queries from the Russian media, suggesting that the state was concerned about the Iranian enrichment program. In May 2007, he had already made a statement to the effect that, according to new reports from IAEA director Mohammed El-Baradei. Iran had not taken the necessary steps to comply with UNSC resolutions that had been adopted in 2006 and 2007. ${ }^{187}$

The project ultimately went forward and, in August 2010. Russia stressed the long-term aspects of the project. Despite announcing that the start-up of the nuclear facility's first reactor would go ahead as planned, the Russian side, according to the journalist, emphasized that the process would take several months to complete. ${ }^{188}$

\section{An Institutional Approach}

While Russia stressed the long-term aspect of the project at the same time as it supported most major procedural actions that was proposed at the United Nations Security Council, therefore delaying the project through international institutions. That is, even if they could have used their veto power to prevent the adoption of measures that proved difficult for Iran to accept and comply with. Such a course of action would

${ }^{186}$ МИД России, Интервью Министра Иностранных дел России С В. Лаврова, опубликованное в арабском журнале “Аль-Ватан Аль-Араби" (Москва: Министерство иностранных дел Российской Федерации, 29 June 2005) www. mid.ru (accessed 24 January 2009).

187 МИД России, Ответ офищиального представителя МИД России МЛКамынина на вопрос российских информачионных агентств о докладе Генерального директора МАГАТЭ М Эль-Барадея по иранской ядерной программе; Ответ офичиального представителя МИД России МЛ Камынина на вопрос СМИ в связи с заявлением Президента Ирана о начале производства в Иране ядерного топлива в промышленных масштабах (Москва: Министерство иностранных дел Российской Федерации, 24 May 2007; 4 October 2007) a ww mid iu (accessed 18 August 2010).

188 Andrew E. Kramer, "Russia Sets Date for Crucial Step in Iranıan Nuclear Start-Up", The New York Times (13 August 2010) ww.nytmes com (accessed 13 August 2010). 
have had its caveats. Russian officials knew there was a possibility of military action on the part of the United States if it was not satisfied with the measures taken to ensure that Iran had resumed its moratorium on uranium enrichment, and was therefore developing its alleged nuclear weapons program. Part of the American Fleet was already stationed in the Persian Gulf, according to what the American government said was part of a planned redeployment. Supporting UNSC resolutions provided Russia with a way to stall a possible American invasion by bringing the United States to the negotiation table.

What is significant about this is that Russia always stayed on message about preferring a diplomatic solution in keeping with international law on this issue. Several significant announcements made by high-ranking Russian officials and ministers reiterate on this cornerstone of Russian foreign policy: that international problems should be settled in international forums, preferably at the UN. ${ }^{189}$ By siding with the United States and the other permanent members of the Security Council, Russia ensured that this would be the forum that would primarily be used for conflict resolution in this particular matter. It might also have prevented the occupation of Iran by the United States, which would have meant the presence of American soldiers on the southern shores of the Caspian Sea, close to Russia's borders.

At the same time, it also meant the project took more time to complete than was probably anticipated at its outset. This led to a situation where the Kremlin stated that

\footnotetext{
189 This can be found in multiple declarations and official documents of the Russian Federation, as well as speeches by senior ministers and the President, including: Vladimir Putin, "Speech at the $43^{\text {rd }}$ Munich Conference on Security Policy", $43^{\text {rd }}$ Munich Conference on Security Policy (2007) www.scourityconforence. de (accessed 1 April 2008).
} 
the \$1-billion project "was no longer profitable", seemingly as a way to downplay the importance of the recent developments. ${ }^{190}$ This apparent lack of concern for profitability is somewhat strange when one considers that, for Russia, according to some experts on Russian-Iranian relations, the project had a strictly commercial nature. ${ }^{191}$

However, to more accurately determine what this might mean, one needs to consider Iran's more general position within Russia's foreign policy concept.

\section{AWKWARD NEIGHBORS}

In the Russian Federation's Foreign Policy Concept of 2000, Iran was described as a country with which it was "important" to develop relations. ${ }^{192}$ Only this one line was dedicated to a country in which Russia was committed to build a nuclear energy plant, and had a disagreement about the delimitation of the Caspian Sea dating back to the Soviet Union's collapse.

Indeed, up until the independence of the Soviet republics, the Caspian Sea had been shared in equal shares by the USSR and Iran, which were its only two littoral states. When the dust settled, five republics found themselves having to work out a new formula to share the sea, which, it was discovered, was a relatively rich source of offshore oil and gas. According to U.S. Department of Energy estimates, these reserves

${ }^{190}$ Andrew E. Kramer, "Russia Sets Date for Crucial Step in Iranian Nuclear Start-Up", The New York Times (13 August 2010) www.nutimes.com (accessed 13 August 2010).

191 John Parker, Op. cit., 104.

192 Igor S. Ivanov, The New Russian Diplomacy (Washington, D.C.: Brookings Institution Press, 2002), Annex. 
would amount to between 17 and 33 billion barrels of proven oil reserves (and up to 200 billion barrels of possible reserves), and as much as 232 trillion cubic feet of natural gas; this amounts to roughly five percent of proven world reserves for each resource. ${ }^{193}$

Two formulae predominate in order to share the sea. One is coastal sovereignty, which would divide the sea into parts proportional to the length of each state's coastline; this is the option favored by Russia (as well as Kazakhstan and Azerbaijan). Iran, however, would lose out if the sea were divided in such a way, and so prefers delimitation into five equal shares. ${ }^{194} \mathrm{~A}$ legal solution to the problem still has not been reached between the parties. According to some experts, it would even be in Russia's interest to keep the conflict from being resolved, since it would keep the other littoral states' energy transit systems in a state of legal limbo. This would leave Kazakhstan and Azerbaijan (and Iran) partly dependent on Russian support for energy export routes. Russia therefore affirms itself as the region's superpower, a position it can afford since, reportedly, the energy reserves in its own part would be limited. ${ }^{195}$

This makes for a situation where Shireen Hunter's assessment of Russian-Iranian relations sounds very much accurate: that, despite having mutually beneficial relations in general, these relations are lopsided to Russia's advantage and that, when Russia saw

${ }^{193}$ Matthew Riemer, "Caspian Region Likely to Remain Critical for Foreseeable Future", Power and Interest News Report (12 January 2002) www.pinr.com (accessed 22 January 2009); Marcel de Haas, "Current Geostrategy in the South Caucasus", Power and Interest News Report (15 December 2006) www.pinr.con (accessed 22 January 2009).

194 Benedetta Berti, "Iran Strengthens its Role in the Caspian Sea and Central Asia Regions", Power and Interest News Report (6 November 2007) www.pinr.com (accessed 22 January 2009); Mustafa Aydin, "Oil, Pipelines and Security: The Geopolitics of the Caspian Region" in Moshe Gammer (ed.), The Caspian Region: A re-emerging region (London and New York: Routledge), 12.

195 Ibid., 7-15. 
benefits in the abandonment of Iran, it has done so. It does not necessarily follow, however, that Russia does not see a place for Iran in the promotion of a multipolar world. ${ }^{196}$ In making that assertion. Shireen Hunter seemed to assume a positive: Iran's position in the world order can be enhanced by Russian support, and therefore become one of its allies in countering Western influence. But, in light of her assertion that Russia has been known to forego its claim to partnership to Iran, an occurance that is observable in the previous analysis of the Bushehr project, a negative could be an interesting hypothesis. Russia, in this endeavor, made a point of empowering international organizations it has traditionally supported as the main forum for crisis resolution. In doing so, it has also been reluctant to offer Iran any guarantees about its intention of completing the project, except for general statements about its contractual obligations. Instead, it has brought up a multiplicity of caveats to justify delays in the project's completion, possibly as a loophole for pulling out of the contract if it became expedient to do so. They have already stated that the project is no longer profitable for them.

And why would Russia want to empower Iran, since it is demonstably uneasy about a possible challenger or simply counterweight to its presently favorable position in the Caspian Sea region? A quick review of official Russian meeting transcripts between Russian and Iranian officials reveals that relations between Moscow and Teheran have been, on occasion, described by negatives. In February 2005, President Putin met with the Chairman of the Iranian Council of National Security, Rohani, and Putin described relations as being "not bad on practically all levels," to which Rohani

\footnotetext{
${ }^{196}$ Shireen Hunter, Op. cit., 300-301.
} 
responded being happy at having a chance for an "exchange of opinions. ${ }^{197 " ~ I n ~} 2006$, Putin and Iranian President Mahmoud Ahmadinejad met on the sidelines of a meeting of the Shanghai Cooperation Organisation, on which occasion Mr. Ahmadinejad opined that "Russia and Iran are not opponents." 198 During the same meeting, Putin mentioned Russia's ascent for Iran's new status as an observer-nation in the SCO, which he presented as a repartie for Iran's support for Russia to receive the same status in the OIC. ${ }^{199}$ However, Iran's intention was to become a full member in the SCO, an organization mainly committed to counter-terrorism and anti-drug operations that has no geographical or identity basis for membership. Russia's partial rebuffal of Iranian desires for SCO membership should be understood in the context of plans announced by Putin to build an oil pipeline through the territory of three S.C.O. observers, including Iran, as part of his 'Energy Club' initiative. ${ }^{200}$ Iran was still denied a full participant status, despite its past activity in fighting narcotrafficking in Afghanistan, something Putin thanked Ahmadinejad for at that very same meeting in Shanghai, ${ }^{201}$ That, with the dearth of information there is readily available about Russia's official position towards Iran, except for a single line in the Foreign Policy Concept of 2000. suggests Russia's reluctance to fully engage the Islamic Republic.

197 Кремль, Начало встречи с секретарем Высиего совета начиональной безопасности Ирана Хасаном Роухани (Москва: Президент России: Официальный Сайт, 18 February 2005) archive.kremlin.ru (accessed 31 July 2010).

${ }_{198}$ Кремль, Начало встречи с Президентом Нрана Махмудом Ахмадинежадом (Шанхай: Президент России: Официальный сайт, 15 June 2006) archive.kremlin.ru (accessed 31 July 2010).

199 Id.

${ }^{200}$ Sergey Ivanov, "Speech at the 39th Munich Conference on Security Policy", $39^{\text {th }}$ Munich Conference on Security Policy (2008) www. socurityconference.de (accessed on 23 January 2009).

201 Кремль, Начало встречи с Президентом Ирана Махмудом Ахмадинежадом (Шанхай: Президент России: Официальный сайт, 15 June 2006) archive.kremlin.ru (accessed 31 July 2010). 
The role Iran could play for the achievement of a multipolar world could therefore be a negative. This could be using international organizations in concert with the Western world to bring about a compromise that all could be satisfied with. It could also be to make a point of completing the project over the United States' objections, in order to make them realize they cannot solve key international problems in a unilateral fashion. But, while doing this, projecting signals, formal (support for UN resolutions) or informal (expressed caveats, statements about the lack of profitability), as to their readiness to review their position on the project against political concessions that it might be offered.

Notwithstanding Russia's real intentions regarding its relationship with Iran, there does not seem to be a clear-cut domestic dimension to its policy towards Teheran, like there is with Saudi Arabia. Instead, the relationship seems to correspond to geopolitical, rather than internal, goals and ambitions of the Russian state. And, there does not seem to be an overt cultural or religious narrative associated with the pursuit of these geopolitical goals by Russia. This is what makes the case of Russian-Iranian relations so pertinent to the current study, in a way that is discussed in the following section.

\section{SPIRITUAL SCRUPLES?}

Indeed, there is an absence of identity and religious discourse informing specific actions in Russia's foreign policy towards Iran. This contrasts with the tenor of Russia's relations with Saudi Arabia, which are more heavily influenced by factors of religious 
identity. The most significant observable difference between those dyadic relationships are the motives, the nature of the objectives pursued by Russia. There seems to be a principally domestic preoccupation to Russia's relations with Saudi Arabia. In other words, Russia pursues a foreign policy towards Saudi Arabia that is a direct extension of domestic concerns, in this particular case, the accommodation of its Muslim minorities. With regards to its relationship to Iran, the goals pursued by Russia are more of a geopolitical nature, inscribing themselves more clearly in the paradigm of international politics. The distinction between high politics (matters related to security) and low politics (mostly social matters) is not necessarily relevant in this scenario, because Russia sees the issue of the Muslim minorities through the lens of classical security: the preservation of territorial integrity. It is true, though, that the pursuit of this goal in the case of its relationship with Saudi Arabia is done by achieving breakthroughs in social matters that take place mostly in internal public policy, and not in international relations per se.

The distinction is important, because an instrumentalization of religion on issues specifically related to international relations, such as those with Iran, could negatively affect the Russian state's bargaining position on the domestic level while reacting to international crises. Identifying its foreign policy to either Islam or even to Orthodoxy would limit the range of options available to pursue its perceived interests. To better illustrate this point, one would need to consider, however briefly, an example of Russian international relations with one of its Eastern Christian neighbors, Georgia. This can best be illustrated by an overview of the example of the war against Georgia in August 2008. 
This war flared up in the late summer of 2008 after nearly a decade of deteriorating relations between Russia and Georgia. The deterioration began when Georgia tried to distance itself from what it perceived as Russia's sphere of influence in 2002 under Shevardnadze, then accelerated after Mikhail Saakashvili became president in 2004. Always at the center of the conflict between Moscow and Tbilisi was the question of the breakaway republics of Abkhazia and South Ossetia, which had gained autonomy after armed conflicts in the 1990s. The separatist republics had been supported by the Russian Federation. ${ }^{202}$ In 2008, President Saakashvili tried to reassert Georgian authority over South Ossetia by military force, what Russian President Dmitry Medvedev called a "barbaric aggression against Russian peacekeepers" in his first Address to the Federal Assembly in November 2008. ${ }^{203}$ He went on to assert that Russia acted on a spiritual basis when it went to the defense of a small nation in the Caucasus, which is how the issue was framed, in mostly general terms. The language resembled that used in the Social Concept of the Russian Orthodox Church, even if it is not directly linked to it. Indeed, identifying Russia's foreign policy too closely and overtly with either Orthodoxy or Islam could jeopardize its multi-vectorial nature, and maybe even undermine the Russian state in the domestic bargaining that seems to be such a significant part of foreign policy formulation.

202 Ted Hopf, Op. cit.; Molly Corso, "Georgian-Russian Relations Continue to Deteriorate", Power and Interest News Report (7 December 2005) wuw.pinr.com (accessed 22 January 2009); Federico Bordonaro, "Georgia-Russia Missile Row Calls for the West to Revise its Strategy in Eurasia," Power and Interest News Report (22 August 2007) www.pinr.com (accessed 22 January 2009).

203 Кремль, Послание Федеральному Собранию Российской Федерации (Москва: Президент России: Официальный Сайт, 5 November 2008) news.kremlin.ru (accessed 21 August 2010). 
The findings of this study will now be considered in the wider context of the hypotheses that were established earlier and will be discussed in the next chapter. 


\section{Conclusion: Speaking the Language of Islam}

Due to the multitude of issues examined in this study, and their complexity, it is warranted to take a step back to consider them from the perspective of the hypotheses posited in the introduction. The point is not to validate or invalidate them, as it is rarely possible to really do so in political science research, but rather to take full stock of the nuances of the findings. This should make it possible to avoid ethical judgments that often confuse conclusions and to maintain objectivity.

$\mathrm{TP}_{1}$ : Cooperation between the Church and the state in foreign policy matters was abetted and even fostered by the Russian political elite, even President Putin during his term in office.

The study has demonstrated there existed an extensive cooperation between the Church and the state on a broad range of issues. These issues, at times, have included foreign policy matters, and there are suggestions that former Patriarch Aleksy II, as a representative of the Church, has personally participated in activities meant to further Russian interests with foreign partners. However, it has not been possible to ascertain with accuracy what issues the Patriarch discusses with his foreign interlocutors, some of whom are sometimes the same that are visited by the President.

It was otherwise demonstrated that, in some circumstances, the interests of the Church and state have proven to be coterminous, making them partners in the pursuit of domestic policies through international means. This partnership is forged through and implicit recognition of mutual interests along the lines described by Sherkat and Ellison in the branch of social movement theory relating to religious competition in civil society. This would suggest, as Haynes, Rancière, and Gramsci posited (in theoretical 
terms), that the Church, as a resurgent actor in Russian political life, would seek a dominant role within that system. Evidence of such a desire can be found in the Social Concept of the Russian Orthodox Church, by which the Patriarchate defines the role it is playing and wants to play within society, and how it wants to be positioned in relation to the state apparatus. These predictions were found to be accurate; this what would incite the Church to cooperate with the state on foreign policy matters.

This cooperation, rather than constituting a fully parallel diplomacy, has mostly taken the form of reciprocal concessions. Therefore, in exchange for domestic support on international matters that could be considered to be implicitly inimical to its interests, the Church has sought to have its political legitimacy bolstered and formally recognized by the political elite, including the President himself. Also, the state lent its structures to the promotion of Church interests that have an international dimension.

The described system corresponds to Robert Putnam's model of two-level games. whereby the state seeks to augment its freedom of action on the international stage by positively affecting its bargaining terms with domestic actors. In the present study, one of the majority actors in society is the Moscow Patriarchate of the Russian Orthodox Church, and it has given vocal support to the state's international policy.

One such policy was to join the Organisation of The Islamic Conference, an organization dedicated to defending Islamic interests worldwide, including to offer support to Muslim minorities. The evidence presented above shows that the Church participated in the 'domestic bargaining' phase of the President's initiative; indeed, its 
ascent in joining an Islamic international organization was noted on several occasions through official oral or written statements, and has sometimes been given more attention than Russia's own Muslim minority's role in bringing about such a development.

The second hypothesis seeks to define whether and how the state reciprocated to the Church's approval for joining an Islamic governmental organization.

$\mathrm{TP}_{2}$ : Socializing with Islamic states within the Organisation of The Islamic Conference has reinforced the Russian state's identification with Russian Orthodoxy.

Whether or not this process takes place in a voluntary and conscious fashion is not truly possible to determine without the use of techniques and theories that go beyond the field of political science into more advanced sociology or psychology. Nonetheless, it would appear that such a process has been taking place within the Russian state and amongst its political elites.

This evidenced by a strengthening of a discourse closely linked with aspects of national identity associated with the Church's historical role in Russian society and statehood. This language is found in presidential Addresses to the Federal Assembly, where he defines and explains his political goals to the central state's legislature. It is possible to establish a link between this discourse and religious Orthodoxy when considering the other statements made by the President on the occasion of formal meetings with Patriarch Aleksy II, where he unambiguously professes the Church's legacy with regards to the preservation of Russian language, culture, and statehood 
itself. As a further element of support to the evidence, the increased frequency of those meetings also needs to be noted.

On the other hand, this closer involvement with an Islamic international organization has not seemed to significantly improve the access of Russian Muslim political or religious leaders to the higher levels of decision-making at the federal level. Moreover, when such contact has occurred, the evidence shows that a defensive posture was adopted by the Muslim leaders. Specifically, they expressed their gratitude to the state for defending their interests, de facto releguing the responsibility of the promotion of their interests to a state whose interests are intertwined with those of the Orthodox Church. That same state has also implicitly distanced itself from its Muslim community by expressing its new association with Islamic states in terms that are dichotomic.

In theoretical terms, this corresponds to findings by Wendt, Greenhill, Corm, Gourevitch, and Hopf regarding the effects of international socialization in general, and specifically with Russia concerning the latter. The current study's results show that Russia has indeed been through a process of redefinition of its identity as a consequence of increased dealings with a perceived 'other', which has in turn affected domestic bargaining with local actors, in this case the Church.

Now, some scholars have either directly posited or inferred that Russia is prone to enter into conflicts with against Islamic states. It is therefore useful to consider how 
Russian foreign policy intersected with that of Islamic counterparts in light of its increased and more open identification with Russian Orthodoxy.

$\mathrm{TP}_{3}$ : This perceived reinforcement of Orthodox identity within the Russian political elite has not precluded the constructive development of international relations with Islamic states.

According to Samuel Huntington's Clash of Civilizations, the very difference of religious belonging should be an intrinsic cause of conflict between two states, and Orthodox and Islamic states should similarly be especially prone to this effect. This assessment was tested in two separate case studies where not only there was an identity difference, but where conflict could have been possible for geopolitical reasons. In other words, a competitive rationale already existed in the selected dyadic relationships. These cases were Russia's relations with the Kingdom of Saudi Arabia and the Islamic Republic of Iran.

Evidence reveals that, even in a context where Russia engaged on a trajectory of stronger Orthodox self-identification, and where the Islamic states studied both were proponents of a radical form of Islam (even if the strain of Islam they represented was fundamentally different), conflict has not broken out.

In the first case, that of Saudi Arabia, it is possible to conclude that Russia was able to assert its interests with regards to its territorial integrity and achieve some degree of political control over a separatist republic by engaging in a partnership with one of its possible arch-enemies in the conflict. It has done so while knowing that this new partner had little room for manoeuvre when it came to suppress elements that formed part of the insurgency it was fighting without risking its own survival as a state. 
Instead, compromise solutions were reached that could serve both the Russian Federation's domestic needs (accommodation of the Muslim minorities, craft a political solution to the conflict in Chechnya acceptable to those minorities) and Saudi Arabia's need to represent the interests of Muslims everywhere, if not as a matter of principle, at least of regime and state survival. In this sense, one could say that religion and other factors of identity became a reason for consensus and collaboration and not conflict between those two states.

As for Russia's policy towards Iran, the picture is more muddled. There are few signs that the two countries are enjoying overtly bad or good relations, but these relations nevertheless exist and are extensive. It appeared, in the course of the study, that little is discussed in Russian-Iranian relations that have a direct impact on internal affairs of the Russian Federation, but rather that the interests that are pursued by Russia are almost wholly situated within the paradigm of international politics. This might be a reason for which factors of identity did not play a demonstrable role in the relations, and therefore could not have caused conflict.

On both counts, however, it is not truly possible, for the same reasons as those discussed in the interlude with regards to the Muslim minorities in Russia, to ascertain the sincerity of the Russian discourse towards both Saudi Arabia and Iran, or, in other words, how the Russian Government perceives its own relations with these two countries. For this reason, and also because both the poststructuralist (real perceptions of foreign policy remain undisclosed due to hidden discourse that is impossible to verify) and the constructivist (open-ended outcomes of international relations) 
ontologies do not make normative assumptions about outcomes, so there will be none made here. It will be left to the reader to infer those normative assumptions from his/her own comprehension of the observations made and theoretical links established, and suggest prescriptions/a course of action to be taken according to their own social situation (public official, scholar, or citizen).

Setting ethics aside, the findings in the previous case studies permit to draw a number of general conclusions about Russian foreign policy. Only that way is it possible to reach a more accurate assessment of its quality, instead of judging it according to whether it is right or wrong, inimical to Western goals or according to its success rate. This often leads to oversimplifications about a country that is anything but.

What counts is the ulterior motive aimed at by the policy and the means by which it is achieved. The constatation is that of a country whose foreign policy has evolved a lot in ten years. While not always successful or even easy to decipher, it has shown a tremendous capacity for the avoidance of conflict, or even cooperation, and that even in situations where engagement was not necessarily evident. One of the ways it does so is by using policy tools in the right situations, and that is what this study has evaluated with regards to religion and identity. Therefore, it can be said to be more sophisticated that what Western countries usually consider it to be, at least with regards to its relations with Saudi Arabia and Iran in the first decade of the twenty-first century.

Focused on the use of identity and religion in Russian foreign policy, the results of this study open up questions about the definition and conceptualization of Russian 
soft power. This theory was not included in the current study for reasons of scope and the already staggering number of variables, but could nevertheless contribute new knowledge about Russian foreign policy.

Also, this study has concentrated on Russia's relations with Islamic countries. However, it has become apparent, while conducting documentary research, that further case studies could be considered to refine the findings of this study, with regards to both depth (more issues per country) and breadth (more countries studied), and that outside of the limits of the Islamic world. It would seem that many countries in Russia's immediate surroundings or general vicinity, could provide interesting and relevant case studies, such as Turkey, Azerbaijan, and Armenia.

Finally, the exact role of the Moscow Patriarchate in Russian foreign policy probably could be more thoroughly investigated, pending the availability of more primary sources. For the time being, it is very probable that the Moscow Patriarchate has played a role, even if indirect, in the formulation and execution of Russian foreign through the influence of domestic bargaining. Dmitry Medvedev, who is Russia's president at the time of this writing, has made direct comments with regards to spirituality guiding the state's international actions in his first Address to the Federal Assembly, leading one to believe that the Church's role in Russian socio-political life has not ended by Vladimir Putin's departure from the presidency (only to assume the prime ministership) and Patriarch Aleksy II's death in 2008. 


\section{Bibliography}

Primary Sources

Ivanov, Igor S. The New Russian Diplomacy. Washington, D.C.: Brookings Institution Press, 2002.

Ivanov, Sergei. "Speech at the 39th Munich Conference on Security Policy." $39^{\text {th }}$ Munich Conference on Security Policy, 2003, www.securityconference.de, last viewed on 1 August 2008.

Ivanov, Sergei. "Speech at the 42nd Munich Conference on Security Policy." $42^{\text {nd }}$ Munich Conference on Security Policy, 2006, www.securityconference.de, last viewed on 1 August 2008 .

Ivanov, Sergei. "Where is Russia heading? New Vision of Pan-European Security." $44^{\text {th }}$ Munich Conference on Security Policy, 2008, Www.securityconference.de, last viewed on 1 August 2008.

Putin, Vladimir. "Speech at the 43rd Munich Conference on Security Policy." 43rd Munich Conference on Security Policy, 2007, www.securityconference.de, last viewed on 1 April 2008.

Saudi MFA. The Foreign Policy of the Kingdom of Saudi Arabia. Riyadh: The Ministry of Foreign Affairs of the Kingdom of Saudi Arabia, 2005. www.mofa.gov.sa, last viewed on 12 August 2010.

Кремль. Послание Федеральному Собранию Российской Федерации. Москва: Президент России: Официальный Сайт, 3 April 2001, http://archive.kremlin.ru/text/appears/2001/04/28514.shtml, last viewed on 31 July 2010.

Кремль. Послание Федеральному Собранию Российской Федерации. Москва: Президент России: Официальный Сайт, 18 April 2002, http://archive.kremlin.ru/text/appears/2002/04/28876.shtml, last viewed on 31 July 2010.

Кремль. Послание Федеральному Собранию Российской Федерации. Москва: Президент России: Официальный Сайт, 16 May 2003, http:/archive.kremlin.ru/text/appears/2003/05/44263.shtml, last viewed on 31 July 2010.

Кремль. Послание Федеральному Собранию Российской Федерации. Москва: Президент России: Официальный Сайт, 26 May 2004, http://archive.kremlin.ru/text/appears/2004/05/71051.shtml, last viewed on 31 July 2010.

Кремль. Послание Федеральному Собранию Российской федерации. Москва: Президент России: Официальный Сайт, 25 April 2005, 
http://archive.kremlin.ru/text/appears/2005/04/87049.shtml, last viewed on 31 July 2010.

Кремль. Послание Федеральному Собранию Российской Федерации. Москва: Президент России: Официальный Сайт, 10 May 2006, http://archive.kremlin.ru/text/appears/2006/05/105546.shtml, last viewed on 31 July 2010.

Кремль. Послание федеральному Собранию Российской федерации. Москва: Президент России: Официальный Сайт, 26 April 2007, http://archive.kremlin.ru/text/appears/2007/04/125339.shtml, last viewed on 31 July 2010.

Кремль. Послание Федеральному Собранию Российской Федерации. Москва: Президент России: Официальный Сайт, 5 November 2008, news.kremlin.ru/transcripts/1968/print, last viewed on 21 August 2010.

Кремль. Встреча с Патриархом Московским и всея Руси Алексием II. Ново-Огарево: Президент России: Официальный Сайт, 15 October 2003, http:/archive.kremlin.ru/text/appears/2003/10/54068.shtml, last viewed on 31 July 2010.

Кремль. Выступление на $X$ встрече глав государств и правительтв Организация Исламская Конференция. Путраджайя: Президент России: Официальный Сайт, 16 October 2003, http://archive.kremlin.ru/text/appears/2003/10/54103.shtml, last viewed on 31 July 2010 .

Кремль. Беседа с Патриархом Московским и всея Руси Алексием II, ПатриархомКатоликосом всея Грузии Илией //, Католикосом всех армян Гагерином // и главой мусульман Кавказа шейх-уль-ислам Аллахшукрюром Паша-заде. Ново-Огарево: Президент России: Официальный Сайт, 26 November 2003, http://archive.kremlin.ru/text/appears/2003/11/56330.5html, last viewed on 31 July 2010.

Кремль. Выступление на встрече с иерархами Русской православной церкви по случаю 90-летия восстановления патриаршества. Москва: Президент России: Официальный Сайт, 19 November 2007, http://archive.kremlin.ru/text/appears/2007/11/151540.shmt, last viewed 31 July 2010.

Кремль. Выступление на торжественном приеме по случаю восстановления единства Русской православной церкви. Москва: Президеит России: Официальный Сайт, 19 May 2007, hito:/archive.kremlin.ru/text/appears/2007/05/129742.shtml, last viewed on 31 July 2010.

Кремль. Вступительное слово на заседании Совета Безопасности по вопросу о ходе антитеррористической операции на Северном Кавказе и налаживания мирной жизни в Чеченской Республике. Москва: Президент России: Официальный Сайт, 25 February 2000, http://archive.kremlin.ru/text/appears/2000/02/122117.shtml, last viewed on 31 July 2010.

Кремль. Выступление на встрече с председателями деловых кругов Саудовской Аравии. Эр-Рияд: Президент России: Официальный Сайт, 12 February 2007, http://archive.kremlin.ru/text/appears/2007/02/118205.shtml, last viewed on 31 July 2010. 
Кремль. Начало встречи с министром иностранных дел Саудовской Аравии принцем Саудом аль-Фейсалом. Москва: Президент России: Официальный Сайт, 25 July 2006, http://archive.kremlin.ru/text/appears/2006/07/109336.shtml, last viewed on 31 July 2010.

Кремль. Начало встречи с Президентом Ирана Махмудом Ахмадинежадом. Шанхай: Президент России: Официальный Сайт, 15 June 2006, http.//archive.kremlin.ru/text/appears/2006/06/107145.shtml, last viewed on 31 July 2010.

Кремль. Выступительное слово на встрече с секретарем Высшего совета национальной безопасности Ирана Хасаном Роухани. Москва: Президент России: Официальный Сайт, $10 \quad$ November 2003, http.//archive kremlin.ru/text/appears/2003/11/55298.shtml, last viewed on 31 July 2010.

Кремль. Интервью Иранскому гостелерадио и информационному агенству ИРНА. Тегеран: Президент России: Официальный Сайт, 16 October 2007, http://archive.kremin.ru/text/appears/2007/10/148471.shtml, last viewed on 31 July 2010.

Кремль. Начало встречи с министром иностранных дел Ирана Камалем Харрази. Москва: Президент России: Официальный Сайт, 17 May 2004, http://archive.kremlin.ru/text/appears/2004/05/64514.shtml, last viewed on 31 July 2010.

Кремль. Начало встречи с секретарем Высшего совета национальной безопасности Ирана Хасаном Роухани. Москва: Президент России: Официальный Сайт, 18 February 2005, http://archive.kremlin.ru/text/appears/2005/02/84192.shtml, last viewed on 31 July 2010.

Кремль. Выступление на открытии Всемирного саммита религиозных лидеров. Москва: Президент России: Официальный Сайт, 3 July 2006, http.//archive.kremlin.ru/text/appears/2006/07/108152.shtml, last viewed on 31 July 2010.

Кремль. Начало встречи с духовными лидерами мусульманских сообществ. Москва: Президент России: Официальный Сайт, 8 November 2007, http:/archive.kremlin.ru/text/appears/2007/11/150774.shtml, last viewed on 31 July 2010.

Кремль. Начало встречи с лидерами мусульманских организаций России. Москва: Президент России: Официальный Сайт, 10 January 2006, http./archive.kremlin.ru/text/appears/2006/01/100096.shtml, last viewed on 31 July 2010.

Кремль. Начало встречи с Патриархом Московским и всея Руси Алексием II. Москва: Президент России: Официальный Сайт, 23 February 2006, htto.//archive.kremlin.ru/text/appears/2006/02/102216.shtml, last viewed on 31 July 2010.

Кремль. Начало встречи с Патриархом Московским и всея Руси Алексием II. Москва: Президент России: Официальный Сайт, 11 June 2004, 
http.//archive.kremlin.ru/text/appears/2004/06/72502.shiml, last viewed on 10 August 2010.

Кремль. Начало встречи с Патриархом Московским и всея Руси Алексием II. Переделкино: Президент России: Официальный Сайт, 13 August 2004, http://archive.kremlin.ru/text/appears/2004/08/75417.shtml, last viewed on 10 August 2010.

Кремль. Начало встречи с Патриархом Московским и всея Руси Алексием II. НовоОгарево: Президент России: Официальный Сайт, 19 April 2006, http://archive.kremlin.ru/text/appears/2006/04/104699.5html, last viewed on 31 July 2010.

Кремль. Начало встречи с Патриархом Московским и всея Руси Алексием II. НовоОгарево: Президент России: Официальный Сайт, 10 June 2006, http./archive.kremlin.ru/text/appears/2006/06/89353.shtml, last viewed on 10 August 2010.

Кремль. Начало встречи с Патриархом Московским и всея Руси Алексием II в связи $45-$ летием его архиерейской хиротонин. Москва: Президент России: Официальный Сайт, 16 September 2006, htto://archive.kremlin.ru/text/appears/2006/09/110561.shtml, last viewed on 10 August 2010.

Кремль. Встреча с Патриархом Московским и всея Руси Алексием II. Москва: Президент России: Официальный Сайт, 6 January 2005, http://archive.kremlin.ru/text/appears/2005/01/82283.shtml, last viewed on 10 August 2010.

Кремль. Начало встречи с Председателем Совета муфтиев России Равилем Гайнутдином. Москва: Президент России: Официальный Сайт, 26 Мау 2004, http.//archive.kremlin.ru/text/appears/2004/05/64904.5html, last viewed on 31 July 2010.

Кремль. Выдержки из беседы с председателями делегаций III съезда Всемирного конгресса татар. Казань: Президент России: Официальный Сайт, 30 August 2002, http://archive kremlin.ru/text/appears/2002/08/29318.shtml, last viewed on 10 August 2010.

Кремль. Выдержки из стенографического отчета о заседании Государственного совета по проблемам внешней политики России. Москва: Президент России: Официальный Сайт, 22 January 2002, http.//archive.kremlin.ru/text/appears/2002/01/151850.shtml, last viewed on 10 August 2010.

МИД России. Концепция национальной безопасности Российской Федерации. Москва: Министерство иностранных дел Российской Федерации, 10 January 2000, www.mid.ru, last viewed on 30 March 2009.

МИД России. Интервью Министра иностранных дел России И.С. Иванова, опубликованное в газете "Московский комсомолец" 5 декабря 2003 года под заголовком “За эти годы мы не ухудшили отношения ни с одной страной." Москва: Министерство иностранных дел Российской федерации, 5 December 2003, www.mid.ru, last viewed 12 August 2010. 
МИД России. Заключительное слово Президента России В.В. Путина по окончании переговоров с Наследным принцем Королества Саудовская Аравия Абдаллой Бен Абдель Азиза Аль Сауда, Москва, Кремль, 2 сентября 2003 года. Москва: Министерство иностранных дел Российской федерации, 3 September 2003, www.mid.ru, last viewed on 12 August 2010.

МИД России. Об итогах переговоров Президента России и Наследного принца Саудовской Аравии Абдаллы. Москва: Министерство иностранных дел Российской федерации, 3 September 2003, www.mid.ru, last viewed on 12 August 2010.

МИД России. Стенограмма выступления Министра иностранных дел России И.С. Иванова на совместной пресс-конференции по итогам переговоров С Министром иностранных дел С.А. С. аль-Фейсалом, Москва, 8 мая 2003 года. Москва: Министерство иностранных дел Российской федерации, 12 Мау 2003, www.mid.ru, last viewed on 12 August 2010.

МИД России. Ответы официального представителя МИД России А.В. Яковенко на вопросы российских СМИ в связи С предстоящим визитом в Москву министра иностранных дел Саудовской Аравии С. аль-фейсала. Москва: Министерство иностранных дел Российской федерации, 8 May 2003, www.mid.ru, last viewed on 12 August 2010.

МИД России. Об итогах заседания российско-саудовской Межправкомиссии по двустороннему сотрудничеству. Москва: Министерство иностранных дел Российской федерации, 16 October 2003, www.mid.ru, last viewed on 12 August 2010.

МИД России. Стенограмма выступления Министра иностранных дел России И.С. Иванова на совместной пресс-конференции с Министром иностранных дел С.А. Саудом Аль-Фейсалом по итогам переговоров, состоявшихся 3 сентября 2003 года. Москва: Министерство иностранных дел Российской федерации, 3 September 2003, www. mid.ru, last viewed 12 August 2010.

МИД России. Интервью директора Второго департамента Азии МИД России А.Г. Марьясова службе внешнеполитической информации ИТАР-ТАСС 5 апреля 2007 года. Москва: Министерство иностранных дел Российской федерации, 6 April 2007, www.mid.ru, last viewed on 18 August 2010.

МИД России. Ядерная программа Ирана: позиция России. Москва: Министерство иностранных дел Российской федерации, 19 July 2005, www.mid.ru, last viewed on 18 August 2010.

МИД России. Ответ официального представителя МИД России М.А. Камынина на вопрос российских СМИ в связи с ситуацией вокруг иранской ядерной программы. Москва: Министерство иностранных дел Российской федерации, 17 August 2005, www.mid.ru, last viewed on 18 August 2010.

МИД России. Заявление Министров иностранных дел Китая, Франции, Германии, России, Великобритании и США при поддержке Высокого представителя Европейского союза. Москва: Министерство иностранных дел Российской федерации, 28 September 2007, www.mid.ru, last viewed on 18 August 2010.

МИД России. Стенограмма выступления Министра иностранных дел России С.В.Лаврова перед СМИ по итогам поездки в Иран, Тегеран, 30 октября 2007 
года. Москва: Министерство иностранных дел Российской федерации, 31 October 2007, www. mid.ru, last viewed on 18 August 2010.

МИД России. Совместное Российско-Саудовское заявление, 4 сентября 2003 года. Москва: Министерство иностранных дел Российской федерации, 5 September 2003, www. mid.ru, last viewed on 12 August 2010.

МИД России. Заявление министров иностранных дел Китая, Франции, Германии, Соединенного Королевства Великобритании и Северной Ирландии и Соединенных Штатов Америки при поддержке Высокого Представителя Европейского Союза в связи с принятием резолюции Совета Безопасности ООН. Москва: Министерство иностранных дел Российской Федерации, 25 March 2007, www.mid.ru, last viewed on 18 August 2010.

МИД России. Комментарий Департамента информации и печати МИД России в связи с вопросами агентств "ИТАР-ТАСС" и "Интерфакс" относительно заявления иранской стороны о том, что "резолюция СБ ООН по Ирану не имеет под собой правовых оснований." Москва: Министерство иностранных дел Российской Федерации, 8 March 2006, wmw.mid.ru, last viewed on 18 August 2010.

МИД России. Ответ официального представителя МИД России М.Л.Камынина на вопрос СМИ в связи с заявлением Президента Ирана о начале производства в Иране ядерного топлива в промышленных масштабах. Москва: Министерство иностранных дел Российской Федерации, 4 October 2007, wmw.mid.ru, last viewed on 18 August 2010.

МИД России. Стенограмма выступления Министра иностранных дел России С.В.Лаврова на пресс-конференции по итогам переговоров с Министром иностранных дел Ирана М.Моттаки, Москва, 24 октября 2005 года. Москва: Министерство иностранных дел Российской Федерации, 24 October 2005, www.mid.ru, last viewed on 18 August 2010.

МИД России. Ответ официального представителя МиД России М.Л.Камынина на вопрос российских информационных агентств о докладе Генерального директора МАГАТЭ М.Эль-Барадея по иранской ядерной программе. Москва: Министерство иностранных дел Российской Федерации, 24 Мау 2007, www.mid.ru, last viewed on 18 August 2010.

МИД России. Выступление Министра иностранных дел России С.В.Лаврова на 32-й Конференции министров иностранных дел стран-членов ОИК, Сана, 29 июня 2005 года. Москва: Министерство иностранных дел Российской Федерации, 1465-29-06-2004 (sic), www.mid.ru, last viewed on 24 January 2009.

МИД России. Ответы официального представителя МИД России А.В.Яковенко на вопросы российских СМИ в связи с визитом Министра иностранных дел России С.В.Лаврова в Йемен и его участием в 32-ой Конференции мининдел ОИК. Москва: Министерство иностранных дел Российской Федерации, 1462-29-062005, www. mid.ru, last viewed on 24 January 2009.

МИД России. Ответы официального представителя МИД России А.В.Яковенко на вопросы российских СМИ относительно сотрудничества России с Организацией исламская конференция. Москва: Министерство иностранных дел Российской Федерации, 1484-01-07-2005, last viewed on 24 January 2009. 
МИД России. Заявление Министерства иностранных дел Российской Федерации в связи с объявлением о предтавлении России статуса наблюдателя в ОИК. Москва: Министерство иностранных дел Российской Федерации, 1487-02-07-2005, www. mid.ru, last viewed on 24 January 2009.

МИД России. О втрече Президента России В.В.Путина с генеральным секретарем Организации исламская конференция (ОИК) Э.Ихсаноглу, Москва, 7 июня 2006 года. Москва: Министерство иностранных дел Российской Федерации, 08-062006, www. mid.ru, last viewed on 24 January 2009.

МИД России. Ответ официального представителя МИД России М.Л.Камынина на вопрос РИА «Новости» в связи с предстоящим участием Министра иностранных дел России С.В.Лаврова в ХI встрече в верхах Организации исламская конференция. Москва: Министерство иностранных дел Российской Федерации, 315-11-03-2008, www.mid.ru, last viewed on 24 January 2009.

МИД России. Российско-саудовские отношения (справочная информация). Москва: Министерство иностранных дел Российской Федерации, 26-05-2008, www.mid.ru, last viewed on 10 March 2009.

МИД России. О торгово-экономическом сотрудничестве с Исламской Республикой Иран (справочная информация). Москва: Министерство иностранных дел Российской Федерации, 02-03-2009, www.mid.ru, last viewed on 10 March 2009.

МИД России. Российско-иранские отношения (справочная информация). Москва: Министерство иностранных дел Российской Федерации, 02-03-2008, Www. mid.ru, last viewed on 10 March 2009.

МИД России. Статья посла по особым поручениям МИД России В.В. Попова "Между Западом и исламским миром", опубликованная в "Российской газете" 18 апреля 2007 года. Москва: Министерство иностранных дел Российской Федерации, 18 April 2007, www.mid.ru, last viewed on 24 January 2009.

МИД России. Заключительное коммюнике первой встречи Группы “Стратегическое видение: Россия - исламский мир", 27-28 марта 2006. Москва: Министерство иностранных дел Российской Федерации, 31-03-2006, www.mid.ru, last viewed on 24 January 2009.

МИД России. Интервью Министра Иностранных дел России С.в. Лаврова, опубликованное в арабском журнале "Аль-Ватан Аль-Араби." Москва: Министерство иностранных дел Российской Федерации, 29 June 2005, www.mid.ru, last viewed on 24 January 2009.

МИД России. Материалы второго заседания группы стратегического видения "Россия исламский мир", Казань, 29-31 августа 2006 года. Москва: Министерство иностранных дел Российской Федерации, 6 September 2006, www.mid.ru, last viewed on 24 January 2009.

РПЦ. «Международные отношения. Проблемы глобализации и секуляризма.» Основы социальной концепции Русской Православной Церкви, Official Website of the Moscow Patriarchate, http / www.mospat.ru/center. php?mid=196?newwin=1\&prn=1, last viewed on 24 January 2009. 

РПЦ. «Церковь и нация.» Основы социальной концепции Русской Православной Церкви, Official Website of the Moscow Patriarchate, http:// www.mospat.ru/center.php?mid=182?newwin=1\&prn=1, last viewed on 24 January 2009.

РПЦ. «Церковь и политика.» Основы социальной концепции Русской Православной Церкви, Official Website of the Moscow Patriarchate, http://www.mospat.ru/, last viewed on 24 January 2009.

РПЦ. «Церковь и государство.» Основы социальной концепции Русской Православной Церкви, Official Website of the Moscow Patriarchate, http://www. mospat.ru/center.php?mid $=183$ ?newwin $=1 \&$ prn $=1$, last viewed on 24 January 2009.

\section{Secondary Sources}

Agadjanian, Alexander. "Public Religion and the Quest for National Ideology: Russia's Media Discourse." Journal for the Scientific Study of Religion 40, no. 3 (2001): 351365.

Agger, Ben. "Critical Theory, Poststructuralism, Postmodernism: Their Sociological Relevance." Annual Review of Sociology 17 (1991): 105-131.

Anderson, John. "Putin and the Russian Orthodox Church: Asymmetric Symphonia?" Journal of International Affairs 61, no. 1 (Fall/Winter 2007): 185-201.

Aydin, Mustafa. "Oil, Pipelines and Security: The Geopolitics of the Caspian Region." in Moshe Gammer (ed.), The Caspian Region: A re-emerging region, Volume I, London and New York: Routledge, 2004, 3-31.

Battistella, Dario. Théories des Relations internationales. Paris: Presses de Sciences Po, 2003.

Battistella, Dario. Théories des Relations internationales. Paris: Presses de Sciences Po, 2006.

Battistella, Dario. "L'intérêt national. Une notion, trois discours." Chârillon, François (dir.). Politique étrangère: Nouveaux regards. Paris : Presses de Science Po, 2005, pp. 139166.

Baudoin, Marie-Elisabeth. "Is the Constitutional Court the Last Bastion in Russia Against the Threat of Authoritarianism?" Europe-Asia Studies 58, no. 5 (Jul 2006): 679-699.

Bendersky, Yevgeny. "Russia and Its Muslim Population: A Balancing Act." Power and Interest News Report, 10 September 2004, www.pinr.com, last viewed on 22 January 2009. 
Bendersky, Yevgeny. "Russia's Future Foreign Policy: Pragmatism in Motion." Power and Interest News Report, 2007, www.pinr.com, last viewed on 26 September 2007.

Berti, Benedetta. "Iran Strengthens its Role in the Caspian Sea and Central Asian Regions." Power and Interest News Report, 6 November 2007, www.pinr.com, last viewed on 22 January 2009.

Billings, Dwight B., and Shaunna L. Scott, "Religion and Political Legitimation." Annual Review of Sociology 20, (1994): 173-202.

Blagov, Sergei. "Putin Aims for Higher Russian Profile." Power and Interest News Report, 26 January 2004, www.pinr.com, last viewed on 22 January 2009.

Bordonaro, Federico. "Georgia-Russia Missile Row Calls for the West to Revise its Strategy in Eurasia." Power and Interest News Report, 22 August 2007, www.pinr.com, last viewed on 22 January 2009.

Bourdeaux, Michael. "The religious maelstrom of modern Russia." The Times (8 July 2006) www.timesonline.co.uk (last viewed 24 August 2010).

Bremer, Thomas. Kreuz und Kreml: Kleine Geschichte der orthodoxen Kirche in Russland. Freiburg: Herder-Verlag, 2007.

Bugajski, Janusz. Cold Peace: Russia's New Imperialism. Washington, D.C.: Center for Strategic and International Studies, 2006.

Carlsnaes, Walter. "The Agency-Structure Problem in Foreign Policy Analysis." International Studies Quarterly 36, no. 3 (Sept 1992): 245-270.

Campbell, David. "Poststructuralism", in Tim Dunne, Milja Kurki and Steve Smith, International Relations Theories: Discipline and Diversity. Oxford: Oxford University Press, 2007, 203-228.

Commins David. The Wahhabi Mission and Saudi Arabia. London: I B Tauris and Co Ltd, 2009.

Cordesman, Anthony H. Saudi Arabia Enters the Twenty-First Century: The Political, Foreign Policy, Economic, and Energy Dimensions. Westport: Praeger, 2003.

Corm, Georges. La question religieuse au XXIe siècle: Géopolitique et crise de la postmodernité. Paris: La Découverte, 2006.

Corso, Molly. "Georgian-Russian Relations Continue to Deteriorate." Power and Interest News Report, 7 December 2005, www. pinr.com, last viewed on 22 January 2009.

Cristiana, Dario. "Russia's New Initiatives in the Persian Gulf." Power and Interest News Report, 1 March 2007, www.pinr.com, last viewed 15 March 2009. 
De Haas, Marcel. "Current Geostrategy in the South Caucasus." Power and Interest News Report, 15 December 2006, www.pinr.com, last viewed on 22 January 2009.

De Haas, Marcel. "S.C.O. Summit Demonstrates Its Growing Cohesion." Power and Interest News Report, 14 August 2007, www.pinr.com, last viewed on 22 January 2009.

Derrida, Jacques. De la grammatologie. Paris: Les Éditions de Minuit, 1967.

Ehteshami, Anoushiravan. "The Foreign Policy of Iran," in Hinnebush, Raymond and Anoushiravan Ehteshami (eds.). The Foreign Policies of Middle East States. Boulder: Lynne Rienner Publishers Inc., 2002, pp. 283-310.

Evangelista, Matthew. The Chechen Wars: Will Russia Go the Way of the Soviet Union? Washington, D.C.: Brookings Institution Press, 2002.

Fatah, Tarek. Chasing a Mirage: The Tragic Illusion of an Islamic State. Toronto: Wiley, 2008.

Ferguson, Kennan. "Unmapping and Remapping the World: Foreign Policy as Aesthetic Practice", in Michael J. Shapiro and Hayward R. Alker (eds.). Challenging Boundaries: Global Flows, Territorial Identities. Minneapolis: University of Minnesota Press, 1996, 165-191.

Foucault, Michel. L'archéologie du savoir. Paris: Éditions Gallimard, 1969.

Foucault, Michel. Surveiller et punir. Paris: Éditions Gallimard, 1975.

Garrard, John, and Carol Garrard. Russian Orthodoxy Resurgent: Faith and Power in the New Russia, Princeton: Princeton University Press, 2008.

Gause III, F. Gregory. "The Foreign Policy of Saudi Arabia," in Hinnebush, Raymond and Anoushiravan Ehteshami (eds.). The Foreign Policies of Middle East States. Boulder: Lynne Rienner Publishers Inc., 2002, 193-212.

Gel'man, Vladimir. "Party Politics in Russia: From Competition to Hierarchy." EuropeAsia Studies 60, no. 6 (Aug 2008): 913-930.

Gourevitch, Peter. "The Second Image Reversed: The International Sources of Domestic Politics." International Organization 32, no. 4 (1978): 881-912.

Greenhill, Brian. "Recognition and Collective Identity Formation in International Politics." European Journal of International Relations 14, no. 2 (2008): 343-368.

Gresh, Alain. "Russia's Return to the Middle East." Journal of Palestine Studies 28, no. 1 (1998): 67-77. 
Greeley, Andrew. "A Religious Revival in Russia?" Journal for the Scientific Study of Religion 33, no. 3 (1994): 253-272.

Hale, Henry E. "Yabloko and the Challenge of Building a Liberal Party in Russia." EuropeAsia Studies 56, no. 7 (Nov 2004): 993-1020.

Hansen, Flemming S. "Islam in Russian Security Concerns." in Moshe Gammer (ed.), The Caspian Region: A Re-Emerging Region, Volume I, New York and London: Routledge, 2004, 55-72.

Hansen, Lene. Security as Practice: Discourse Analysis and the Bosnian War. New York: Routledge, 2006.

Hanson, Eric O. Religion and Politics in the International System Today. Cambridge: Cambridge University Press, 2006.

Haynes, Jeff. Religion in Global Politics. London and New York: Longman, 1998.

Herzfeld, Michael. «La revanche de la communauté locale: la globalisation de l'hétérogénéité locale. » Elbaz, Mikhaël, and Denise Helly (dir.). Mondialisation, citoyenneté et multiculturalisme. Québec: Les Presses de l'Université Laval, 2000, pp. 69-78.

Holsti Ole R. "Models of International Relations and Foreign Policy." Diplomatic History 13 no. 1 (1959): 15-43.

Hopf, Ted. "Identity, legitimacy, and the use of military force: Russia's Great Power Identities and military intervention in Abkhazia." Review of International Studies 31 (2005): 225-243.

Hudson, Valerie M., and Christopher S. Vore. "Foreign Policy Analysis Yesterday, Today, Tomorrow." Mershon International Studies Review 39, no. 2 (Oct 1995): 209-238.

Hunter, Shireen T. Islam in Russia: The Politics of Identity and Security. London: M.E. Sharpe, 2004.

Huntington, Samuel P. The Clash of Civilizations and the Remaking of World Order. New York: Simon \& Schuster, 2003.

Keddie, Nikki R. Modern Iran: Roots and Results of Revolution. New Haven and London: Yale University Press, 2006.

Kessler, Marie-Christine. «La politique étrangère comme politique publique.» Chârillon, Frédéric (dir.). Politique étrangère: Nouveaux regards. Paris: Presses de Sciences Po, 2002, pp. 167-192. 
Knox, Zoe. "Russian Orthodoxy, Russian Nationalism, and Patriarch Aleksii II." Nationalities Paper 33, no. 4 (December 2005): 533-545.

Kramer, Andrew E. "Russia Sets Date for Crucial Step in Iranian Nuclear Start-Up." The New York Times (13 August 2010), www.nytimes.com, last viewed on 15 August 2010.

Levy, Clifford J. "Russia Says Sanctions Against Iran Are Unlikely." New York Times (11 September 2009) www.nytimes.com, last viewed on 12 September 2009.

Lukyanov, Fyodor. "Time for a New Foreign Policy Look." The Moscow Times, 28 December 2006, http:/www.moscowtimes.ru/stories/2006/12/28/006.htm1, last viewed on 28 December 2006.

Lynch, Allan C. "The Realism of Russia's Foreign Policy." Europe-Asia Studies 53, no. 1 (2001): 7-31.

McFaul, Michael. "A Precarious Peace: Domestic Politics in the Making of Russian Foreign Policy." International Security 22, no. 3 (1998): 5-35.

McLeod, Alex. «L'approche constructiviste de la politique étrangère.» Chârillon, Frédéric (dir.). Politique étrangère: Nouveaux regards. Paris: Presses de Sciences Po, 2002, pp. 65-90.

Mendeloff, David. “'Pernicious History' as a Cause of National Misconceptions: Russia and the 1999 Kosovo War." Cooperation and Conflict 43, no. 1 (2008): 31-56.

Miller, Kent D. "Competitive Strategies of Religious Organizations." Strategic Management Journal 23, no. 5 (2002): 435-456.

Mitrofanova, Anastasia V. The Politicization of Russian Orthodoxy: Actors and Ideas. Stuttgart: ibidem-Verlag, 2005.

Moore, Margaret R. "Liberal Nationalism and National Minorities." Elbaz, Mikhaël, and Denise Helly (dir.). Mondialisation, citoyenneté et multiculturalisme. Québec: Les Presses de 1'Université Laval, 2000, pp. 131-146.

Neumann, Iver B. "The Double Arrival of Russia in International Society: Membership and Great Power Status." International Studies Association Conference, New Orleans, 2002.

Niblock, Tim. Saudi Arabia: Power, Legitimacy and Survival. New York and London: Routledge, 2006.

Niblock, Tim. The Political Economy of Saudi Arabia. New York and London: Routledge, 2007. 
Nonneman, Gerd. "Determinants and Patterns of Saudi Foreign Policy: 'Omnibalancing' and 'Relative Autonomy' in Multiple Environments" in Aarts, Paul, and Gerd Nonneman (ed.). Saudi Arabia in the Balance: Political Economy, Society, Foreign Affairs. New York: New York University Press, 2007, 315-351.

Parker, John W. Persian Dreams: Moscow and Tehran since the Fall of the Shah. Washington, D.C.: Potomac Books, Inc., 2008.

Popescu, Nicu. "Russia's Soft Power Ambitions." CEPS Policy Briefs 1, no. 12 (2006).

Putnam, Robert D. "Diplomacy and Domestic Politics: The Logic of Two-Level Games." International Organization 42, no. 3 (1978): 427-460.

Rancière, Jacques. "Citoyenneté, culture et politique." Elbaz, Mikhaël, and Denise Helly (dir.). Mondialisation, citoyenneté et multiculturalisme. Québec: Les Presses de l'Université Laval, 2000, pp. 55-68.

Riemer, Matthew. "Russia's Newfound Influence." Power and Interest News Report, 2 October 2003, www.pinr.com, last viewed on 22 January 2009.

Riemer, Matthew. "Caspian Region Likely to Remain Critical for Foreseeable Future." Power and Interest News Report, 12 January 2004, www.pinr.com, last viewed on 22 January 2009.

Rosenau, James C. and Mary Durfee. "The Need for Theory", in James N. Rosenau and Mary Durfee (dirs.), Thinking Theory Thoroughly: Coherent Approaches to an Incoherent World. Boulder: Westview Press, 1995, 1-8.

Scott, James C. Domination and the Arts of Resistance: Hidden Transcripts. New Haven: Yale University Press, 1990.

Seul, Jeffrey R. “"Ours is the Way of God': Religion, Identity, and Intergroup Conflict." Journal of Peace Research 36, no. 5 (1999): 553-569.

Shapiro, Michael. Language and Political Understanding. New Haven and London: Yale University Press, 1987.

Sherkat, Darren E. and Christopher G. Ellison. "Recent Developments and Current Controversies in the Sociology of Religion." Annual Review of Sociology 25, (1999): 363-394.

Shevtsova, Lilia. Putin's Russia. Washington, D.C.: Carnegie Endowment for International Peace, 2005.

Shlapentokh, Dmitry. "Islam and Orthodox Russia: From Eurasianism to Islamism." Communist and Post-Communist Studies 41, (2008): 27-46. 
Takeyh, Ray. Hidden Iran: Power and Paradox in the Islamic Republic. New York: Times Books/Henry Holt and Company, 2007.

Trenin, Dmitri. "Russia and Global Security Norms." The Washington Quarterly 27, no. 2 (2004): 63-77.

Tsygankov, Andrei P. "The final triumph of the Pax Americana? Western Intervention in Yugoslavia and Russia's debate on the post-Cold War order." Communist and PostCommunist Studies 34 (2001): 133-156.

Von Twickel, Nikolaus. "In Like a Dove, Out Like a Hawk." The Moscow Times, 22 February 2008, www.moscowtimes.ru, last viewed on 22 February 2008.

Walker, Christopher, and Robert Orttung. "Russia: Putinism's Impact On The Neighbors." Radio Free Europe / Radio Liberty (12 February 2008) www.rforl.org, last viewed on 15 March 2009.

Wendt, Alexander. Social Theory of International Politics. Cambridge: Cambridge University Press, 1999.

White, Stephen K. "Poststructuralism and Political Reflection." Political Theory 16, no. 2 (May 1988): 186-208.

White, Stephen, and Ian McAllister. "Orthodoxy and Political Behavior in Postcommunist Russia." Review of Religious Research 41, no. 3 (2000): 359-372.

Whitmore, Brian. "New Russia Debate Takes Shape." Radio Free Europe/Radio Liberty, 28 October 2007, www.rferl.org, last viewed on 29 October 2007.

Wright, Robin. The Last Great Revolution: Turmoil and Transformation in Iran. New York: Alfred A. Knopf, 2000.

Zelikow, Philip. "Foreign Policy Engineering: From Theory to Practice and Back Again." International Security 18, no. 4 (1994): 143-171.

. "Intelligence Brief: Russia Reasserts Power with Thermobaric Weapons and Bomber Runs." Power and Interest News Report, 2007, www.pinr.com, last viewed on 19 November 2007.

Аврамченко, Руслан. "Обществу нужна массовая церковь: Светская парадигма религиозной культуры." Политический Класс 44 (Август 2008) htı://www politklass.ru/cgi-bin/issue.pl?id=1048, last viewed on 3 October 2008.

Бузгалин, Александр. «Церковь, общество и нравственность: Почему в России разворачивается процесс оцерковления социальной жизни и нравтвенности.» Политический Класс 45 (September 2008) http://www.politklass.ru/cgibin/issue.pl?id =1050, last viewed on 15 March 2009. 
Кагарлицкий, Борис. «Россия в современной миросистеме: новая периферия или фактор перемен?.» Институт Проблем Глобализации, www.iprog.ru, last viewed on 29 August 2003.

Комозин, Александр. «Постоянные и переменные (43).» Политический Класс 43 (Июль 2008) htto://www.politklass.ru/cgi-bin/issue.pl?id=1029, last viewed on 4 August 2008.

Малер, Аркадий. «Рождение Православного Проекта: Универсальные ценности ортодоксального христианства между либеральным Западом и.» (sic) Политический Класс 41 (Май 2008) http://www.politklass.ru/cgibin/issue.pl?id=1007, last viewed on 15 March 2009.

НИГ. 100 политиков России в июне 2010 года. Независимая издательская группа, 20 July 2010, http://www. nigru.ru/docs/9/2561.html, last viewed on 29 July 2010.

Орлова, Василина. «Неорусская доктрина: Церковь представляет проект модернизации для всего государства.» Политический Класс 36, (Январь 2008) http://www.politklass.ru/cgi-bin/issue.pl?id=938, last viewed on 15 March 2009.

Платонов, С.Ф. Лекции по русской истории. Санкт-Петербург: Золотой век, 2004.

Фоменко, Александр. «Геополитика еврославизма.» Политический Класс 42, (Июнь 2008) http://www.politklass.ru/cai-bin/issue.pl?id=1019, last viewed on 13 July 2008.

Шатилов, Александр. «Друзья и враги России-2020: Диапазон возможностей во внешней политике.» Политический Класс 46 (Октябрь 2008) http://www.politklass.ru/cgi-bin/issue.pl?id=1064, last viewed on 15 March 2009.

. "Дума отменяет православную культуру.» Известия, 4 October 2007, http://news.mail.ru/politics/1446436/, last viewed on 4 October 2007.

\section{Presentation Guide}

Turabian, Kate L. A Manual for Writers of Research Papers, Theses, and Dissertations: Chicago Style for Students and Researchers. $7^{\text {th }}$ Edition. Chicago: The University of Chicago Press, 2007. 